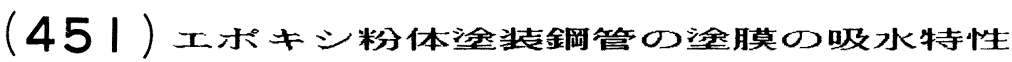

\author{
新日本製鐵湖 君津技術研究部 ○石田雅已 鈴木和幸
}

第二技術研究所 谷川健一 加藤弘忠

\section{1. 緒言}

埋設配管として広く使用されている外面エポキシ粉体塗装鋼管は、塗膜の分子内に函性基を有しているために高温湿潤環境におい て水を吸収して塗膜の機械的性啠および防食性能が低下する䈍念がある。 い塗料を使用すべきであるという指摘があるが、 ${ }^{(2)}$ その場合の高温使用限界は明らかにされていない。そこで、機械的な高温使用限 界の目安として一般に採用されているガラス転移温度（Tg）の吸水による変化を調べた。

2. 㬰験万法

（1）供試材； テフロンコーティングした鋼板にエボキシ粉体塗料を 塗装し、試験に供する分離塗膜を得た。なお、このときの塗膜厚み は360〜440

（2）試験方法； $80^{\circ} \mathrm{C}$ の蒸留水中で吸水させた分離叙膜の吸水率を 测定した後、ただちに動的粘弾性测定機で弾性率の温度変化を测定 した。そして、弾性率が急激に低下しはじめる温度をガラス転移温 度とした。

\section{3. 氠験結果}

（1）塗膜の吸水は、3000時間経過後も飽和に達しない。そして、 現有叙料の中で吸水率がもっとも小さいと言われる塗料でも $4 \%$ 以 上の吸水を示す（F i g . 1)。

（2）吸水した塗膜は、常温域で弾性率が低下するほか、ガラス転移温 度も低下する（F i g ～2 2)。

（3）塗膜のガラス転移温度は吸水とともに急激に低下し、吸水率 $4 \%$

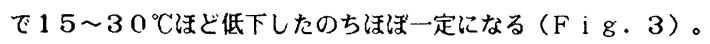
このガラス転移温度の低下は吸収された水の可塑化作用によるもの と言われている。

\section{4. 結言}

外面粉体エポキシ塗装銅管は、塗膜のガラス転移温度が $100^{\circ} \mathrm{C}$ 以上で あるため、高温環境用として通していると思われていた。ところが、現有

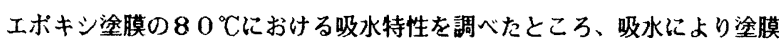
のガラス転移温度が $85 \sim 95^{\circ} \mathrm{C}$ 程度まで低下するので、機械的性質から

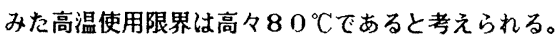

\section{(参考文献)}

(1) V.H.Landgraf: Rohre.Ruhrleit.int.,20 (9) 483 (1981).

(2) K.Omori.et.al.: Proc.5th Pipe Protection, B2,67 (1983).

（3）佐藤：色材協会誌， $\underline{55 （ 6 ） 399 （ 1982 ） . ~}$

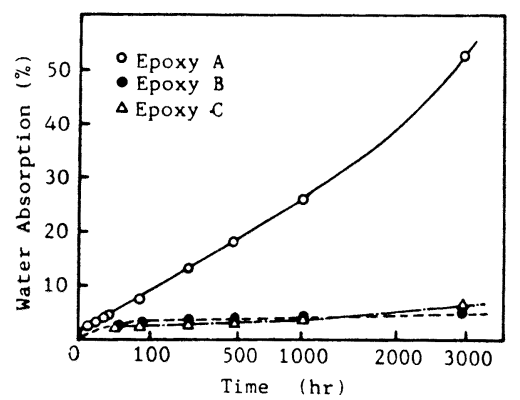

Fig.1 The change of water absorption with

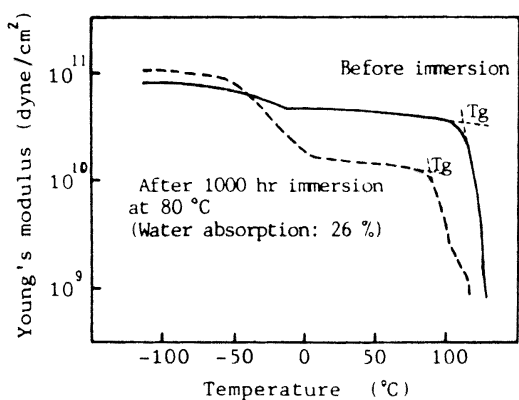

Fig.2 Young's modulus of free films of epoxy A before and after water immersion.

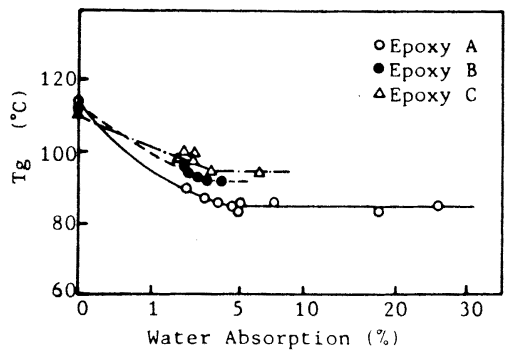

Fig. 3 The change of glass transition temperature of free films with water absorption. 
(452) エポキシ粉体塗装鉄筋の耐食性および塗膜性能

川崎製鉄俐技術研究所 ○大和田哲，栗栖孝雄，中井揚一

\section{1. 粕 言}

鉄筋コンクリート構造物において道路凍結防止用塩散布、骨材としての海砂使用、海洋環境八の適用に際し、 塩害によるコンクリートの少化および鉄筋の腐食が大をな社会問題となっている。本報では、鉄筋の塩害防止対 策としてエポキシ粉体塗装鉄筋について、㓌膜特性およびコンクリート中での耐食性を調べを結果について述べ 万。

\section{2, 実 験}

2.1 供試材

エポキシ勧装鉄筋は素材棒鋼の形状、寸法、下地処理条件、 塗料、塗装条件を変えて製作した。供試材の製作条件を Table 1飞示す。また、コンクリート埋込み試験体はFig.1亿示す形 状、寸法のbの製作し、試蛤に供した。

\section{2 塗膜特性}

エポキシ塗装鉄筋の鉒膜特性として、(1) 整膜性状：外観、硬 度、膜厚、ピンホール、(2)機械的特性：曲げ加工性、耐摩耗性、 酎衝撃性、コンクリートとの付着性につレて調へ、上記特性 の棒銈形状、寸法、下地処理条件、蒤料および涂膜厚さにお よ济す影響につルて検討した。

\section{3 腐食試験}

(1)小試験体暴露試験：コンクリート埋込み試験体（Fig.1） を治岸大気中叔よ゙飛沫带に3 年間自然暴露し、鉄筋の腐食性 およびコンクリートかぶり厚さ、塩分量、ひびわれ、塗膜ピン ホール、クラックなどの影響を調べた。

(2)実構造物試験：巾 $200 \mathrm{~mm} \times$ 長さ $30 \mathrm{~m}$ の防潮堤における D 22 エポキシ叙装鉄筋の 3 年間での耐食性を調べた。

\section{3. 結 果}

(1)塗膜性状：㙦膜は鉛筆硬度 $2 \mathrm{H}$ 以上と硬く、ピンホールも $3 \sim 4$ 個 $/ m$ 以下の良好なるのが得られた。なお、ピンホール は鉄筋フシ部で多く発生した。

(2) 機械的特性：コンクリートの付着性は黒皮鉄筋の $82 \%$ (横 フシ型) 〜 93\%(ネジ型) 以上の值が得られ（Table 2)、曲げ 加工性す6DD 曲げ以上で良好であった。

(3)耐食性： 3 年間の治岸大気、飛沫帯での暴露試験および防 潮堤への適用でエポキシ淦装鉄筋は涂腰劣化、さび発生はなく (Fig. 2) 、ピンホール、クラックの影響もなかった。

\section{4. まとめ}

Table 1 Marrufacturing conditions of test piece

\begin{tabular}{|c|c|c|c|}
\hline \multirow[t]{6}{*}{$\begin{array}{l}\text { epoxy coated } \\
\text { steel bar }\end{array}$} & steel bar & \begin{tabular}{|c|} 
Jis \\
oize \\
knot \\
type
\end{tabular} & $\begin{array}{l}\text { SD } 30(\mathrm{SH} 30) \\
\text { D 13, D 19, D 22, D } 32 \\
\text { lateral, cross, screw } \\
\text { round bar }\end{array}$ \\
\hline & \multicolumn{2}{|c|}{$\begin{array}{l}\text { surface } \\
\text { treatment }\end{array}$} & $\begin{array}{l}\text { (1) blesting (shot, grid) } \\
70,100 \\
\text { (2) pickling ( HC1) } \\
\text { (3) chenical treutment }\end{array}$ \\
\hline & \multirow{2}{*}{\multicolumn{2}{|c|}{ coating material }} & 6 kinds of epoxy resin \\
\hline & & & $140 \sim 230^{\circ} \mathrm{C}$ \\
\hline & \multicolumn{2}{|c|}{ coating voltage } & $70 \mathrm{kV}$ \\
\hline & \multicolumn{2}{|c|}{ coating thickness } & $100,200,300 \mu \mathrm{m}$ \\
\hline \multirow[t]{4}{*}{$\begin{array}{l}\text { concrete block } \\
\text { test piece }\end{array}$} & \multicolumn{2}{|c|}{ steel bar } & $\begin{array}{l}\text { D } 13 \text { epoxy coated steel bar } \\
\text { with and without p1rhole, creck } \\
\text { D } 13 \text { no-coated steel bar }\end{array}$ \\
\hline & \multicolumn{2}{|c|}{$\begin{array}{l}\text { covering thickness } \\
\text { of concrete }\end{array}$} & $15,30,50 \mathrm{~cm}$ \\
\hline & \multicolumn{2}{|c|}{$\begin{array}{l}\text { salt content in } \\
\text { concrete }\end{array}$} & $0,0.4 \quad$ (wt $*$ as $\mathrm{NaCl} 1$ ) \\
\hline & \multicolumn{2}{|c|}{ crack of concrete } & wi thout crack, $0.2 \mathrm{~mm}$ width crack \\
\hline
\end{tabular}

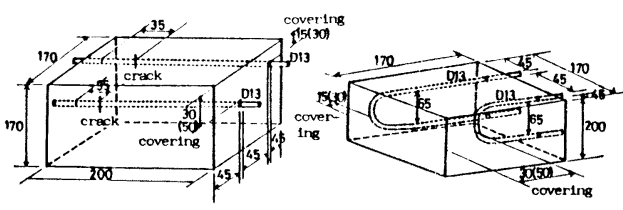

(a) Straight bar test piece (with and without pinhole)

(b) Bend bar test piece (with crack)

Fig. 1 Shape and size of concrete block test piece

Table 2 Maximum adhesion strength of epoxy coated and non-coated steel bar to concrete

\begin{tabular}{|c|c|c|c|c|}
\hline achesion strength : $\mathrm{kg} / \mathrm{cm}^{2}$, coating thickness \\
\hline $\begin{array}{c}\text { knot } \\
\text { epoxy } \\
\text { coated }\end{array}$ & $\begin{array}{c}\text { 1ateral } \\
\text { type }\end{array}$ & $\begin{array}{c}\text { cross } \\
\text { type }\end{array}$ & $\begin{array}{c}\text { screw } \\
\text { type }\end{array}$ & $\begin{array}{c}\text { rourd } \\
\text { bar }\end{array}$ \\
\hline $\begin{array}{c}\text { ncor } \\
\text { coated }\end{array}$ & 114.0 & 91.3 & 104.5 & 31.7 \\
\hline $\begin{array}{c}\text { coated } / \\
\text { non-coated }\end{array}$ & 0.82 & 0.87 & 0.93 & 0.58 \\
\hline
\end{tabular}

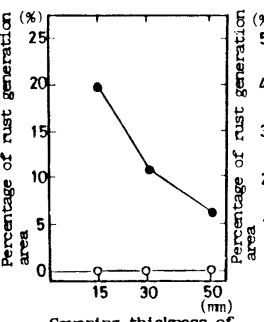
Covering thickness of (a) After on-shore test

Fig. 2 Percentage of rust generation area on steel bar after exposure test

エポキシ塗装鉄筋はコンクリートとの付着性も良く、治岸大気および飛沫带で優れた耐食性を示した。 


\title{
(453) 板合わせ材の腐食に及ぼす間陌、食塩水濃度、浸漬時間の影響
}

\author{
川崎製鉄 技術研究所工博 木村 肇 ○紐田 博
}

海野茂理博 市田敏郎

\section{1. 目的}

車体内部の腐食は食塩水などの腐食液の侵入と滞留が生じやすい，微小な間隙をもつ板合わせ部にお いて最も顕著であり，塩害地走行車などから実証されている。とのような板合わせ部の腐食举動に関し， その構造と䁉食環境因子として，(1)間隙，(2)食塩水濃度，(3)浸漬時間の影響を調べた。

\section{2 実験方法}

(1)供試材：冷延鋼板（CR），電気 Znめつき鋼板（ $\mathrm{E} \mathrm{G}$, $\left.20 \mathrm{~g} / \mathrm{m}^{2}\right)$ を溶剤脱脂後, C R と E G を組合わせて用いた。

(2)板合わせ試験材の構造（Fig. 1)：C R と E Gの間に塩 ビシートをはさみ，所定の間隙 $(0.2,0.5,1.0 \mathrm{~mm})$ 上炭食 面積（たて $100 \times よ こ 70 \mathrm{~mm}$ ）をもつ板合わせ材を作製した。 下端に梁さ $5 m m$ の液溜め在設け，外面はシールした。

(3)腐食環境条件：各種濃度の $\mathrm{NaCl}(1,3,5 \mathrm{wt} \%)$ に 所定時間浸漬後 $(0.25,1,3,6 \mathrm{hr})$ ),鉛直に保持, 乾燥し た。実験は室温で行い，1 cycle/dayとした(週末は乾燥)。

\section{3. 実験結果と考察}

(1)間隙の影響（Fig. 2）：間隙が広くなるに従って C R の腐食は増大したが, E Gは 0.5 m で最大腐食减量を示し た。 $0.2 \mathrm{~mm}$ では錆が間隙に早期に詰り，酸素供給不足とな り，腐食速度が低下した。1 mmでは錆が間隙全体に詰らず, E G 表面に生成する水酸化亜鉛主体の保護首により，腐食 が抑制されていた。板合わせ材の試験では，腐食の促進性 を考虑すると，間隙は $0.5 \mathrm{~mm}$ が適切と考えられる。

(2) $\mathrm{NaCl}$ 濃度の影響（Fig. 3)：腐食減量は $3 \% ， 5 \%$ $\mathrm{NaCl}$ に比べて, $1 \%$ の方がやや多い結果を得た。Table 1 亿融雪塩を含屯水成分の一例を示す。道路で採取した水 には $\mathrm{NaCl}$ が $0.71 \%$ 含まれ，車に付着した水は $1.08 \%$ であった。 これから実車は厳しい崕食環境下にある上みられる。

(3)浸漬時間の影響（Fig. 4）：0.25, $1 \mathrm{hr} の$ 場合, 腐食減 量は少ないが, 最大炭食深さが大きく, 錆内・外部の酸素 濃焱電池形成が支配的に生じ, 局部腐食が進行している。 $3,6 \mathrm{hr}$ の場合, 最大窝食深さが比較的小さく，ガルバニッ ク腐食が主に進行し，均一腐食に近づくと考元られる。

\section{4. まとめ}

(1)板合わせ材の腐食は間隙の影響が最も大きい。

(2)鋼板の耐穴あき性を評価する試験条件は間隙 $0.5 \mathrm{~mm}$,

$\mathrm{NaCl}$ 濃度 $1 \mathrm{wt} \%$, 浸漬時間 $1 \mathrm{hr}$ が適当と考光られる。
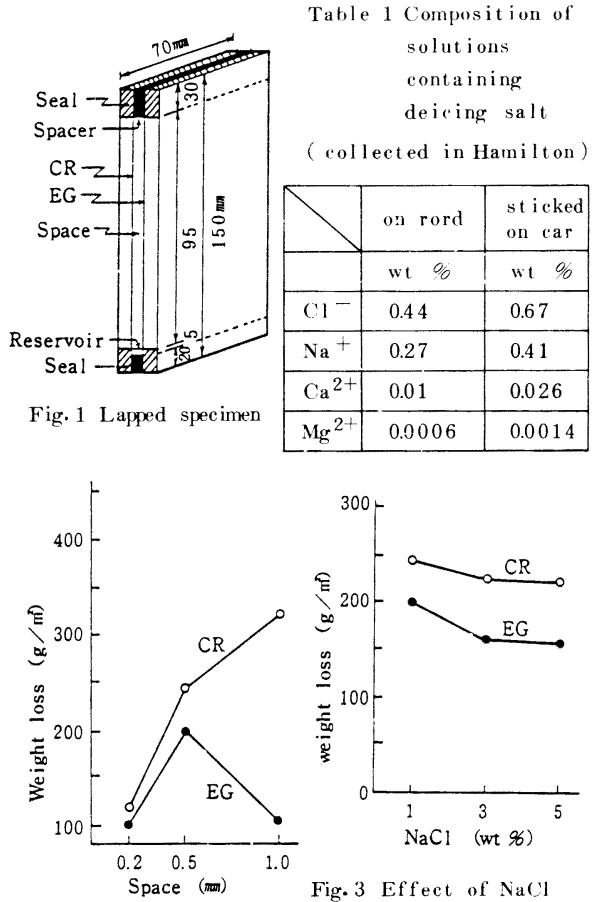

Fig. 2 Effect of space on corrosion

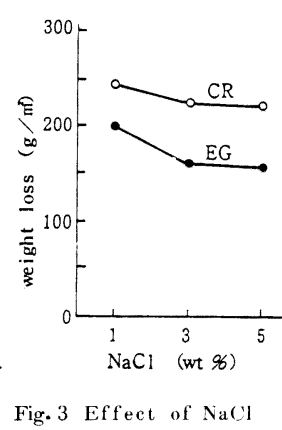
concentration on corrosion

$(1 \% \mathrm{NaCl}, 1 \mathrm{hr}) 20$ cycles $(0.5 \mathrm{~mm}, 1 \mathrm{hr}) 20$ cycles

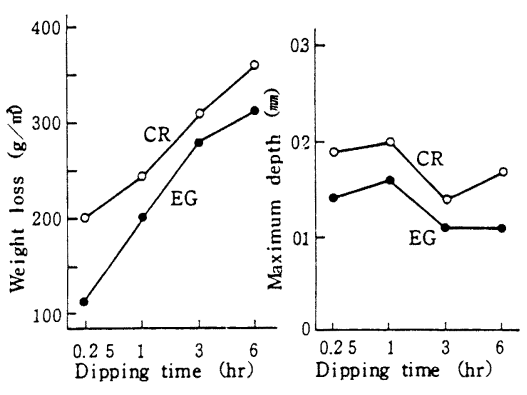

Fig. 4 Effect of dipping time on corrosion $(1 \% \mathrm{NaCl}, 0.5 \mathrm{~mm}) 20$ eycles 


\section{（454）冷延銅板の塗装後耐食性におよぼす化成処理の効果}

' $84-\mathrm{S} 455$

日本鋼管(侏技術研究所

\section{1. 緒 言}

塗装鋼板の耐食性は，塗装下地の化成処理の有無により大きく変化する。本報では，冷延鎆板の塗装 後涌食性におよぼす化成処理の効果を明らかにするために，インピーダンスの周波数応答性などの電気 化学的測定を行ったので報告する。

\section{2. 実験方法}

試験に用いた冷延鋼板は，塗装に先立って電解脱脂を行ったのち，化成処理(パーカーライジング・ B T - $\left.30 \begin{array}{lll}0 & 0\end{array}\right)$ を施した。塗料には，クリヤーエポキシ樹脂を用いた。その膜厚は $20 \mu m$ である。

分極特性; $0.02 \mathrm{MNa}_{2} \mathrm{CO}_{3}-0.1 \mathrm{M} \mathrm{NaCl}$ 水溶液中において, 無塗装鋼板の分極曲線を電位走查 法により求めた。インピーダンス測定 ; 交流印加電圧 $30 \mathrm{mV}$, 三電極法によって測定した。

\section{3. 結 果}

図 1 は，塗装鋼板と無塗装鋼板との間に流れるガルバニック電流の経時変化である。化成処理を施す と,ガルバニック電流は，無処理のものに比較して約 $1 / 100$ 程度に减少する。このガルバニック対 では, 塗装鋼板がカソードとなる。そのため塗膜下の溶液はアルカリ性を示す。アルカリ環境中では, 図 2 に示すように，化成処理を施すとカソード電流密度は减少する傾向にある。図 3 は，塩水噴霧にさら した塗装鋼板のインピーダンスの周波数応答性を示したものである。化成処理を施していない塗装鋼板 のインピーダンスの低周波数側での応答は，初期には，例えば活性態一不動態の遷移域にみられる-180 の位相差のインピーダンスを示し, 時間の経過とともに-900に変化する。他方，化成処理を施すと， 暴露初期から-900の位相差を示し, かつ塗膜下腐食に関与する低周波数域のインピーダンスは増大 する。

\section{4. 結 論}

冷延鋼板に化成処理を施すと, 塗膜下における腐食反応の面積が減少し，かつ腐食のカソード反応抵 抗が増大する。したがって塗膜下の腐食反応は抑制される。

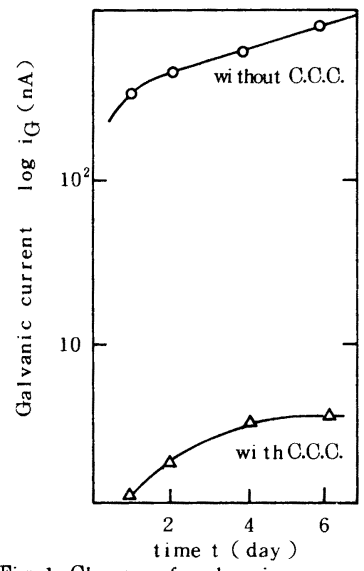

Fig. 1 Change of galvanic current with immersed time in 5 wt\% $\mathrm{NaCl}$ solution.

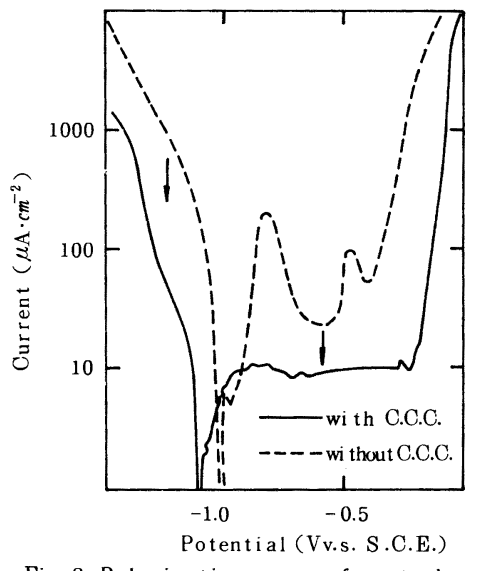

Fig.2 Polarization curves for steels with and without chemical conversion coatings (C.C.C) in carbonate buffer solution.

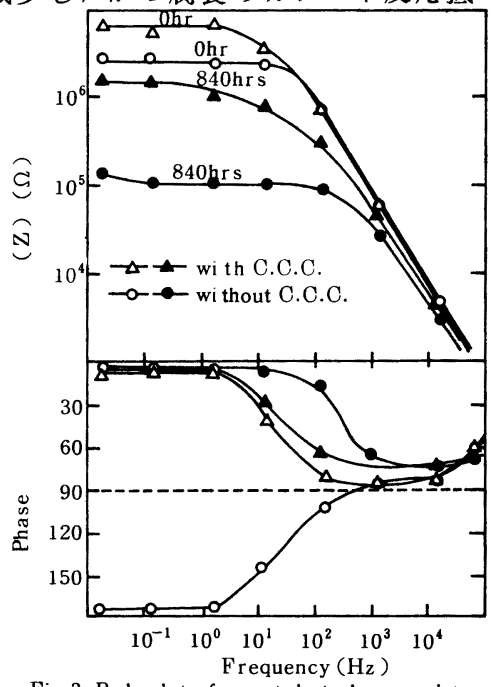

Fig.3 Bode-plots for coated steels exposed to salt spray tester. (Impedance responce was measured in $5 \mathrm{wt} \% \mathrm{NaCl}$ solution.) 
(455)カソード分極举動から业鉛合金めっきの而悢性評洒の検討

\section{1、緒言}

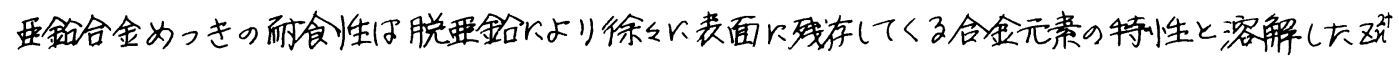

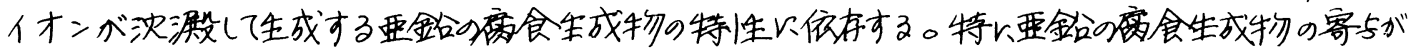

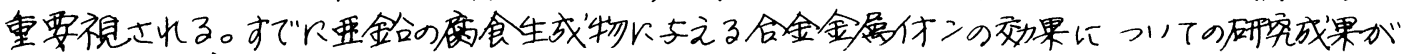

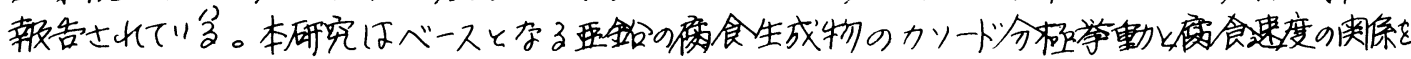

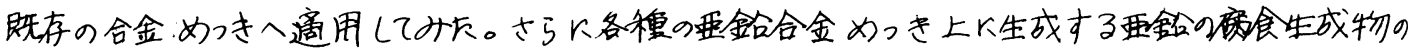

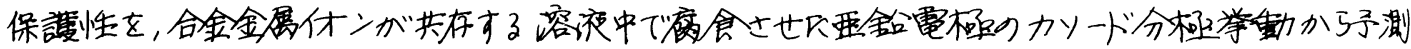
する手法を試甫る。

\section{2・实梌方法あよび結果}

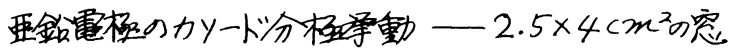

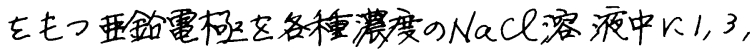

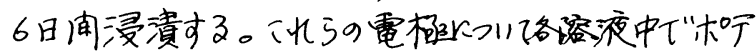

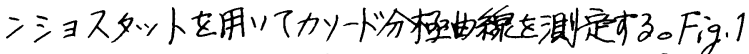
КIN NaCe中での分極曲線を示才。自然電位近停の-1.0

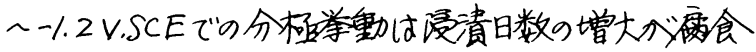
速度を增加するてとを示して1る。ー1,3〜-1,5V.SCEの籍囲 ではー1.4V、SCEを境にニフ9ピークが現われる。一1.4V.SCE

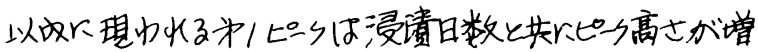
大する。可劫与腐食速度が增大すると为/ピー乌の高划 增大するてとが指椖できる。

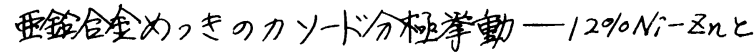

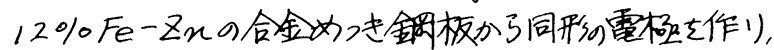

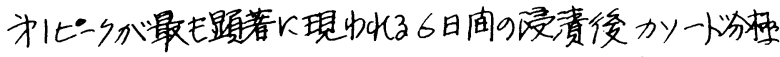

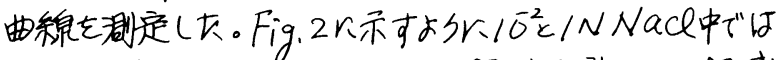

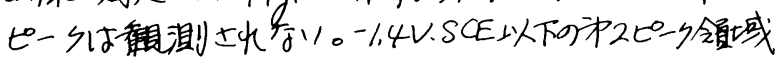

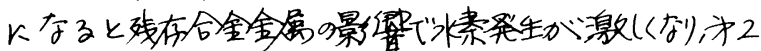

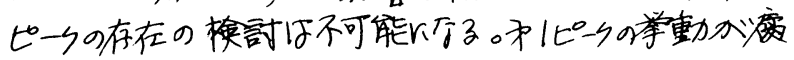

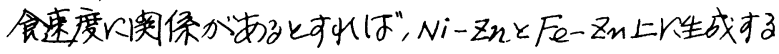

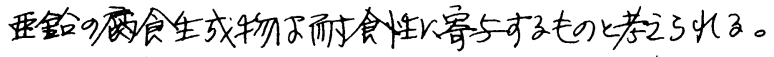

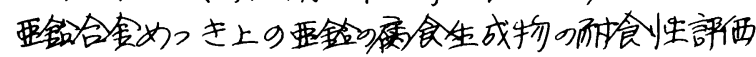

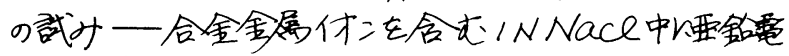

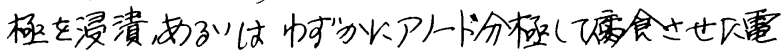
極のカリード分極曲線から事はピータの学動をかる。 Fig.3RNi ${ }^{2+}$ イオンを含む1NNaCl中て'腐食士せたl

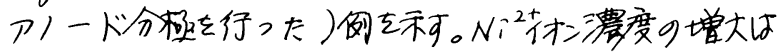
为にピータの高さを減少士せる。

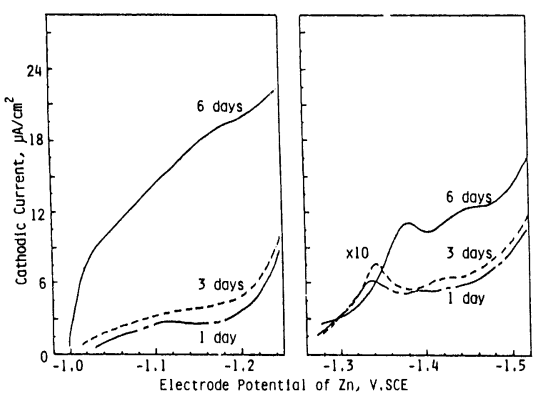

Fig. 1 Cathodic polorization curves of $z$ InC in IN NaCl.

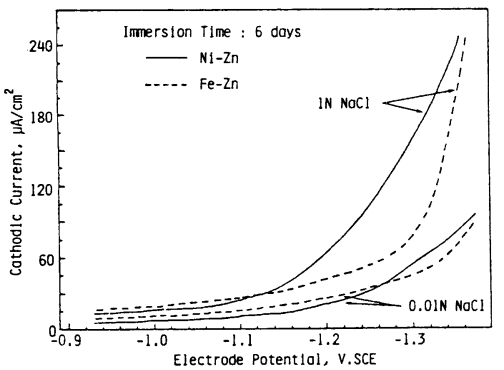

Fig. 2 Cothodic polorization curves of N1-Zn olloy and $\mathrm{Fe}-\mathrm{Zn}$ olloy cooted steel in iN and $0.01 \mathrm{~N} \mathrm{NoCl.}$

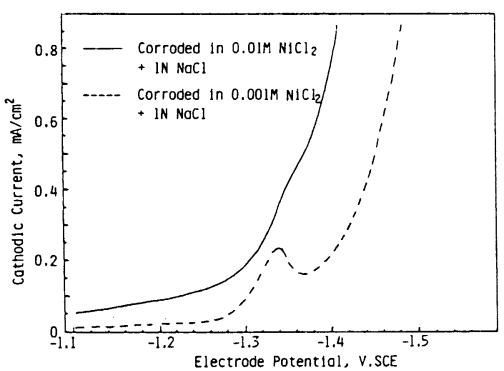

Fig. 3 Cothodic polarizotion of zinc, polorized onodically in solutions contalning $\mathrm{Ni}^{2+}$, in NaCl.

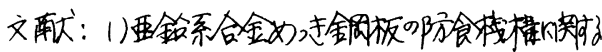

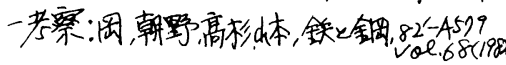


' $84-\mathrm{S} 457$

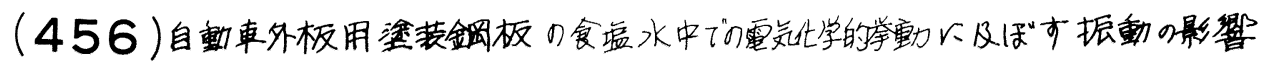

東京大学 工学部

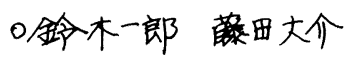

\section{1. 緒言}

走行中の自動事の外板は200 Hz以下の音波領域の振動を受ける。の程度の振動が实绦い

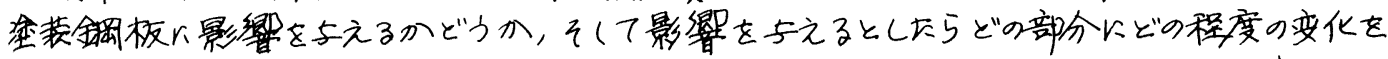

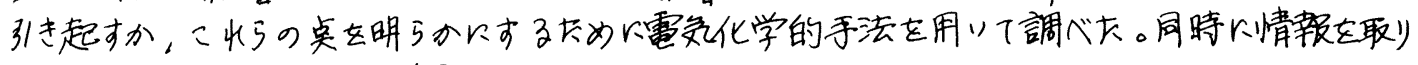
出す各種の方法以つリても検討した。

2. 实略方法抽結果

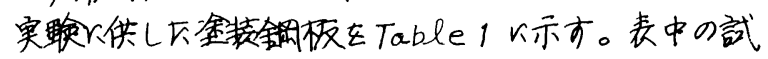
料Aを用いTFig.1 个示した二対のガルバニック対をも

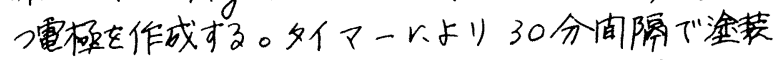

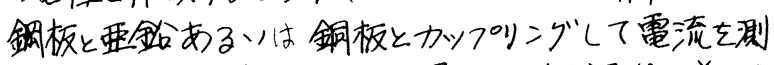
定する。館和食壏水中での各電槡の自然電位の差は $E_{c u}-E_{\text {steel }} \doteqdot 400 \mathrm{mV}$, Esteal $-E_{z x} \doteqdot 400 \mathrm{mV}$ て"

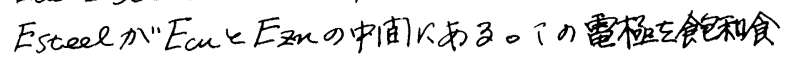
熄水中以浸清して一日2時间，100あるいは200 Hzの振動を

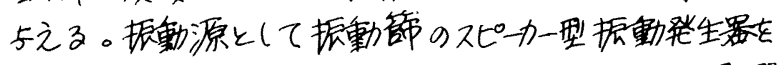
用いた。Fig.2Кガルバニック電流以与える振動影丝

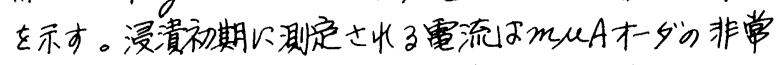
以小さい電流值である。20日浸清後，電流值が6 m $\mu$ A 以下の超常值以逢したとて3で100 Hzx2hrs/dayo 振動を与えると電流が上㫒を南始する。39日目か 万振動数を200Hzx2hrs/day ト上げると電流は

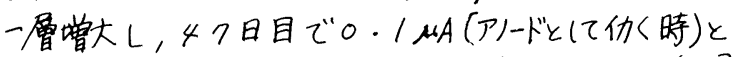

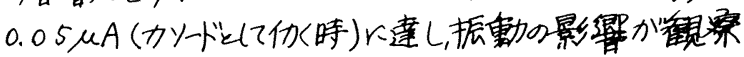

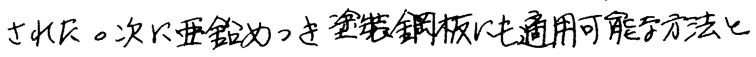
して，A，Bの武料から $2 \times / \mathrm{cm}^{2}$ の電極を作成し，ポテン

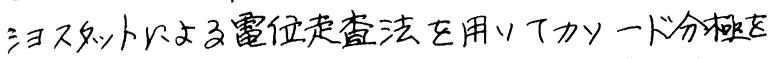

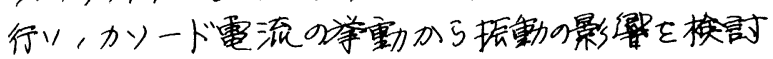

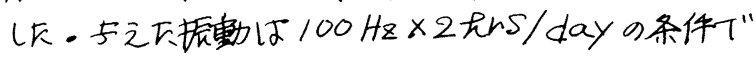
ある。坛動の影猎之調べるめ, 比較試料とにて一

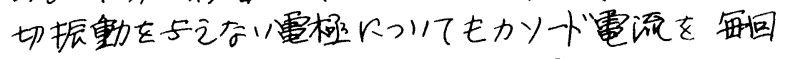

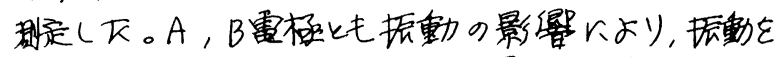
らえていない電極々比べ，大き字電流が篗測され る。A電極のー300mレ分極時の電流以対( て, B電極は-500mレの大宁る分極々もかか中うず,澌 定士れる電流は1/10 火小さり。
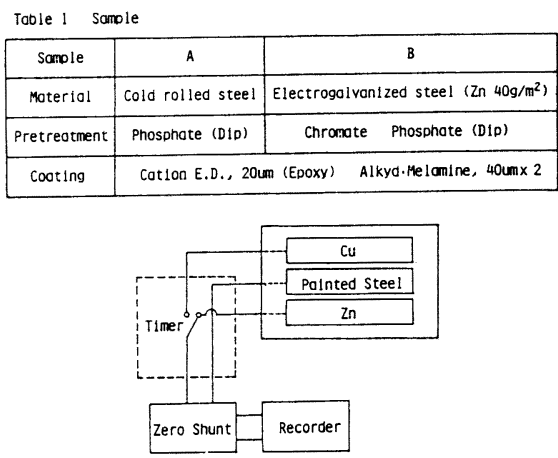

Fig. I Schematic dlogram of measurement of golvonic current.

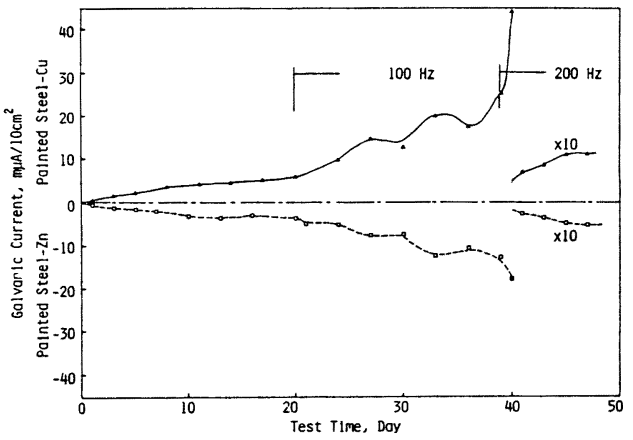

Fig. 2 Effect of vibration on galvanic current of painted steel and zinc or copper.

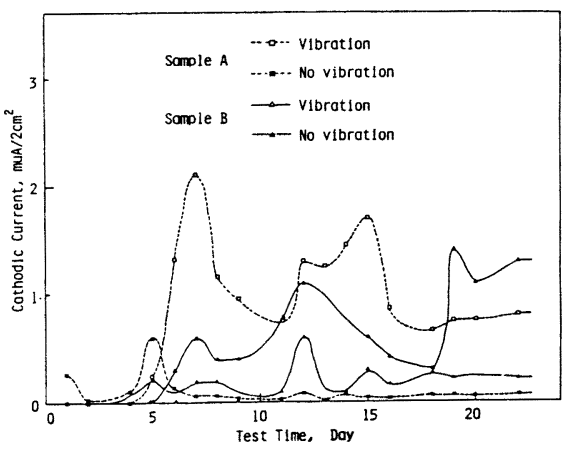

FIg. 3 Effect of vibration on cathodic current of painted steel. 


\section{1. 緒 言}

Davisk，EＳＣＡによりリン酸塩皮膜の分析を行ない，これと 耐食性との関連を議論している。 間がかかる久点がある。G D S (グリムグロ一放電分光法) は, 滐 さ方向の元素分析を短時間にでき，リン酸塩皮膜の分析壬可能であ る。 今回は，GD S より調べた各種表面処理鋼板上に形成したり ン酸塩皮膜の特性を示す。

\section{2. 実 験}

表 1 に実験に用いた各種表面処理 鋼板を示す。リン酸塩処理は, B t 3030 (日本パーカライジング社) を用いた。皮膜の組成はGD S 上よ る深さ方向の分析扎よで化学分析に

Table 1 Tested sheets.
\begin{tabular}{|c|r|}
\hline $\mathrm{SP}$ & Cold-rolled sheets \\
\hline $\mathrm{Zn}-\mathrm{Fe}$ & $\mathrm{Zn}-\mathrm{Fe}$ electroplated sheets \\
\hline $\mathrm{AS}$ & Galvannealed sheets \\
\hline $\mathrm{Gl}$ & Galvanized sheets \\
\hline $\mathrm{EG}$ & Electrogalvanized sheets \\
\hline $\mathrm{Zn}-\mathrm{Ni}$ & $\mathrm{Zn}-\mathrm{Ni}$ electroplated sheets \\
\hline
\end{tabular}
より求めた。 $\mathrm{P} / \mathrm{P}+\mathrm{H}$ は $\mathrm{X}$ 線回析より求めた。

\section{3. 実験結果と考察}

図 1 は G D S より求めた S P と G I 上のリン酸塩皮膜の滐さ方 向の組成の変化を示す。リン酸塩皮膜中に含まれる元素がすべて感 度よく検出できる。図 2 , 図 3 は G D S より得られた Pと $\mathrm{Ni}$ の積分強度と皮膜重量, 化学分析値との関係をとれぞれ示す。双 方ともに比例関係が成り立つ。リン酸填皮涘の分析上り明らかと なったことは，(1) N i は皮膜中に均一に取り込まれ，その量は1 〜 5 \%である。(2) Niの取り込まれる量はPhosphophyllite( P) よ り Hopeite (H)の方が多い。(3) G D S でのスパッ夕速度はHがP より大きい。（表 2 ) (4)水素はHでは表面で高く，Pでは皮膜中 に均一に分布している。これはHでは, スパッ夕リングで脱水 和しやすいためと思われるが, 結晶水の存在状態が違っているこ とも考えられる。(5) G D S での酸素とリンの強度比はHと Pにより異 なる。（表 2 ）X線回析の結果からはこのような組成の違いが見られ ないため, 発光収率の違いだと思われる。

このように, GDSによるリン Table 2 sputtering rate and O/P ratio in GDS. 酸程皮膜の定量分析にはスパッ夕 速度や発光収率などの補正が必要 となる。

1) J. W. D avis, SAE 820336 (1982)

2) R. Berneror, J. C. Charbonnier

Proc. $7 \mathrm{th} \mathrm{ICVM,} \mathrm{592(1982)} \mathrm{Tokyo}$

\begin{tabular}{|c|c|c|c|}
\hline & $P / P+H$ & $\begin{array}{c}\text { Sputtering } \\
\text { rate(nın/sec) }\end{array}$ & $\begin{array}{c}\text { GDS O/P } \\
\text { ratio }\end{array}$ \\
\hline $\mathrm{SP}$ & 98 & 43 & 82 \\
\hline $\mathrm{Zn}-\mathrm{Fe}$ & 94 & 46 & 75 \\
\hline $\mathrm{AS}$ & 5 & 68 & 39 \\
\hline $\mathrm{GI}$ & 0 & 73 & 44 \\
\hline $\mathrm{EG}$ & 0 & 70 & 48 \\
\hline $\mathrm{Zn}-\mathrm{Ni}$ & 0 & 75 & 45 \\
\hline
\end{tabular}

鈴木 竪市

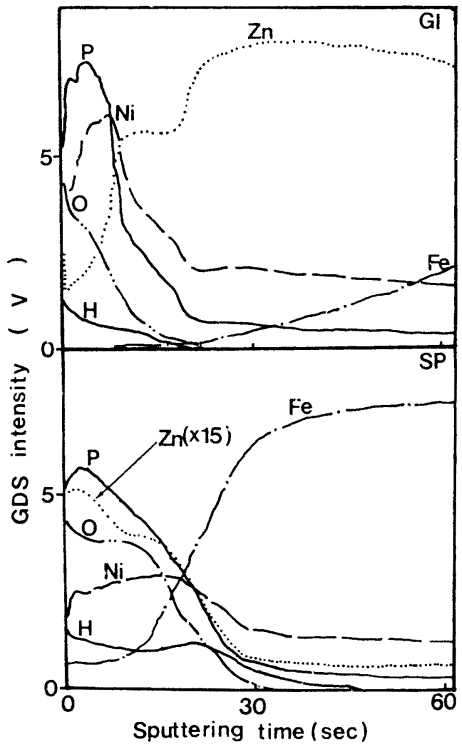

Fig. 1 Depth profiles by GDS ( $S P \& G I$ ).

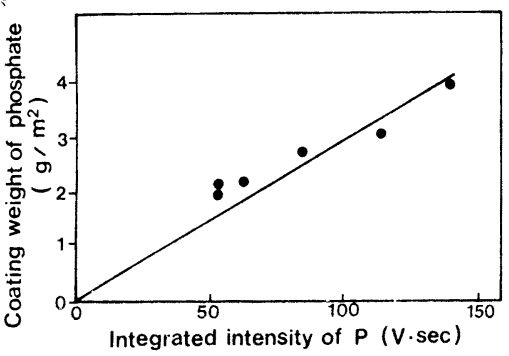

Fig. 2 Relation between integrated intensity of $p$ and coating weight of phosphate.

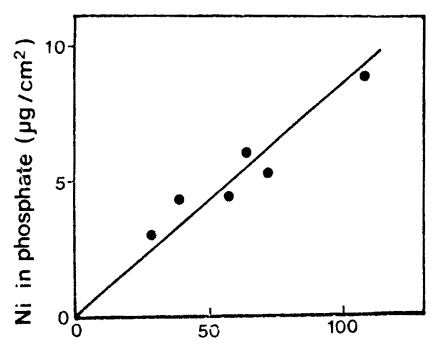

Integrated intensity of $\mathrm{Ni}(\mathrm{V} \cdot \mathrm{sec})$

Fig. 3 Reiation between integrated intensity of $\mathrm{Ni}$ and $\mathrm{Ni}$ in phosphate. 
(458) 連続焼鈍した冷延鋼板の表面特性に及ぼすボロンの影響

新日本製鐵(株) 第一技術研究所。前田重義 浅并恒敏
八幡技術研究部早川浩古野嘉邦

\section{1. 緒 言}

ボロン (B) は，強力絰化物形成元素として知られ，粒界偏析により鋼の焼入れ性を向上させるとと， BN 在形成して粒成長在阻害するAINの析出を抑制し鋼を軟質化するてと し，Bの表面特性に及侣す影響についててはこれまで報告がない。本報告では連続焼鈍によって製造され そ泠延鋼板の表面特性に及哚すＢの効果について得ら机知見老報告する。

\section{2. 実験方法}

(1) 供試材: 極低炭素 $\mathrm{Al}$ キルド鋼 $(0.002 \mathrm{C}-0.12 \mathrm{Mn}-0.05 \mathrm{Al}-0.002 \mathrm{~N})$ 亚び飞極低炭素 $\mathrm{T}_{\mathrm{i}}$ 添加鋼 ( $0.002 \mathrm{C}-0.15 \mathrm{Mn}-0.03 \mathrm{Al}-0.002 \mathrm{~N}-0.043 \mathrm{Ti})$ VB 量を変化させ , 低温巻取しを冷延板を用いて 速続焼鈍 $\left(775^{\circ} \mathrm{C}, 1\right.$ 分間保定, $400^{\circ} \mathrm{C}, 3$ 分間保定) 後, 調質压延 ( 1 \% 圧下率) した。

(2) 表面組成：オージェ電子分光並びにＩＭAで測定した。

(3) 酸化膜安定性：硼酸ソ一ダ/塩酸（pH 6.4）の緩衝溶液を用い, 酸化膜の自動還元時間を測定した。

(4) 表面反応性：リン酸塩処理の際の析出核となるチタンコロイド 及じニッケル核の吸着を前報に示す方法で測定した ${ }^{2)}$ 。

\section{3. 実験結果}

(1) B は焼鈍によって表面にバルクの 2 亿 千倍涶化する。濃化は フリー Bのある $\mathrm{Ti}$ 添加鋼で大である。(2) 表面 Bは BNとして存在 している。 $\mathrm{N}$ 源としては, ガス成分及び鋼中 $(\mathrm{BN} \rightleftarrows \mathrm{B}+\mathrm{N})$ からの 両方が考えられる。(3) B は M n, P, Cr, T i などの表面濃化在抑制するが，C注增える。 (4) Bの表面濃化により, 酸化膛の目動摙元 が起り易くなり、ニッケル核の败着が增える。 但しチタンコロイドの吸着は極大值を示す。 (5) リン酸塩処理性は B 添加により改善さ れるが，高すざると低下する傾向を示した。 4. まとめ

B 添加鋼の表面には、 BNが著しく濃化し， 他の成分の表面
濃化が抑制され
かつ表面が活性
化される。
文 献
(1) 高橋他: 鉄と
鎆, $83-\mathrm{A} 301$
(2) 前田他: 鉄と
龬, $83-\mathrm{S} 456$

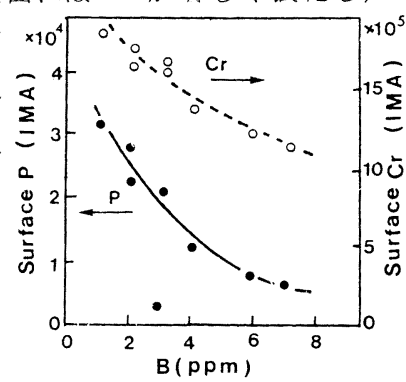

Fig. 4 Surface enrichment of $\mathrm{P}$ and $\mathrm{Cr}$

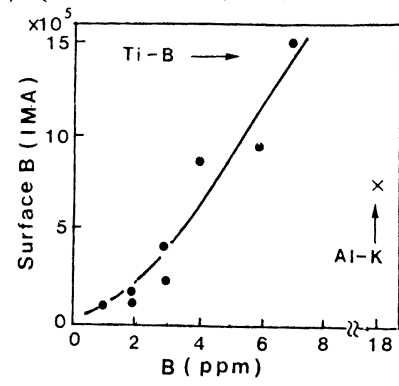

Fig. 2 Surface enrichnent of $B$

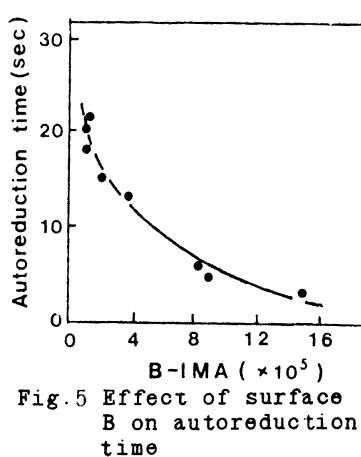

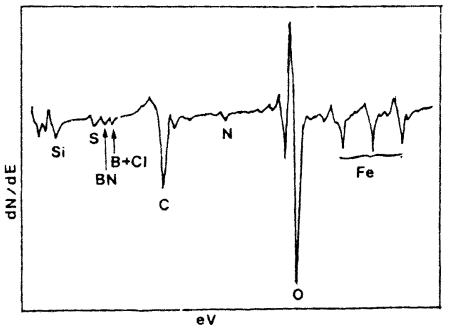

Fig. 1 AES spectrum of Ti-B steol (Continuous annealing)

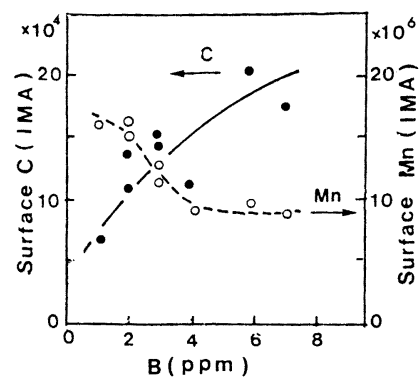

Fig. 3 Surface enrichment

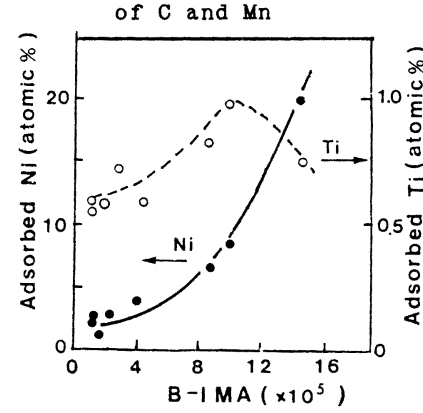

Fig. 6 Effect of surface $B$ on nucleation of $\mathrm{Ni}$ and $\mathrm{T} i$ 
(459) 冷延鋼板の耐スキャブコロージョン性能の向上 ( 冷延鋼板の表面性状の研究一第 1 報一)

新日本製鐵(侏)名古屋技術研究部

森田順一 ○糟谷晃弘 加藤炤年

\section{1. 緒 言}

自動車の外板錆抑制は，車体寿命延長のニーズに応える有効な対策の 1 つであり，冷延鋼板自体の， 塗装後の耐食性向上が強く要求されている。我々は, 塗装後の冷延鋼板の塗膜損傷部から成長する系状 錆の抑制に果すリン酸塩皮膜性状の効果を検討した。

\section{2. 実験方法}

$0.8 \mathrm{~mm}$ 厚の冷延鋼板支, 市販の浸漬型りン酸塩処理液で処理し, カチオン電着塗装, 中塗り, 上塗り 塗装し, 供試材とした。耐スキャブコロージョン性能は, チッピング後の供試材を, 塩水噴霧, 湿潤雰 囲気, 屋内放置を順次繰り返す腐食促進環境サイクル下に置き, 生じた糸状錆を観察することにより評 価した。

\section{3. 結 果}

スキャブコロージョンテストで生じた錆の実体顕微鏡像を photo. 1 に示した。任意の方向に糸状の錆の進行が観察される。この糸状錆部 の塗膜を剝離し，E P M A により観察した結果をFig.1のモデル図に 示した。糸錆の周辺部(1)では, リン酸塩結晶が存在するが, 進行方向 の突端部(2)では， Zn，Pが検出されずリン酸塩結晶が存在しない。ま た, (3)の部分では, $\mathrm{Fe}, \mathrm{C} \ell か ゙$ 検出され, $\mathrm{FeCl} 2$ として存在し, $\mathrm{pH}$

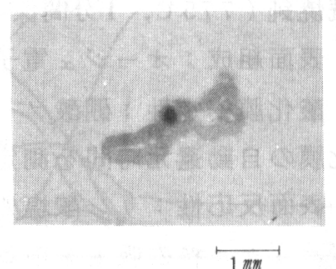

Photo. 1 Scab corrosion by stereomicroscope 低くなっているととが推察される。また，(4)の部分では， $\mathrm{Zn}, \mathrm{P}$ は検出されるが,リン酸塩結晶は認められず突端 部(2)で溶解したリン酸塩結晶の $\mathrm{Zn}, \mathrm{P}$ が水酸化物等とな り錆中に含まれているととが考えられる。以上より, 従 来, 塗装したローモ板等で生じていた糸錆 ${ }^{12)}$ と塗膜厚が $100 \mu$ 程度と厚いこと, リン酸塩皮膜が存在する点で異な るが, 糸錆の成長の本質的なメカニズムは変わらず, 系 錆の進行は, アノード反応 $\left(\mathrm{Fe} \rightarrow \mathrm{Fe}^{2+}+2 \mathrm{e}\right)$ とカソー

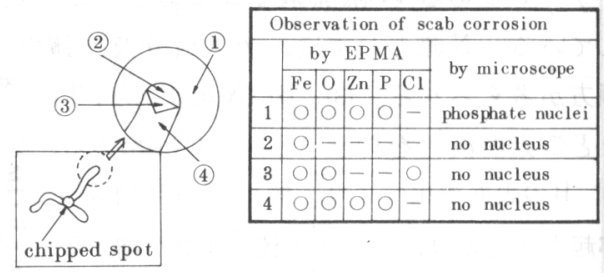

Fig. 1 Scab corrosion model ド反応 $\left(1 / 2 \mathrm{O}_{2}+\mathrm{H}_{2} \mathrm{O}+2 \mathrm{e} \rightarrow 2 \mathrm{OH}^{-}\right)$のカップリング反応で, 塗膜下を水平方向に進行していると考え られる。カソード部で $\mathrm{pH}$ が上昇し,リン酸塩結晶を溶解しながら系錆が進行している（突端部 (2)) とと より, スキャブコロージョン抑制には, リン酸塩皮膜の効果が大きく, Fig.2 に示したように, リン酸 塩皮膜量, $\mathrm{P} / \mathrm{P}+\mathrm{H}$ 比が大き くなる程，良好となる。

\section{〈参考文献〉}

1）前田：金属表面技術 29,

8, $388-396$ ( 1978 )

2) H. H. Uhl ig 著, 松田, 松島訳 “腐食反応とその制御” P. $241-244$
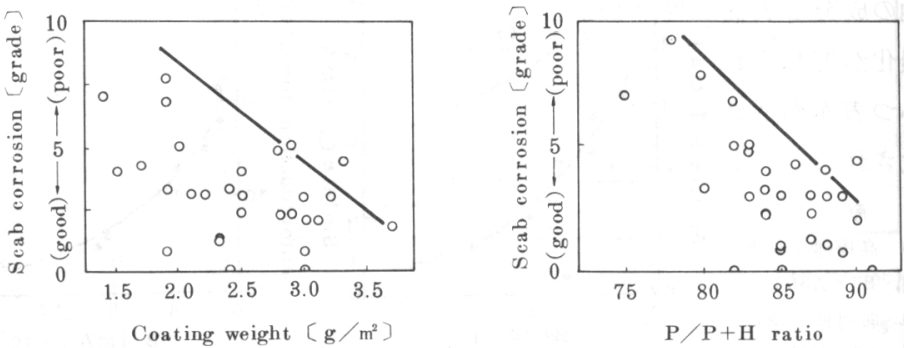

Fig. 2 Effect of phosphate film on scab corrosion 


\section{（460） Zn-N i 系合金めっき鋼板の耐水密着性}

一自動車用鋼板の塗膜密着性に関する研究（第 4 報）—

新日本製鐵(株) 広畑技術研究部 $\bigcirc$ 斎藤隆穗 小田島寿男 平野吉彦 表面処理研究センター 北山實

\section{1. 緒 言}

$\mathrm{Zn}-\mathrm{Ni}$ 系合金めっき鋼板は車体防錆鋼板として有用であるが、カチオン電着塗膜と組合せた場合に化成 処理浴および電着塗膜の焼付温度によっては3コート塗膜の耐水密着性が問題とされる場合がある。酎水 密着性低下の原因は諸説があるが、化成処理を施こさない場合には耐水密着性の低下はなく、表面に形成 された化成処理皮膜の性質が化成処理の浴側因子によって変化するためと考えられた。そこで耐水密着性 に及ぼす化成処理浴組成の影響について検討した。

\section{2. 実験方法}

$\mathrm{Zn}-\mathrm{Ni}$ 系合金めつき鋼板および電気亜鉛メッキ龬板を用意し、りん酸亜鉛系浸漬化成処理を施こした後、 カチオン電着塗装 $(20 \mu)$ 、アルキド系中塗 $(30 \mu)$ 、上塗 $(30 \mu)$ を施して蒸留水に浸漬して耐水密着試験に供 した。化成処理に際して薬品の配合を変え、浴中の $\mathrm{Zn}^{+} 、 \mathrm{Ni}^{+}$濃度を変化せしめた。

\section{3. 実験結果およひ考察}

耐水密着性に及ぼす化成処理浴中の $\mathrm{Zn}$ 、 $\mathrm{Ni}^{+}$濃度の影響は極めて顕著であり、 $\mathrm{Zn}-\mathrm{Ni}$ 合金めっき鋼板、電 気覀鉛めっき鋼板のいずれの場合も浴中の $\mathrm{Zn}^{+}$濃度が低く $\mathrm{Ni}{ }^{+}$濃度が高い程耐水密着性は良好でかつ焼付温 度の影響も少なくなる（Fig. 1)

鋼板表面に形成されたりん酸要鉛皮膜のX線回折像は化成処理浴組成が変化しても hopeiteであるが化 学分析によれば、りん酸亜鉛皮膜に含まれる $\mathrm{Ni}$ 含有率が異なり、化成処理浴中 $\mathrm{Ni}^{+}$濃度が高い程、皮膜の $\mathrm{Ni}$ 含有率は高くなり耐水密着性の向上と対 応している（Fig．2）。

$\mathrm{Zn}-\mathrm{Ni}$ 系合金めっき鋼板ではりん酸垔鉛皮 膜に含まれる Niの一部はめっき層から供給さ れると考えられ、試みに $Z \mathrm{n}-\mathrm{Ni}$ 系合金めっき 鎆板の表面 $\mathrm{Ni}$ 濃度を変えて見ると、りん酸 亜鉛皮膜の $\mathrm{Ni}$ 含有率が変化することが判っ た (Fig. 3)。

これらのことから、 $\mathrm{Zn}-\mathrm{Ni}$ 系合金めっき 鋼板のカチオン電着塗装後の耐水密着性は表 面に形成されたりん酸亜鉛皮膜の性質によって 左右される。りん酸亜鉛皮膜の性質を変える のは化成処理浴中の金属イオン濃度バランス であると考えた。めっき層に含まれる $\mathrm{Ni}$ は、 りん酸垔鉛皮膜のNi含有率を上げる方向に 働らき、耐水密着上は有利となる。りん酸要 鉛皮膜の性質の変化については次報で報告す る。

(1) 北山ら：鉄と鋼, 68 (1982), A 65

(2) 内田ら：鉄と鋼, 69 (1983), S 460

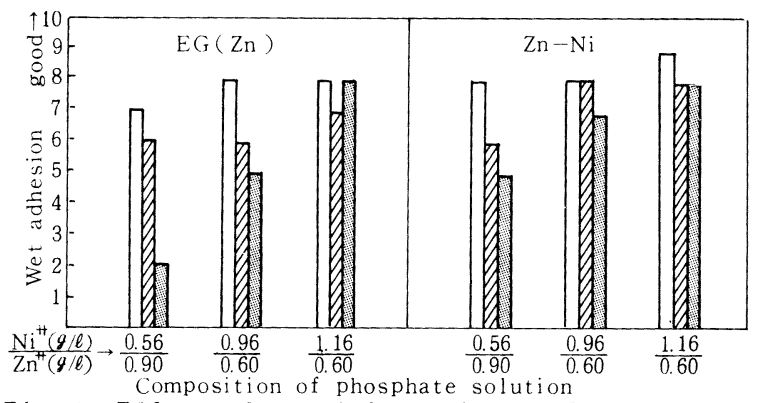

Fig. 1 Effect of metal ion balance of phosphate solution on wet adhesion.

C-ED baking temp $\square: 165^{\circ} \mathrm{C}: 175^{\circ} \mathrm{C} \square: 185^{\circ} \mathrm{C}$

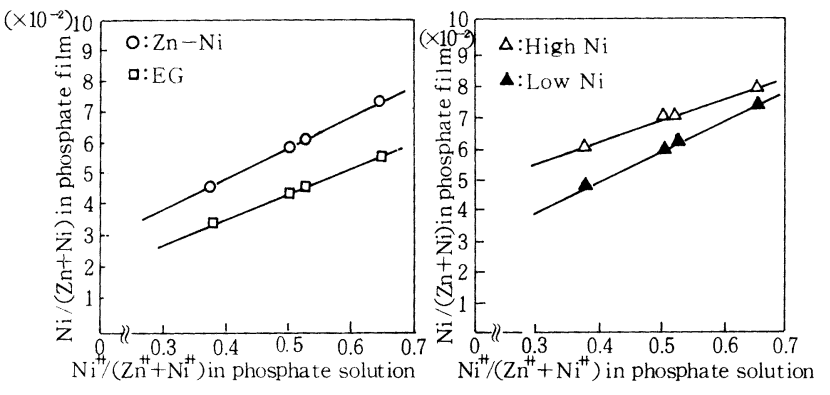

Fig. 2 Relationship between Fig. 3 Relationship between $\mathrm{Ni} /\left(\mathrm{Zn}^{+}+\mathrm{Ni}^{+}\right)$in phosphate solution and $\mathrm{Ni} /(\mathrm{Zn}+\mathrm{Ni})$ in phosphate film. $\mathrm{Ni}$ concentration of surface and $\mathrm{Ni} /(\mathrm{Zn}+\mathrm{Ni})$ in phosphate film. 


\section{りん酸亚鉛皮膜の水浸漬挙動}

一自動車用鋼板の塗膜密着性に関する研究（第 5 報）-

新日本製鐵㑣) 広畑技術研究部斎藤隆穂 ○小田島寿男 平野吉彦

表面処理研究センター 北山 實

\section{1. 緒言}

カチオン電着塗装を施した带鉛系めっき鋼板の耐水密着性は、りん酸亜鉛系化成处理浴の金属イオン 濃度の影響を受ける。化成処理浴組成に対応して形成されたりん酸亜鉛皮膜の組成変化も認められ、塗 膜焼付、水浸漬過程でのりん酸覀鉛皮膜の挙動の変化が予想されたので、この点について検討した。

\section{2. 実験方法}

表面 $\mathrm{Ni}$ 濃度の異なる 2 種類の $\mathrm{Zn}-\mathrm{Ni}$ 系合金めっき鋼板、通常の泠延鋼板および電気亜鉛めっき鋼板 を用意し、浴中 $\mathrm{Ni}^{+} / \mathrm{Zn}^{+}$濃度比を変えてりん酸要鉛系浸漬化成処理を施して試片とした。試片はそのま ま、あるいはカチオン電着塗装を $5 \mu$ 施して電着塗膜の焼付温度で熱处理し、更に蒸留水浸渍を行って熱 処理前後、水浸漬前後のりん酸亜鉛皮膜の相変化お上び形態変化を観察した。

\section{3. 実験結果および考察}

带鉛系めっき鋼板では化成処理浴中の $\mathrm{Ni}^{+}$濃度の上昇 に伴ない、また、 $\mathrm{Zn}-\mathrm{Ni}$ 系合金めっき鋼板では表面 $\mathrm{Ni}$ 濃 度の高い方が微細かつ緻密なりん酸亜鉛皮膜が形成され る。これに対応して hopeite 4 水塩の(020) および(042, $220)$ 強度が低下し、形成されたりん酸亜鉛結晶の配向性 の変化と一部非晶質化が示唆される(Fig.1)。電着塗膜の 焼付温度に相当する熱処理により hopeite 4 水塩は 2 水塩 に脱水されるが、水浸漬により 2 水塩の減少と 4 水塩の 回復が認められるが、化成処理浴中の $\mathrm{Ni}^{+}$濃度が高い程 4 水塩の回復は少なくなる。カチオン電着塗膜 $(5 \mu)$ 下

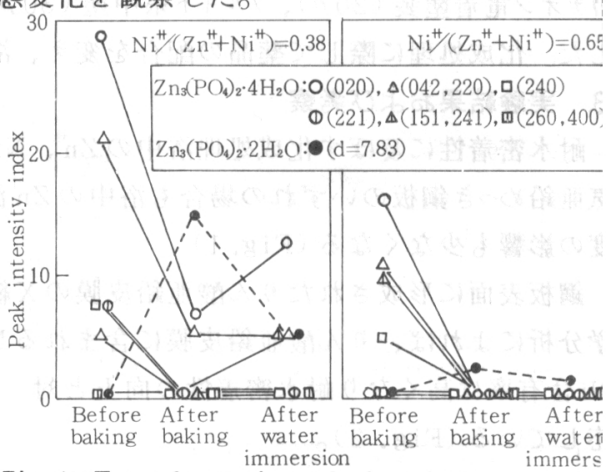

Fig. 1 Transformation of phosphates under electro-painted film of $\mathrm{Zn}$-Ni plated steel のりん酸严鉛皮膜の挙動も全く同様であり、通常の 3 コート塗装 を行った後の塗膜耐水密着性は水浸漬後の 4 水塩の回復と強い相 関が認められ、回復が少ない程耐水密着性は良好である(Fig. 2)。

冷延鋼板では phosphophyllte 4 水塩が形成されるが、焼付温度 相当の熱処理後の X 線回折像は hopeite 2 塩水と一致する。水浸 漬により 2 水塩は減少するが 4 水塩の回復は認められない。

化成処理を施したままの試片を水浸漬し、りん酸亜鉛皮膜の状 態変化を時系列的にSEM観察した。水浸漬後のりん酸亜鉛皮膜の 表面に新たな析出物の生成が認められ、 EDX 分析招よび 抽出レプリカの電子線回折からこの析出物は $\mathrm{ZnO}$ である。 $\mathrm{ZnO}$ の発生は冷延鋼板の場合にも認められ、りん酸亜鉛 皮膜の加水分解生成物と考えられる(Fig. 3 )。 帚鉛系鋼板では化成処理浴中 $\mathrm{Ni}^{+}$濃度の増に伴ない、発 生する $\mathrm{ZnO}$ の小型化、密度の減少が認められる。

以上の上うなりん酸亜鉛皮膜の挙動が耐水密着性と関 連することを考察した。

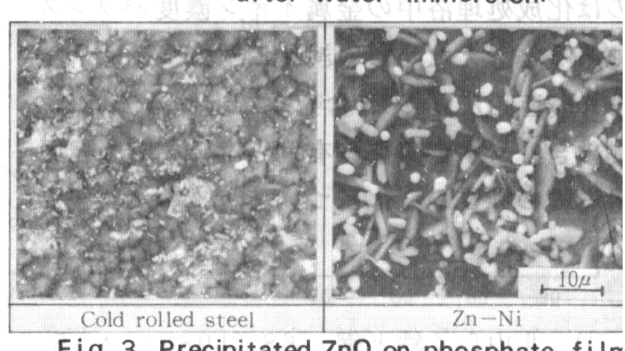

Fig. 3 Precipitated $\mathrm{ZnO}$ on phosphate filn after water immersion. 
一自動車用鋼板の塗膜密着性に関する研究（第6 報) -

$\begin{array}{lll}\text { 新日本製鐵(広烟技術研究部 } & \text { 斎藤隆穂 ○小田島寿男 平野吉彦 } \\ & \text { 表面処理研究センター 北山實 }\end{array}$

\section{1. 緒 言}

りん酸亜鉛皮膜の挙動を調査した結果、水浸漬による 4 水塩の回復現象とりん酸要鉛皮膜の表面での $\mathrm{ZnO}$ 生成が認められ、耐水密着性との関連が示された。3コート塗膜下のりん酸垔鉛皮膜が水浸漬下で かかる挙動をとるとき、体積変化を起こし塗膜の応力状態が変化すると考えられたため、この点につい て検討し、併せて塗膜下における $\mathrm{ZnO}$ の発生についての確認を行なった。

\section{2. 実験方法}

板厚 $0.3 \mathrm{~m} / \mathrm{m}$ の冷延鋼板およびそれを母材としてそれぞれ $20 \mathrm{~g} / \mathrm{m}^{2}$ の電気めっきを施した電気带鉛めっき 鋼板および $\mathrm{Zn}-\mathrm{Ni}$ 系合金めっき鋼板を用意した。試料調整は鋼板の片面のみにりん酸覀鉛系浸漬化成

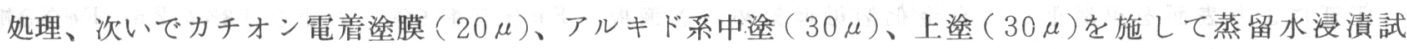
験に供した。化成処理に際して浴組成は亜鉛系めっき鋼板の塗膜耐水密着性を低下させる目的で浴中Ni 濃度を低下した浴を使用した。

焼付により塗膜は収縮するため片面塗装を施した試験片は塗膜を内側にして曲がる。この現象を梁の 曲げに近似すれば、鋼板に㗢く曲げ応力は次式で示される゙ので、曲りを測定することにより水浸漬前後

$$
\begin{aligned}
& \alpha=2 \mathrm{E} \mathrm{T}^{2} \mathrm{H} / 3(1-\nu) \mathrm{t}^{2} \\
& \mathrm{E}: \text { ヤング率, レ: ポアンン比, } \mathrm{t}: \text { 鋼板の板厚 } \\
& \mathrm{T}: \text { 塗装試片の板厚, } \mathrm{H}: \text { 板の曲り, } 1 \text { : 試片長さ }
\end{aligned}
$$

の応力変化を追跡した。

\section{3. 実験結果と考察}

電着塗装、中塗り、上塗りを施こすに従がい、また電着塗 膜の焼付温度が高い程鋼板に働く塗膜の収縮力は大きくなる。 水浸漬により塗膜は吸水し膨潤するため一端緩和されるが、 乾燥すれば再び塗膜は収縮する。乾燥により回復した曲げ応 力のレヘルは水浸漬前のレベルには回復しないが、 $\mathrm{Ni}^{+}$イオン 濃度を下げた浴で化成処理を施した亜鉛系鎆板では水浸漬前 との差が大きくなる（FiG. 1)。水浸漬による塗膜の吸水は短 時間の乾燥で脱水する゙ので、塗膜 /りん酸覀鉛皮膜 / 鋼板か らなる 3 層力学モデルで水浸漬により塗膜およびりん酸亜鉛 皮膜の体積増があり、乾燥により塗膜は収縮したがりん酸亜 鉛皮膜は収縮しなかったとして上述の挙動を説明出来る。

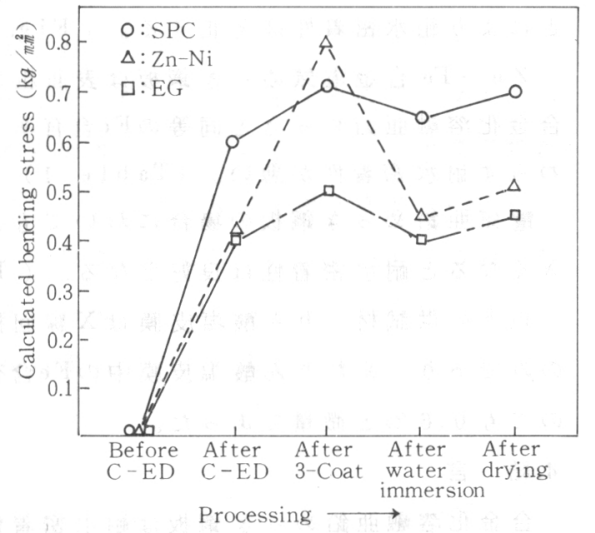

Fig. 1 Change of bending stress before and after water immersion of 3 coated sample.

水浸漬後の塗膜表面にナイフカットを入れると耐水密着性が低下し ている場合には塗膜の残留張力が解放され、収縮する現象が測定され る。セロテープ剥離後の剥離界面はEPMAのりん分析結果から見れば 塗膜/りん酸亜鉛皮膜の界面に近い。剝離面の抽出レプリカの電子線 回折で、塗膜側および鋼板側の両方の面から $\mathrm{ZnO}$ を検出した(FiG.2)。 以上の結果に基づき耐水密着性につい七考察する。

1) 野沢忠生：学位論文 (1981)

2) 伊藤ら：鉄と鋼，68(1982), S 1096
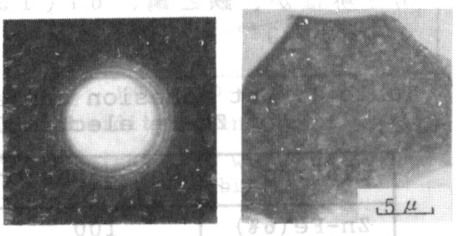

Fig. 2 Extracted $\mathrm{ZnO}$ from exfoliated paint film after water immersion. 
（463）合金化溶融要鉛めっき鋼板の耐水密着性におよぼす表面粗さの影響

侏神戸製鋼所加古川製鉄所 ○岩井正敏堺 裕彦

野村伸吾（工博）小久保一郎

1. 緒言

垔鉛めっき鋼板の耐水密着性は、冷延鋼板に比べ般的に劣っている。との原因として、りん酸塩処 理時に生成する結晶が phosphophylliteではなくhopeiteであるととが考えられる。(1)しかし合金化溶 融亜鉛めっき鋼板の場合には、hopeiteが生成するにもかかわらず耐水密着性が良好な場合が多く、必 ずしも上記の理由のみでは説明できない。本報ではての原因について表面粗さの観点から調査した結果 について報告する。

2. 実 験 方 法

圧延により表面を平滑化した合金化溶融亜鉛めっき鋼板、Fe合有率 $6 \%$ 、および $13 \%$ $\mathrm{Zn}-\mathrm{Fe}$ 合金電 気めっき鋼板、表面粗さの異なる電気亜鈶めっき鋼板（純 $\mathrm{Zn} ）$ を供試材とした。電気めっきは硫酸塩浴 にて行ない、めっき原板にはブライト圧延板を用いた。塗装は自動車用榇装工程にしたがい、浸漬法り ん酸塩処理一カチオン電着塗装一中上幄を行ない、とれ を $400^{\circ} \mathrm{C}$ 温水中に 10 日間浸漬後、 $2 m m$ ゴバン目試験 を行ないはく離個数 $/ 100$ 個にて耐水密着性を評価した。 3. 結 果

合金化溶融垔鉛めっき鎆板は圧延により平滑化すると とにより耐水密着性は劣化する。(Fig. 1)

$\mathrm{Zn}-\mathrm{Fe}$ 合金電気めっき鋼板は表面粗さが小さいため、 合金化溶融亜䠰めっきと同等のFe含有率であるにもかか わらず耐水密着性が覀い。（Table 1$)$

電気垔鉛めっき鋼板の場合においても、表面粗さが大 きくなると耐水密着性は良好となる。（Fig. 2)

以上の供試材のりん酸塩皮膜はX線回折にてはhopeite のみであり、またりん酸塩皮膜中の $\mathrm{Fe}$ 含有率も最大のも のでも $0.6 \%$ と微量であった。

\section{4. 結言}

合金化溶融覀鉛めっき鋼板は耐水密着性が良好である。 これには表面粗さの寄与が大きいととが明らかになった。 参考文献

(1) 堺はか、鉄と鋼、67(1981)S980

Table 1. Wet adhesion and surface roughness of $\mathrm{Zn}-\mathrm{Fe}$ electroplated steel sheet.

\begin{tabular}{|l|c|c|}
\hline plating & wet adhesion* & $R \max$ \\
\hline $\mathrm{Zn}-\mathrm{Fe}(68)$ & 100 & $1.6 \mu \mathrm{m}$ \\
\hline $\mathrm{Zn}-\mathrm{Fe}(138)$ & 99 & $1.7 \mu \mathrm{m}$ \\
\hline
\end{tabular}

* number of adhesion failure/100

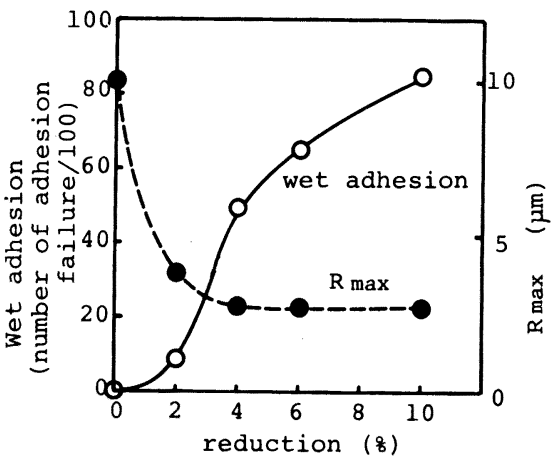

Fig.1. Effect of surface roughness on wet adhesion of galvannealed steel sheet.

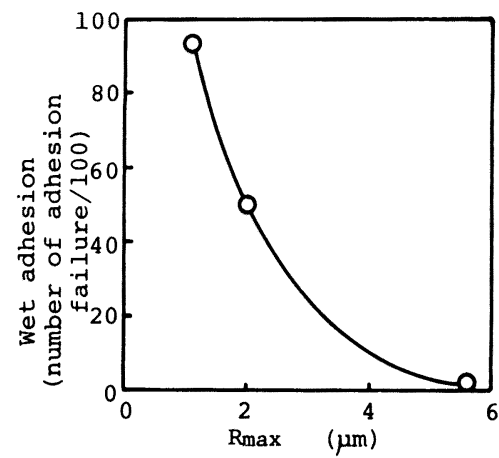

Fig.2. Effect of surface roughness on wet adhesion of $\mathrm{Zn}$ electroplated steel sheet. 
Al，Mg含有浴融垔鉛めつき銅板の黑変現象

(浴蠤要鉛めつき銅板の高湿度澴境下での表面变色一近)

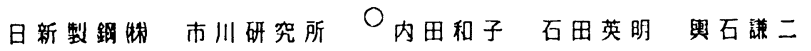
片山豆一郎出口武典公文史城

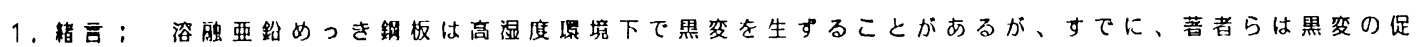

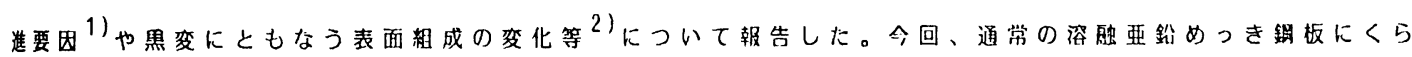

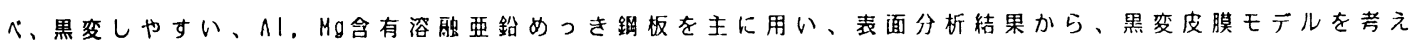

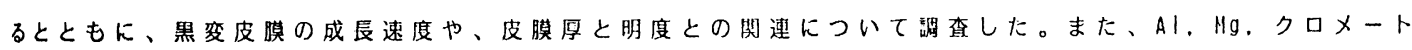
皮脱等の黒变促進作用並びに黒变皮膜の防食性について考察した。

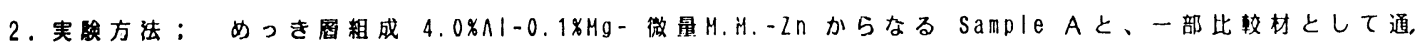

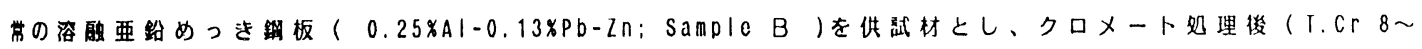

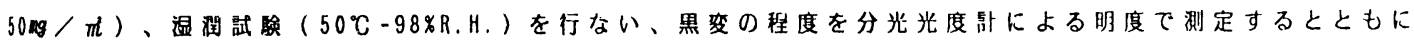
$E S C A ， A E S ， S A M$ 等の表面分析を行ない、皮骐厚などを测定した。

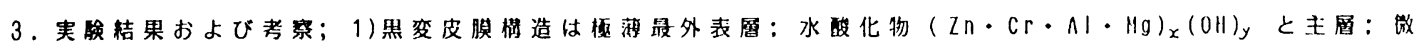
面 $\mathrm{Mg}, \mathrm{Cr}$ 合有した( $\mathrm{n} \cdot \mathrm{Al})_{x} 0_{y}$ から成ると考えられた。皮脱の下では、部分的にAlが酸化物として存在

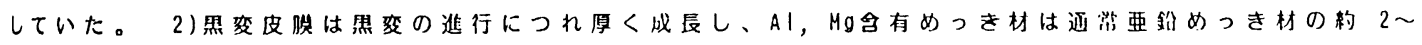
2.5 倍の速度で生成し、埋変が進行すると料1000〜 $1500 \AA$ 厚となっていた( Fig.1)。また同一皮膜厚でもA ， Ho含有めっき材の方が明度は通常严鉛めっき材にくらべ低く(Fig.2)、Al，Mgを含有すると黒変皮脱の生成が 促進されるだけではなく、寻有AI，Mg酸化物などのためより黒く見えることがわかった。3)クロメート皮

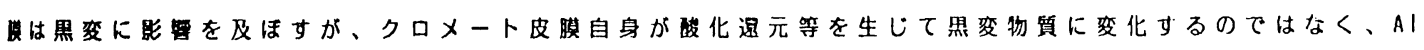

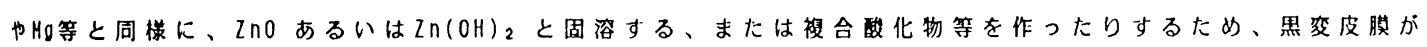

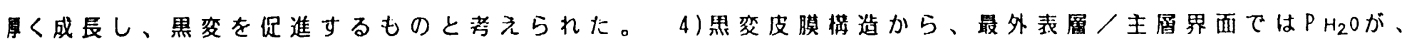

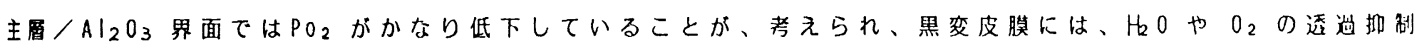

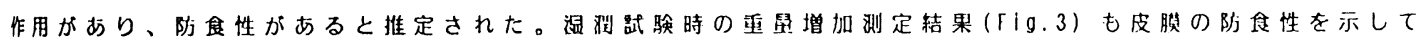

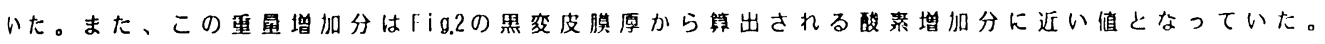

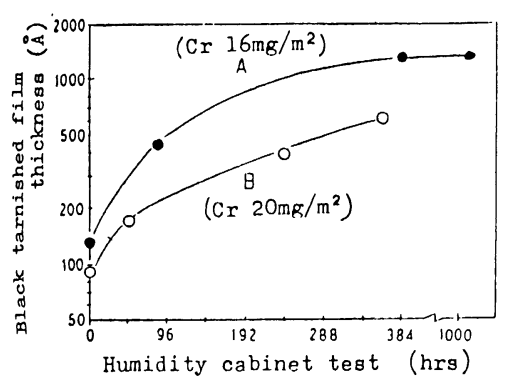

Fig. I Increase of black tarnished film thickness with humidity cabinet test

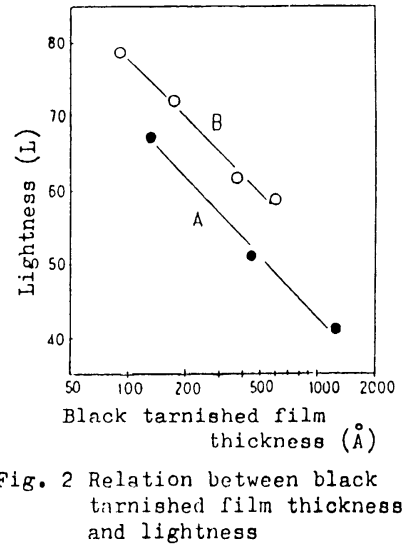

1)内田他：鉄之䤡，69(1983) S1055。

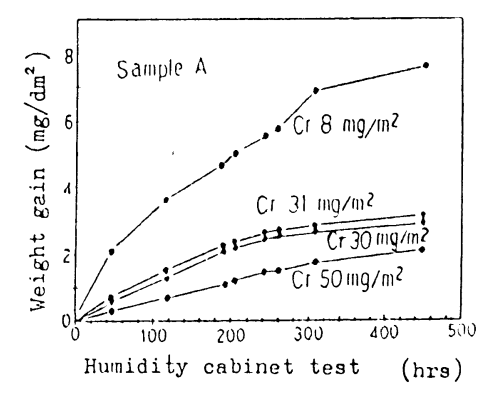

Fig. 3 weight gain with humidity

$$
\text { cabinet test }
$$


(465) 高メッキ密着性深絞り用溶融亚鉊メッキ鋼板の製造法の研究

新日本製鐵侏) 名古屋製鐵所 ○田本正一, 三木撤夫 関屋武之, 蒙本行

\section{1. 緒 言}

亜鉛メッキ鋼板は, 近年需要家における防錆対策強化策として, 家電製品や自動車用途に広く使用さ れるよらになってをた。乙の用途の桩大につれて, 複雑かつ厳しい加工に耐え得る成形性とメッキ密着 性が要求されるよらになってをた。本報では, $\mathrm{Ti}$ 添加極低炭素鋼（深絞り用溶融要鉛メッキ鋼板）につ らて,メッキ反応時のストリップ盜度（侵入板温）とメッキ浴中 $\mathrm{A} \ell$ 濃度の合金層生成及びメッキ密着 性に与える影響につんて報告する。

\section{2. 試験設備及び測定方法}

\section{2 - 1 . 試験設備}

当所実機ライン（連続溶融亜鉛メッキライン）

$2-2$. メッキ密着性評価方法

東京衡機・30トン深絞り試験機によって逆再絞りを 施し (Fig.1), 成形品側面のメッキ剥離状態在評価

$2-3$. 合金層厚の測定

電解剥離法により測定

\section{3. 結 果}

溶融亚鉛メッキでは, 溶融亜鉛と地鉄とが反応して $\mathrm{Fe}-\mathrm{Z}_{\mathrm{n}}$ の二元合金層を形成する。乙の合金層は脆弱な性質を有する為 厚く生成すると加工時のメッキ剥離の原因となる。それ故に, メッキ浴中に若干の $\mathrm{A} \ell$ 添加し, $\mathrm{Fe}-\mathrm{A} \ell-Z \mathrm{n}$ の三元合金層 を形成させ, 二元合金層の成長を抑える。 $\mathrm{T}$ i 添加極低炭素鋼

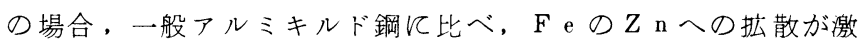
しい為に, 三元合金層の生成を促し二元合金層の発澾を坜制さ せる条件での操業が特に必要となる。

あるメッキ浴中 $\mathrm{A} \ell$ 濃度において、ストリップ盜度を上昇さ せると，三元合金層と共に二元合金層も成長してしまら。

しかし, $\mathrm{A} \ell$ 濃度を高めるととにょり三元合金の生成反応が 活発になり二元合金層形成が抑制される。即ち三元合金層によ るバリアー効果が認められる( Fig.2)。

また，様々な合金層厚のメッキ板のメッキ密着性を逆再絞り 試験により評洒したとてろ, 二元合金罾厚が $0.6 \mu \mathrm{m}$ 以下の時 密着性が良好てある事がわかった。

以上の結果から, 梁絞り成形にも甪え得る高レベルのメッキ 密着性を得るための, メッキ浴中のA $\ell$ 濃度と板温の最適操業 範囲が明らかになった（Fig.3）。
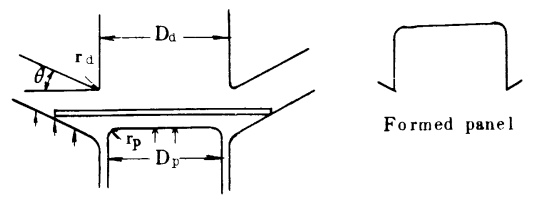

Fig.1 Forming methot of reverse redrawing.

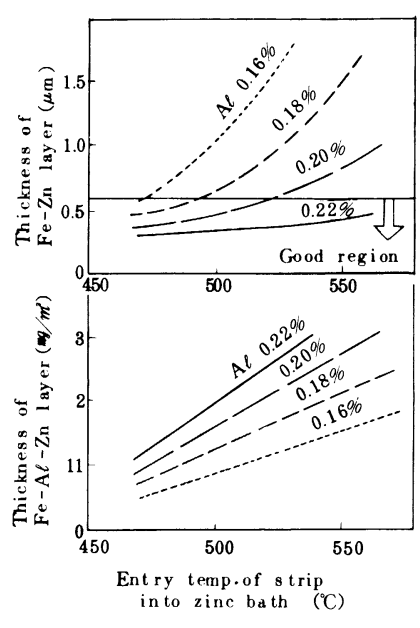

Fig. 2 Relation between alloy layer, entry temp of strip into zinchath and aluminum conc. of the bath.

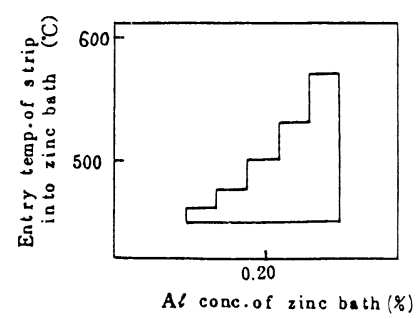

Fig. 3 Good region of athesion 
(466) 表面処理鋼板のパウリング性評価試験法

住友金属工業(蛛) 中央技術研究所

日産自動車 (侏) 工 袎 工 場
工博 林

氏原 新, 塩田哲郎

1. 緒 言

表面処理鋼板の剥離評価試験法については各種検討されて来ている。評価法として望まれるてとは各 涯表面処理鋼板の剥離挙動を適確にシミュレートしていることと定量的客観性を持っているてとである。 ててでは塗装系の表面処理鋼板を主体に上記の観点より剥離性評価試験法の検討，確立を行なった。

2. 皮膜剥離機構之試験用変形タイプの選択

剥離には大別して変形剥離（母材の変形に追従しきれず剥離）と摺動剥離（表面摩擦力による剥離）

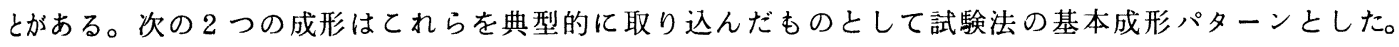

A）円筒絞り：縮みフランジ成形における変形追従性とダイス肩での擦れを伴う曲げ，曲げ戻し。

B）ビード付きハット成形：小肩半径でのくり返し曲げ，曲げ戻しと強い擦れを伴う成形。

3. 成形条件, 試験鋼種の決定

(1)工具寸法：母材の破断が起きない範囲で材料間の差が見られるような寸法の選択を行なった(Fig.1) (2)工具表面粗さ：Fig. 2 に示す如く剥離に重要な影響を及ほす要素で，番手を変えた研摩紙での目立 て(水平方向)により調整を行なうようにした。現行塗装鋼板としては 240 を基準条件とした。 (3)潤滑条件：滁布量の影響を調査し，作業性及び安定性から防錆油 D i p 後 1 時間たて掛け放置とした。 母材としては $0.7^{\mathrm{t}}$ の一般冷延鋼板及び 38 キロ級高強度鋼板を基準に選んだ。

4. 評価の定量化手法

Fig. 3 亿示す試験工程を取り, $W_{1}$ (成形前ブランク重量) - $W_{2}$ (成 形洗浄後の重量）を定量評価值の基本とした。重量測定は $5 / 100 \mathrm{mg}$ の 情度の直視天びんで行ない, 10 枚の平均值を取った。微小量の重量 差の測定である為試験片のバリ取り, 脱水, 乾燥の徽底が重要である。 本試験法の有効性を調へる為実部品のフロントフェンダーにて評価 し良好な対応があることを確認した。目視等による簡易試験法は本試 政法をべースにした較正を経た後それを用いることが出来る。
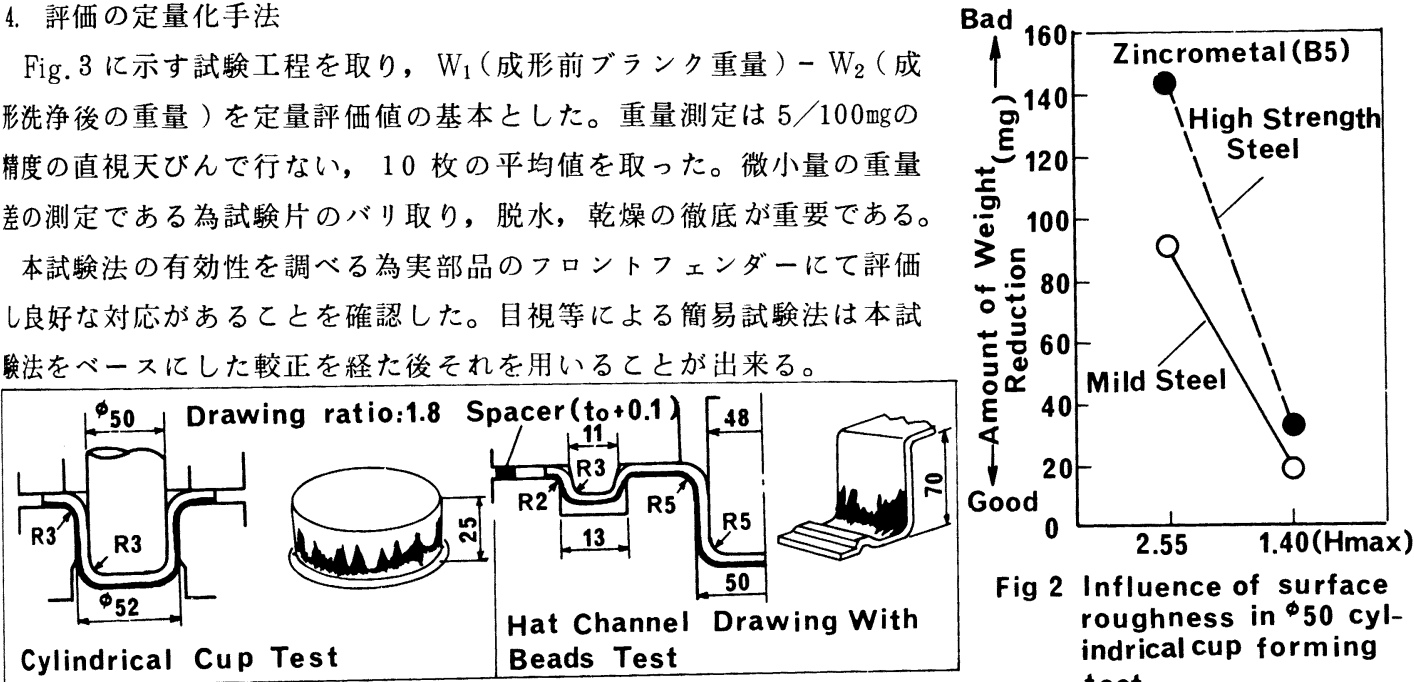

Fig 2 Influence of surface roughness in ${ }_{50} \mathrm{cyl}$ indrical cup forming test .

Fig 1 Shape and dimension of testing-dies

Blanking - Deburring $\rightarrow$ Degreasing $\rightarrow$ Drying $\rightarrow \begin{aligned} & \text { Measuring of } \\ & \text { the Weight }(W 1)\end{aligned} \rightarrow \begin{aligned} & \text { Coating of } \\ & \text { Lubricanting Oil }\end{aligned}$

Forming Degreasing $\rightarrow$ Drying in an Oven $\rightarrow$ Air Blowing

fig 3 Testing procedure of evaluating powdering phenomena. is conducted by alkaline solution)

参考文献 1） 林，坂根：日本鉄鋼協会第 102 回講演大会 67（1981）S976

2）大和康二他：日本鉄鋼協会第 102 回講演大会 67（1981）S981 
' $84-\mathrm{S} 468$

\section{（467）合金化溶融亚鉛めつき鋼板の表面特性に及ほす合金化度の影罊}

川崎製鉄(㧣) 技術研究所 $\bigcirc$ 竹内 優子 藤永 忠男

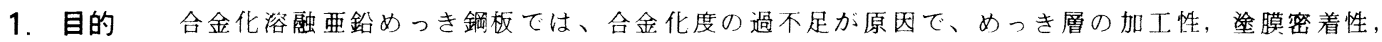
塗装後耐食性などの不良を起こすことがある。したがって、合金化度を用途に応じて適切に制御することが重 要であり、それによって品質の安定向上を達成することができよう。ここではその制御に先立ち、合金化度と 品質との関係を定量的に把握するため、めっき中 $\mathrm{Fe}$ 濃度 $(4 \sim 14 \mathrm{wt} \%)$ と表面諸特性との関係を調べた。

2. 実験方法供試材として低炭 $\mathrm{A} \ell$ キルド銟板を用い、めっき浴中 $\mathrm{A} \ell$ 濃度は $0.15 \mathrm{wt} \%$ とした。合金化板温 を $500 \sim 580{ }^{\circ} \mathrm{C}$ に変化させて、めっき量 $60 \mathrm{~g} / \mathrm{m}^{2}$, めっき中 Fe濃度 $4 \sim 14 \mathrm{w} \mathrm{t} \%$ の合金化溶融要鉛めっき試 験材を実機連続ラインで製造した。陚材めっき中Fe濃度は原子吸光法により分析し、各種合金相はX線回折に より同定した。また、表面特性試騃を以下のように行った。(a). 加工性 $180^{\circ}$ 密着曲げ試片外面におけるめ つき剥離量を螢光 $\mathrm{X}$ 線分析により求めた。 及び静電塗装を施し、碁盤目エリクセン・テ一プ剥離試験あるいはエリクセン塗膜俥裂試験を行って、一次密 着性及び二次密着性 $\left(50{ }^{\circ} \mathrm{C}\right.$ 温水 $240 \mathrm{H}$ 浸漬)を評価した。

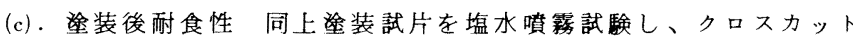
からのふくれ幅を湘定した。

3. 実験結果亡考察従来の見解と一致して、合金化度が高くな るにつれ、（1）加工性が劣化し（F i g. 1（A），（2）塗膜密着性が 向上し( Fig. 1（B），（3）装後耐食性が向上する( Fig.1(C) b (4) (1)〜(3)より総合評価すると、 Fe 濃度が約 $9 \sim 11 \mathrm{wt} \%$ の範用でバ ランスのとれた品質が得られ、加工性を重視する場合は 9 〜 $10 \mathrm{w} \mathrm{t} \%$, 望膜密着性あるいは装装後耐食性を重視する場合は 10 〜 $11 \mathrm{w}$ \% が望 ましいことがわかる。

$\mathrm{Fe}$ 濃度 $10 \mathrm{w} \mathrm{t} \%$ 以上における加工性の急激な低下は、台金の生成、 とくに「の増加に対応している( F i g. 2 )。合金化上昇に伴う堻膜 密着性の向上は、表層までの $\delta_{1}$ 結晶生成による塗膜接着面の増大と 投描効果にあり、また、塗膜下耐食性の向上は、塗膜密着性の向上 に加えて、 $Z \mathrm{n}$ 濃度隇少による電気化学的活性の低下に起因すると考 えられる。

\section{参考文献}

1）例えば、山田，ほか： 鉄と鐳， 69 (' 83 ), S 343

三吉，ほか：鉄と鎐， $66(' 80), \quad$ P 858
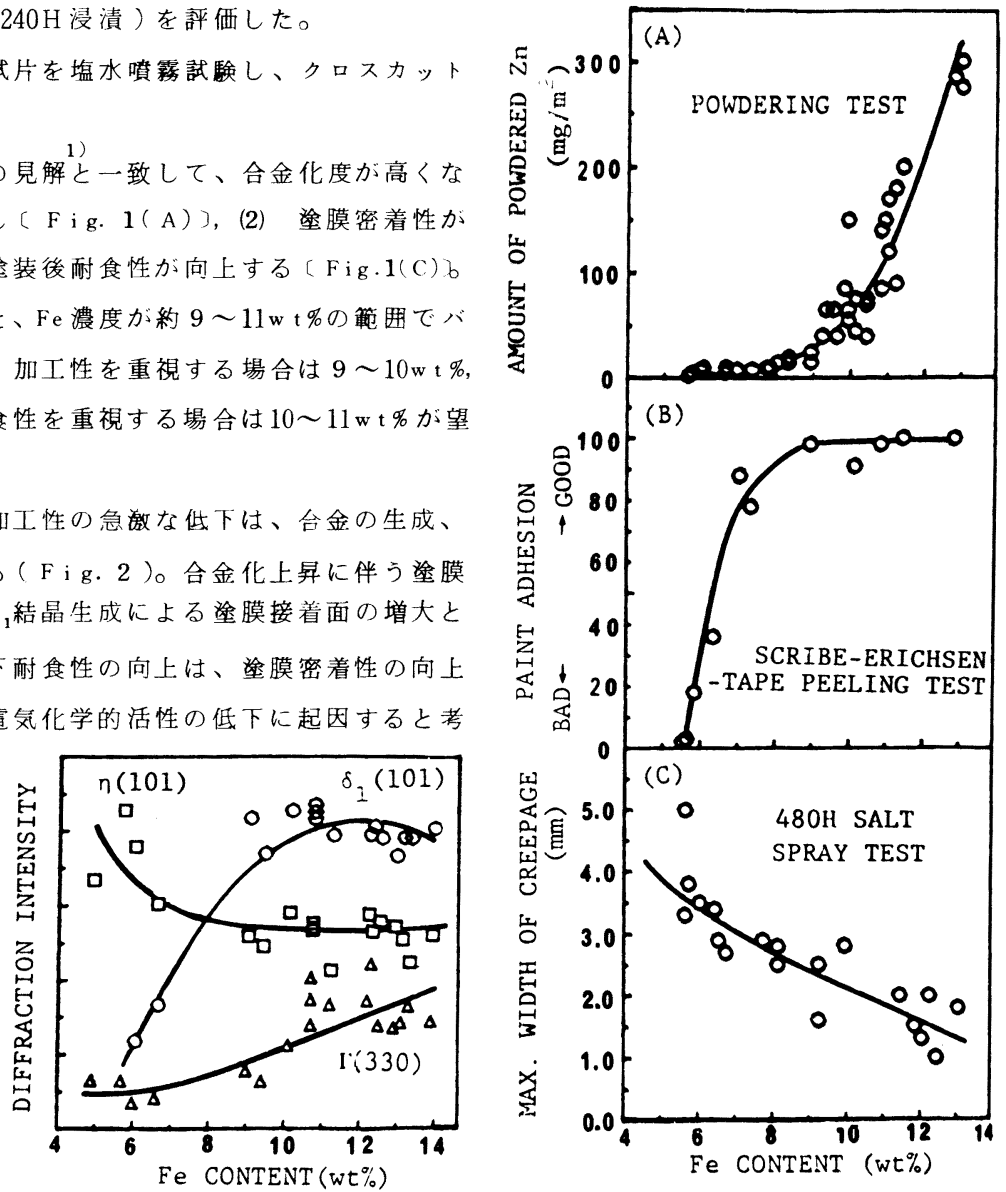

Fig.2 Relation between diffraction intensity of

Fig.l Relations between surface charactereach phase and Fe-content of galvannealed coating. istics and Fe-content of galvannealed coating. 


\section{(468) 溶融严鉊めっきラインにおける亜鉊転着防止用ロール材料の検討}

$\begin{array}{llll}\text { 新日本製鐵(侏) } & \text { 名古屋技術研究部 } & \text { 中山元宏 金丸辰也 東 光郎 } \\ & \text { 名古屋製鐵所 } & \text { 馬淵道夫 藤原俊朗 村上伸和 } \\ & \text { 第二技術研究所 } & \text { 吉田勝可 } & \end{array}$

\section{1. 緒 言}

溶融垔鉛めっを後, 連続熱処理炉により過時効処理を施す場合や冷却過程で比較的高温のまま通板口 ールに接触する場合には, めっを鋼板からハースロールや通板ロールに亜鉛が転着し, 製品々質・作業 性を損放る問題がある。亜鉛転着防止用ロール材料として適性材質を探索するとともに, 耐久性・最適 使用条件を検討したので報告する。

\section{2. 実験方法}

供試口ールと曲鉛めっを䤱板を強制的 に滑り回転させる方法の卓上型メタルピ ックアップ試験装置を試作し, 広範な材 料について耐メタルピックアップ性, 耐 久性の比較調查を行をい最適材質を探索 した。また炉内瑟囲気效果を調査し, 口 一ル材料としての奏用性を評価した。

(Fig.1, Tab.1)

\section{3. 実験結果}

（1）耐熱樹脂，七ラミックス，金属等 を含めを広範囲な材料についてロール適 性を調査した結果, フェノール樹脂含浸 アスベスト積層材が最適であった。

(2) 当材料につを, $\mathrm{O}_{2}+\mathrm{N}_{2}$ 雲囲気中で の耐摩耗性を試験した結果, 摩耗速度

$(\mathrm{W} \mu \mathrm{m} / \mathrm{d})$ \& $\mathrm{O}_{2}$ 濃度 $(\%)$ 亿依存する。

$$
\mathrm{W}=10000 \times\left[\mathrm{O}_{2}\right]^{1.5}
$$

これはロール表層のフェノール樹脂が 酸化分解するため, アスベスト層の摩耗 が促進されるととによる。（Fig.2,3）

（3）長期加熱による耐熱性試験を行な った結果, $0.01 \% \mathrm{O}_{2}$ 以下では表面硬度 - 寸法変化子安定しており（Fig。4）, 王縮強さや衝撃強さなどの機械的特性値 耐用性のあること在確認した。

\section{4. 結 果}

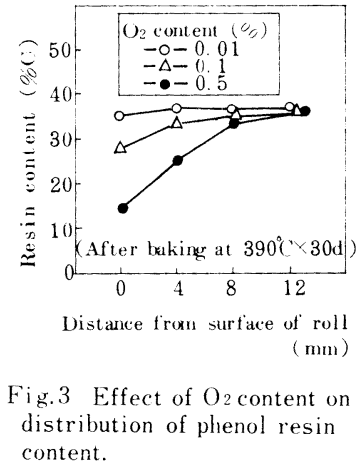

Tab. 1 Testing conditions.

\begin{tabular}{|c|c|}
\hline $\begin{array}{c}\text { Slipping } \\
\text { velocity }\end{array}$ & $0.5 \mathrm{~m} / \mathrm{min}$ \\
\hline $\begin{array}{c}\text { Average surface } \\
\text { pressure }\end{array}$ & $0.16 \mathrm{kgf} / \mathrm{cm}^{2}$ \\
\hline Temperature & $390^{\circ} \mathrm{C}$ \\
\hline Atmosphere & $0 \sim 1 \% \mathrm{O}_{2} \mathrm{in} \mathrm{N}_{2}$ \\
\hline
\end{tabular}
distribution of phenol resin content.
フェノール樹脂含浸アスベスト積層材は, 比較的高温で亜鉛め っを鋼板と接触する通板口ール用材料として優れた特性を有して おり, 適正条件で使用すれば甪用性・実用性は極めて高ら。

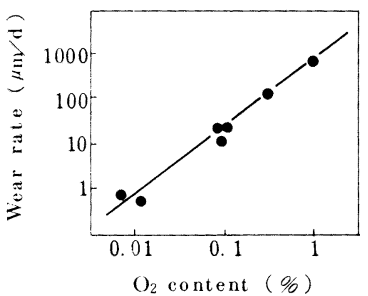

Fig. 2 Relationship between $\mathrm{O}_{2}$ content and wear rate.

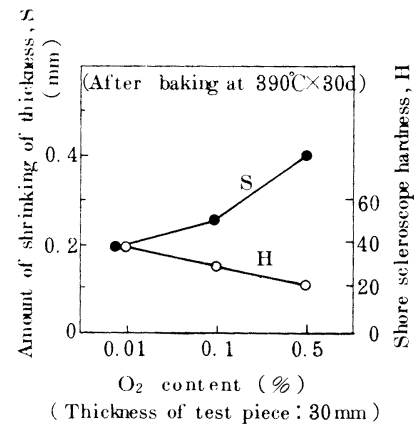

Fig. 4 Effect of $\mathrm{O}_{2}$ content on size change and surface hardness. 
（469）溶融要釷めっ去浴に発生するボトムドロスとAlての反応

$$
\text { 九州工大工学部考松良德大西正己 }
$$

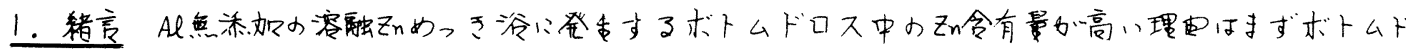

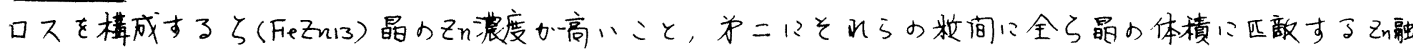

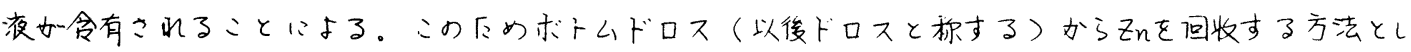

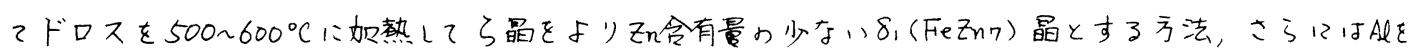

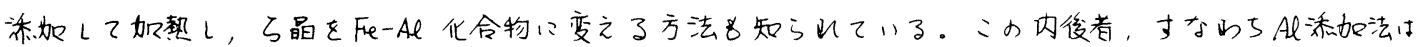

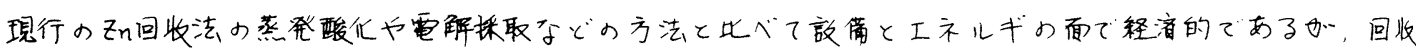

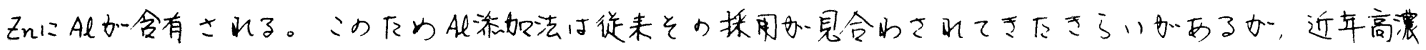

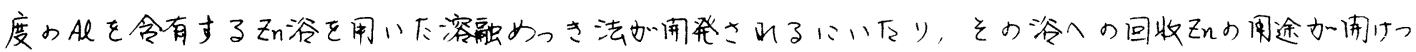

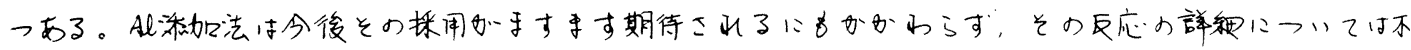

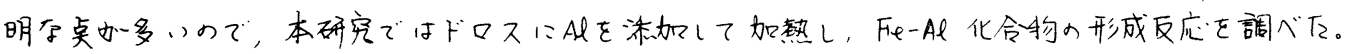

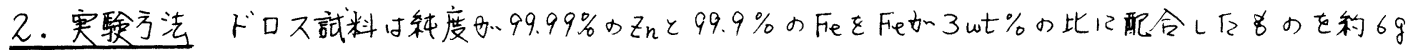

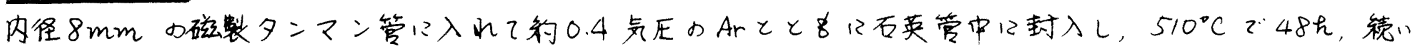

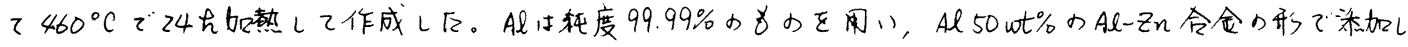

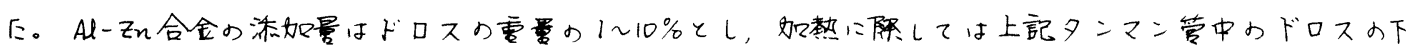

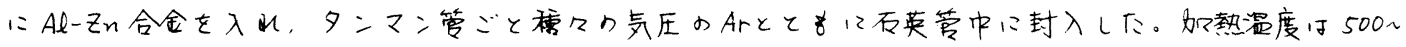

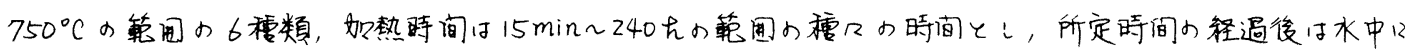

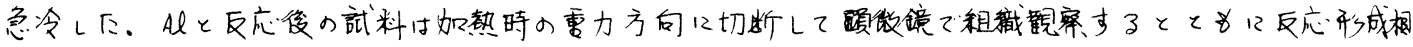

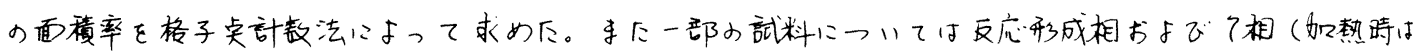

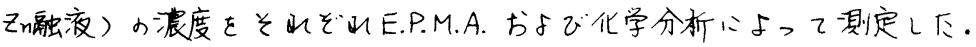

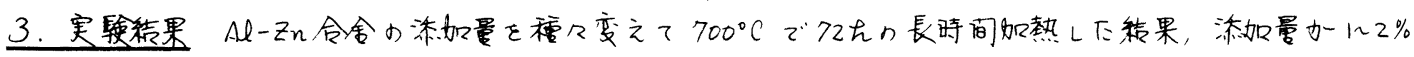

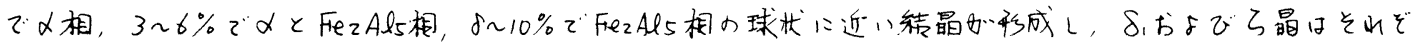

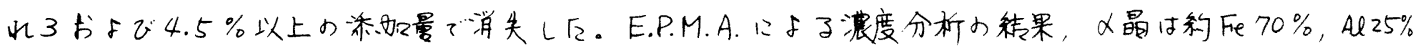

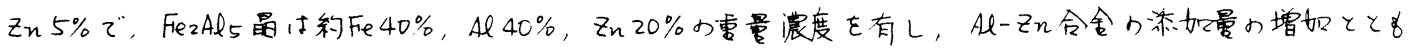

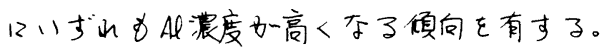

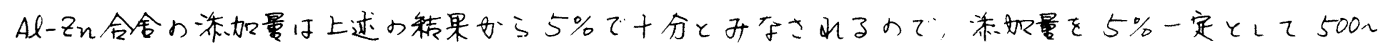

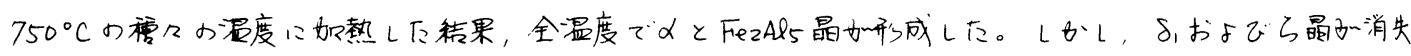

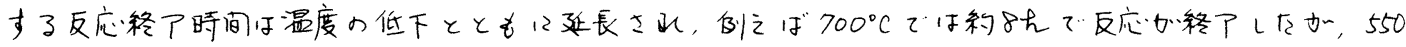

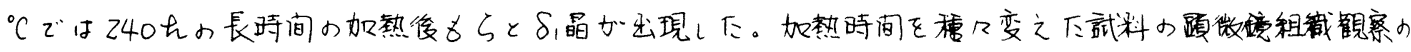

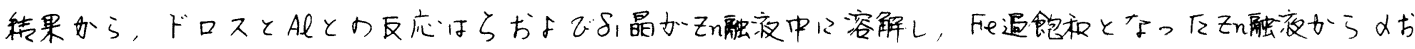

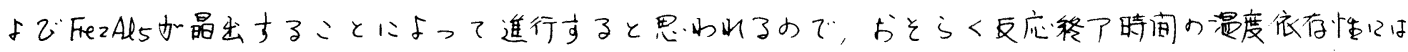

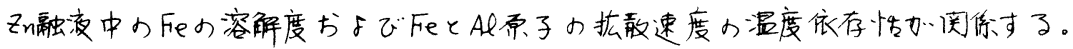

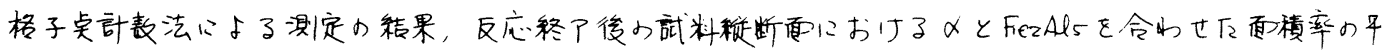

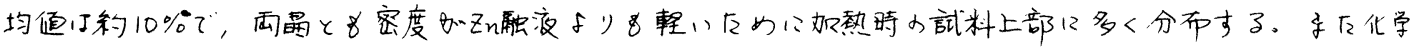
分析の綞果，反忘䅂後の广(

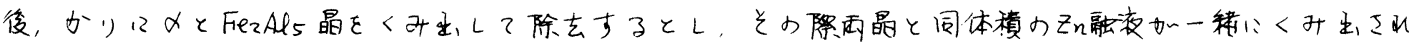

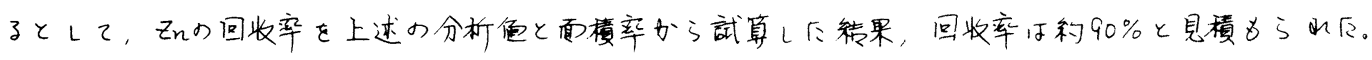




\section{（470）溶融监鉛めっき材のZn-Co系電気めっき塗装前処理の検討}

東洋鋼鈑㑣) 技術研究所○市島真司 中本哲男 神田勝美

\section{1. 緒 言}

近年、外装用途に高耐食性塗装鋼板への要望が高まり、塗膜に塩化ビニル樹脂を用いた場合の、下地 鋛板の選択が重要な問題となってきた。下地鋼板として溶融亜鉛めっき鋼板（H.D.G）が、多く用いら れているが、塗装後の耐食性が劣るため、種々の塗装前処理が施てされている。代表的な淕装前処理と しては、リン酸要鉛系処理、クロメート処理などがあるが、まだ十分な加工性、耐食性ば得られていな い。今回、H.D.Gの塗装前処理として、Zn-Co系電気めっきについて検討したので報告する。

\section{2. 実 験 方 法}

2.1 供試試料

実験に用いたH.D.Gは、ノンスパングル，ノンク ロメート処理板で、Zn目付量が両面で $180 \mathrm{~g} / \mathrm{m}^{2}$ のも のを用いた。

\section{2 処理工程}

前処理条件、めっき処理条件を種々検討した結果、

Fig. 1 亿示す製造プロセスに従って処理した。

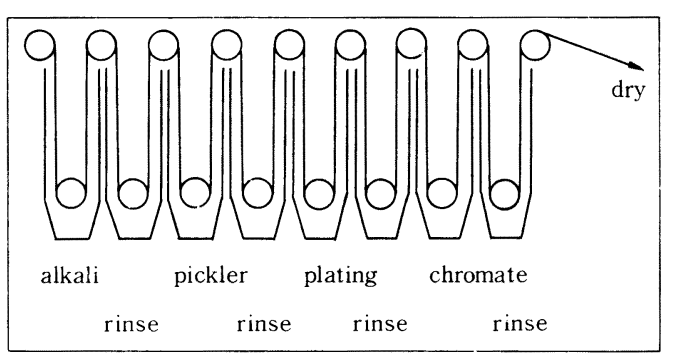

Fig. 1 Process of $\mathrm{Zn}$-Co electroplating

\section{3. 結 果 及び 考 察}

\section{1 前処理の影響}

H.D.G 材の表層には、 $\mathrm{ZnO}, \mathrm{A}_{2} \mathrm{O}_{3}$ などの強固な酸化皮膜で覆われており、との酸化皮膜は、 $\mathrm{Zn}$ 一 Co電気めっき皮膜の密着性に悪影響を及ぼし、 $\mathrm{H}_{2} \mathrm{SO}_{4}$ 酸洗では容易に溶解せず、部分的なピッティング現 象を示す。アルカリ電解処理（A 処理）により、酸化皮膜は除去でき、均一な $\mathrm{n}$ 表面が得られる。

\section{2 めっき処理条件}

$\mathrm{Zn}$-Co電気めっきにおいては、浴組成に比べ、Co析出量 が少ない異常型の析出傾向を示す。Co析出の電流効率は、 電流密度、擋拌の影響を大きく受け、電流密度が高い程、 摚拌が弱い程、Co析出の電流効率は大きくなる。(Fig. 2) めっきの密着性は、通電量及び $\mathrm{pH}$ の影響を受け、Znめっ き量として、30 g/ $\mathrm{m}^{2}$ (片面) 以下、 $\mathrm{pH}$ が 6.0 以下で、 良好な密着性が得られる。

\section{3 塩ビ鋼板の特性}

塩ビ鋼板の耐食性は、めっき皮膜中のCo含有量に依存し Co量が $0.5 \mathrm{mg} / \mathrm{dm}^{2}$ 以上になると、他の処理に比へて塩ビ膜の 八クリ幅は少なく、耐食性が優れている。Co量が $15 \mathrm{mg} / \mathrm{dm}^{2}$ 以上になると加工性が劣る傾向にある。クロメート処理と 組合せることによって耐沸水性が向上する。

てれらの点について、EPMA，ESCA，AES等に より考察した。

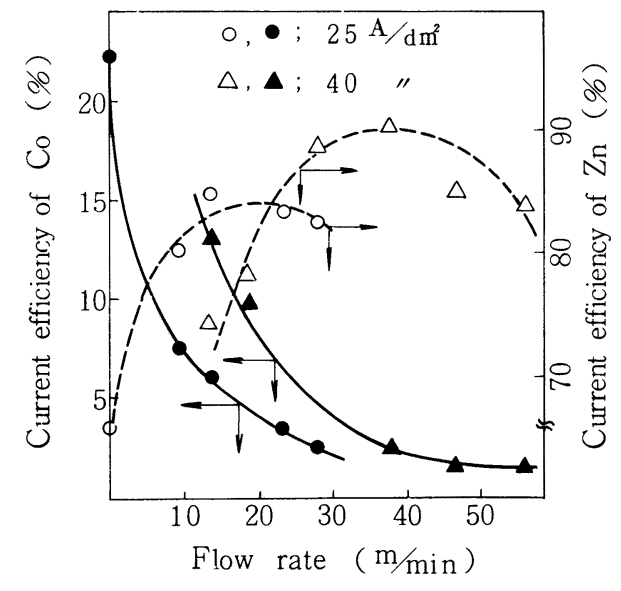

Fig. 2 Effect of flow rate on the Current efficiency of $\mathrm{Zn}, \mathrm{Co}$ 
1. 緒言

合金化溶融要鉛めっき鋼板を原板としたプレコート鋼板を切断した場合、切断線に浻ってエナメル ヘアーと称する塗膜はく離を発生するととがある。とれは塗膜のみがはく離したものではなく、切断 時のひずみによってめっき層から破壊したものである。ててでは合金化溶融亜鉛めっき鋼板のめっき 圈の鉄濃度および切断時のクリアランスを変化させ、エナメルヘアーにおょぼす影響を調べた。

2. 実 験 方 法

表 1 亿示す合金化溶融悪鉛めっき 鋼板を使用した。合金層の鉄濃度は $3.6 \sim 16.3 \%$ の間で合金化度を 6 通 りに変化させた。鋼板を、リン酸亜 鉛処理した後、ポリエステル系塗料

Table 1 Material
\begin{tabular}{|c|c|c|c|}
\hline & Thickness & Coating weight & Fe content \\
\hline $\begin{array}{l}\text { Galvannealed } \\
\text { steel sheet }\end{array}$ & $0.7 \mathrm{~mm}$ & $\begin{array}{c}45 \mathrm{~g} / \mathrm{m}^{2} \\
(\text { each side) }\end{array}$ & $3.6-16.3 \%$ \\
\hline
\end{tabular}

を乾燥塗膜厚 $25 \mu \mathrm{m}$ 狙いで塗装し、焼付けを行った。

エナメルヘアーの評価は、クリアランスを容易に変え得る為、打拔きによって行った。ポンチ径は $14 \mathrm{~mm}$ ○とし、ダイス径を14.15 mm 塗膜をテーピングによってはく離し、幄膜はく離部の面積を測定した。

3.実 験 結 果

(1) 原板のめっき㲏の 鉄濃度が高くなる につれて、エナメ ルヘアーの発生程 度は大きくる。 これは鉄濃度が高 くなると、亜鉛一 鉄合金殿が脆化し、 母材の変形に追随 しにくくなるため と考えられる。

(2) 打抜きクリアラン スが小さい程、エ ナメルヘアーの発 生程度は大きい。

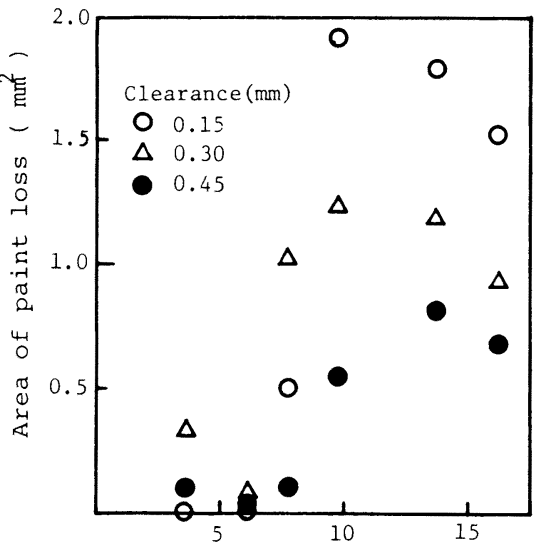

Fe content ( $\left.\frac{o}{5}\right)$

Fig.l Effect of $\mathrm{Fe}$ content of plated layer on paint loss

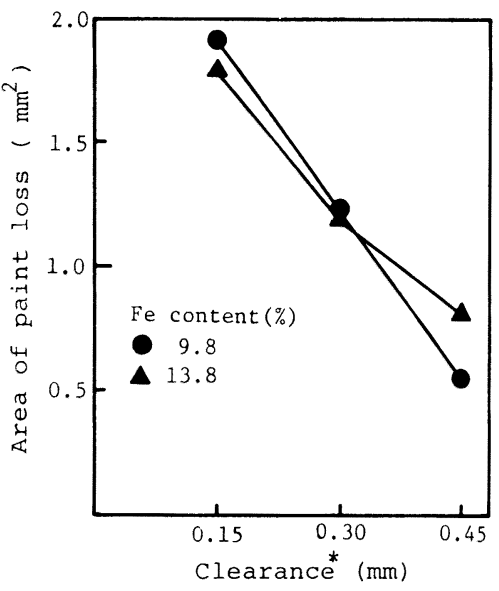

Fig.2 Effect of clearance on paint loss * TOTAL CLEARANCE BETWEEN PUNCH AND DIE

これは、クリアラ

ンスが小さい程打抜き時のひずみの量が大きく、また端面からのひずみがおよぶ範囲が広いためで あると考えられる。

( 参考文献)

1) K. PEARCE\&A. A. MAZHAR: METALS TECHNOLOGY, JULY 1976 , P $338 \sim 343$ 


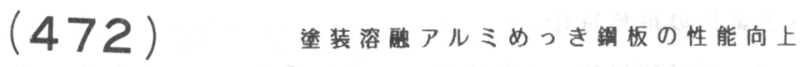

日新製制市川究所和泉圭二福本博光 山吉和既村上敏則

1. 粕 言

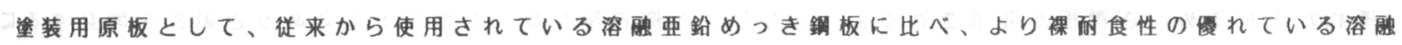
アルミめっき銿板を使用することにより、きわめて良好な結果が得られることを確想した。そこで我々はさ らに塗装溜融アルミめっき鋼板の性能向上(エッチクリープ、及び湿潤環境で発生する赤錆の隇少)を計る ため、下塗り塗料の面から検討した。その結果、著しい协果をあげることができたので報告する。

2. 実娩方法

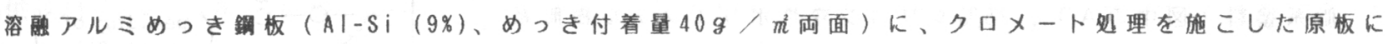
「ab|e. 1 に示す塗料を下塗り塗料として塗装焼付け(塗膜厚さ $5 \mu$ )した後、上塗り塗料としてポリエステ

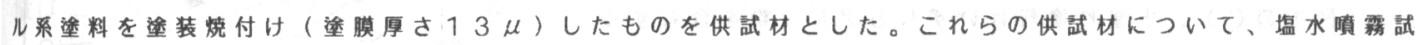

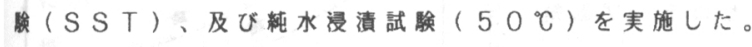

\section{3. 実験結果}

(1) S S T の結果をFig. 1 K示す。体質䫀料として炭酸力ル シウムを使用することにより、いずれの防錆碩料において も、良好な結果を示し、特にエッチクリープの隇少が顥著 であった。さらに、防錆䫀料との組合せにおいては浴出物 のPHの高いものの方が、やや良好な結果を示している。

(2)純水浸漬試騃の結果、Photo.1 1 示すように、体質顔料 として炭酸カルシウムを使用したものは、カット部よりの 赤錆の発生がきわめて少なく、良好な結果を示した。

\section{4. 考察}

S S Tでは糸状腐食と推察される部分が認められ、この先

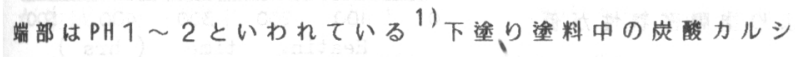
ウムにより、腐食先端部のPHが中和され、低PH化を防き腐食 進行が抑制されるのではないかと考えられる。また、めっき 表面にC $\mathrm{Ca}^{2+}$ の吸着が多量に䛱められ、そのCa ${ }^{2+}$ の防護作用も あると考えられる。一方、粴水漫漬試睮では、露出した Fe素 地表面が炭酸カルシウムにより、弱アルカリ側に保持される ため、Fe表面に耐食性良好な被膜が形成され、赤錆の発生が きわめて少ないのでないかと考えられる。

5.まとめ

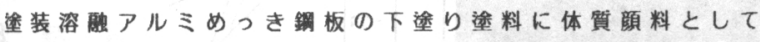
岑酸力ルシウムを使用することにより、きわめて良好な結果 を得ることができた。

参考文献 (1)、G.H.Hoch. Proc. Intern. Conf. Local iced. NACE-3(1974)

\begin{tabular}{|c|c|c|c|}
\hline No. & Resin & Extender pigment & Inhibltive pigment \\
\hline 1 & \multirow{4}{*}{$\begin{array}{l}\text { EDoxy resin } \\
+ \\
\begin{array}{l}\text { Urea resin } \\
\text { (E) }(x)\end{array}\end{array}$} & $\mathrm{TiO}_{2}$ & \multirow{4}{*}{$\begin{array}{l}\text { Chromate } \\
\text { pigment } \\
\text { (A) (B) (C) (D) } \\
\text { (20wtx) }\end{array}$} \\
\hline 2 & & $\mathrm{BaSO}_{4}$ & \\
\hline 3 & & $\mathrm{SiO}_{2}$ & \\
\hline 4 & & $\mathrm{CaCO}$ & \\
\hline
\end{tabular}

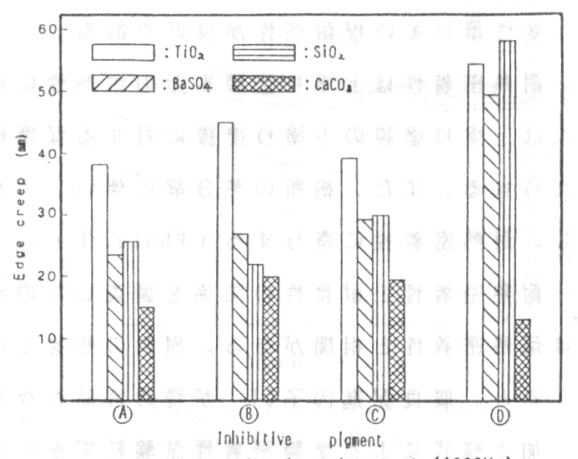

Fig. 1 Result of salt splay test $(1000 \mathrm{Hr})$

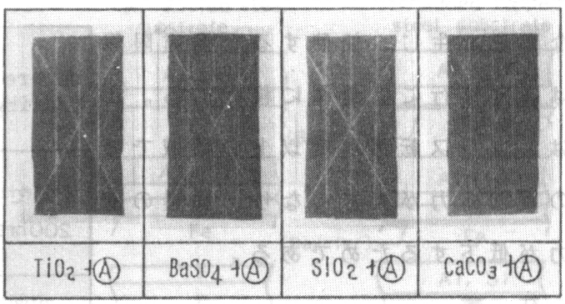

Phot. 1 Result of immersion test in pure water at $50^{\circ} \mathrm{C}(240 \mathrm{Hr})$ 
（473）透装アルミめっき制板の耐熱特性

日新製鎆株市川研究所

増原憲一山吉和雄若林耕二 福本博光咔本敏江

1. 緒言

溶融アルミめつき鋼板は、マフラー用部材や石油ストープの部材等に使用されてきた。近年、より耐食性 に瀀れたアルミめつき銅板が要求されるようになり、有譏被覆を施した塗装アルミめつき銅板を開発するに 至ったので、本開発品の耐熱塗膜密着性および柇食性について調查した結果を報告する。

2. 実験方法

(1) 供試材原板：溶融アルミめつき鋼板, めつき付着舅 $40 \mathrm{~g} / \mathrm{m}$, 板厚 $0.6 \mathrm{~mm}$ 前処理：クロメート処理 塗料：下塗りエポキシ樹脂系塗料。上塗りポリエステル樹 脂系塗料（図中のA），25\%シリコン変性ポリエステル樹脂系 塗料（図中のB），40\%シリコン変性ポリエステル樹脂系塗料

(図中のC)，上塗り塗料はいすれもアルミ粉を含有する。

(2)調査項目 $\mathrm{a}$, 加熟試騒後の塗膜密着性試騃：七ロテープ剥離 b. 加熱試験後の浸漬試験: Cl ${ }^{-} 5000 \mathrm{PPM}\left(\mathrm{NH}_{4} \mathrm{Cl} ; 80^{\circ} \mathrm{C}, 48 \mathrm{Hr}\right.$

C . 加工様式による塗脱密着性試煥: 加工後 $250^{\circ} \mathrm{C}, 50 \mathrm{Hr}$ 加熟 3. 実験結果及び考察

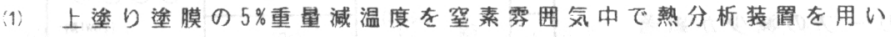
て調查した結果、Aは $210^{\circ} \mathrm{C} 、 \mathrm{~B}$ は $248^{\circ} \mathrm{C} 、 \mathrm{C} は 270^{\circ} \mathrm{C}$ でりシリ コン変性量が多い程耐熱性が良好である。

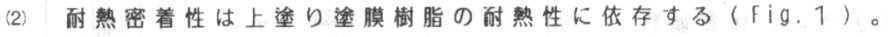
これは上塗り塗膜の下塗り塗膜に対する保護作用の差に依るものと 考えられる。また、樹脂の熱分解に伴い、アルミ粉が層状、密に沈 着し、耐熟密着性に奇与する(Photo.1)。

(3)耐熱密着性と耐食性の関係を調查したのがFig，2である。耐食 性は利熟密着性と相関がある。樹脂の熱劣化により塗膜密着性が低 下すると、腐食促淮因子Cl”が浸透容易となり、耐食性が悪くなる。 (4)加工様式による塗膜密着性試験絬果を $\mathrm{Fig} .3$ に示す。加熱前の

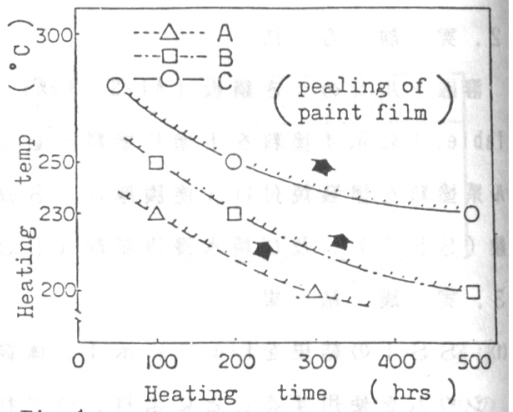

Fig.1 Adhesion test of paint film after heating. (erichsen test)

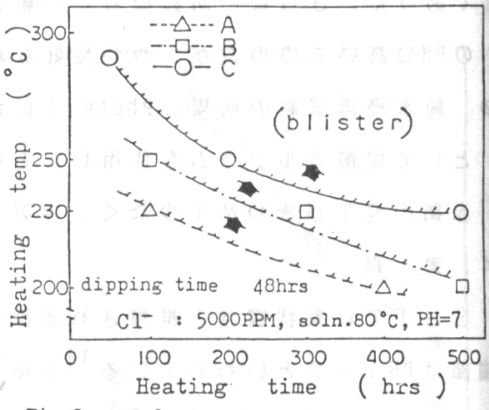

Fig.2 Relation of heat degradation of paint film and corrsion resistance.

塗膜剥離は、張出し変形域では生じないが、樎みフランジ変形のよ

うな変形で生じ、加熱すると剥離限界 線はほほ平行に低歪側に移行する。こ れは、ガラス転移温度以上の領域で塗 膜の収縮応力が大さくなり、塗膜の密 着力が低下するためである。

4. 結言

塗装アルミめつき銅板の耐熱塗膜密 着性は、塗膜樹脂の耐熱性に依存し 耐食性と良い相関を示す。

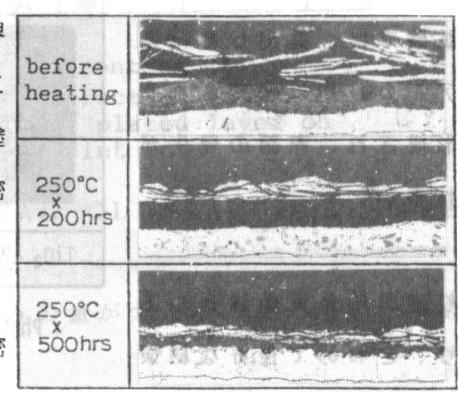

Photo. 1 Change of cross section of paint film (sample:c)

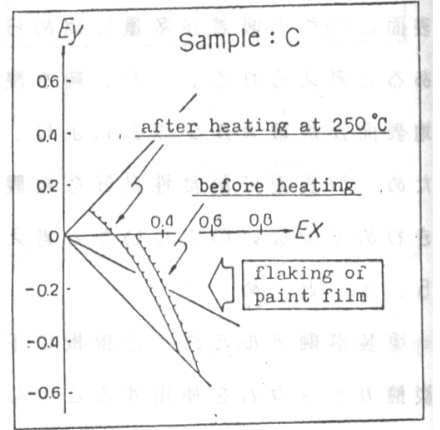

Fig. 3 Adhesion of paint film at forming limit diagram. 


\section{(474) 加熱時におけるAlめっき鋼板のめっき層合金化におよぼす

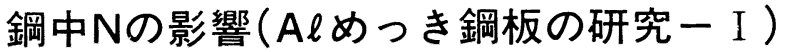

新日本製鐵(侏) 中央研究本部 日干 元 森田矩夫 矢部克彦

板東誠志郎 ○沼倉行雄

1. 緒 $\overline{\overline{\bar{n}}}$

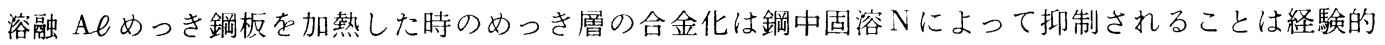
に知られているが，その抑制機構は十分には明らかになっていない。本報では原板鋼中固溶 $\mathrm{N}$ 量の異な る溶融 $\mathrm{A} \ell$ めき鋼板を種々の温度, 保持時間で加熱した時のめっき層の相変化についてと, 具体的に固 溶Nがどのような影響をおよぼしているかについて検討した結果とを報告する。

\section{2. 実験方法}

供試材である溶融 $\mathrm{A} e$ めき鋼板の原板は $\mathrm{A} e$ キルド 鋼, キャップド鋼, $\mathrm{N}$ 添加キャップド鋼であり, 固溶 $\mathrm{N}$ 量はこの順に多い。それぞれの原板の化学組成を Table. 1 に示す。

種々の加熱条件で生じるめっき部合金層の相の同定を 主にX線回析で行った。次に具体的に鋼中固溶 $\mathrm{N}$ がどの ような影響をおよぼしているのかを調べるために T E M， E D A X，E E L S を用いて実験を行った。

\section{3. 実験結果}

Fig.1 (a)(b)に原板がそれぞれ A $\mathrm{A}$ キルド鋼， N 添加キ ヤップド鋼である A $＼mathrm{~ め っ き 鋼 板 の め っ き 部 合 金 層 の 恒 ~}$ 温相変化マップを示す。両者の間には明らかに相違が認 められる。この原因を考察するために，500 た時の合金化の過程を調べた結果を模式図にしたのが Fig.2である。Fig.2 に示したように原板が A 鋼のものでは，まずH相と地鉄との間に $\theta$ 相 $\left(\mathrm{FeAl}_{3}\right)$ が生成するが原板が $\mathrm{N}$ 添加キャップド鋼のものでは $\theta$ 相 は生成せず H相が $\mathrm{A} e, \mathrm{Si}$ 層側から M相に変化する。こ れらのことは，前者では $\mathrm{H}$ 相と地鉄との間で $\mathrm{Ae}, \mathrm{Fe} の$ 相互拡散が起こっているが，後者ではそれが起こらない ことを示すものである。従来，溶融 $\mathrm{A} e$ めっき鋼板にお いては拡散を防止するのは固溶 $\mathrm{N}$ ，あるいはM相といわ れてきたが，Fig.2の結果によれば H相と地鉄との境界 に拡散を防止するバシヤーがあると考えられたので，そ れらの境界の抽出レプリカを作製し T E M で観察した結 果, $\mathrm{A}$ l $\mathrm{N}$ と同定できる緻密な薄膜状物質が確認された。 3. 結 言

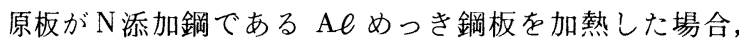
$\mathrm{A} \ell, \mathrm{Fe}$ の抎散が抑制されるため合金化が遅いが，その 原因は $\mathrm{M}$ 相ではなく $\mathrm{H}$ 相と地鉄との界面に存在するバリヤー層であることがわかった。
Table.l Chemical composition of substrate steel

\begin{tabular}{|l|c|c|c|c|c|c|c|}
\hline & $\mathrm{C}$ & $\mathrm{Si}$ & $\mathrm{Mn}$ & $\mathrm{P}$ & $\mathrm{S}$ & $\mathrm{T} . \mathrm{A} \boldsymbol{l}$ & $\mathrm{T} . \mathrm{N}$ \\
\hline A $\ell$-Killed & 0.042 & 0.03 & 0.24 & 0.022 & 0.019 & 0.020 & 0.0020 \\
\hline $\begin{array}{l}\text { capped } \\
\begin{array}{l}\text { N-added } \\
\text { Capped }\end{array}\end{array}$ & 0.039 & 0.039 & 0.22 & 0.011 & 0.011 & $<0.002$ & 0.0023 \\
\hline
\end{tabular}
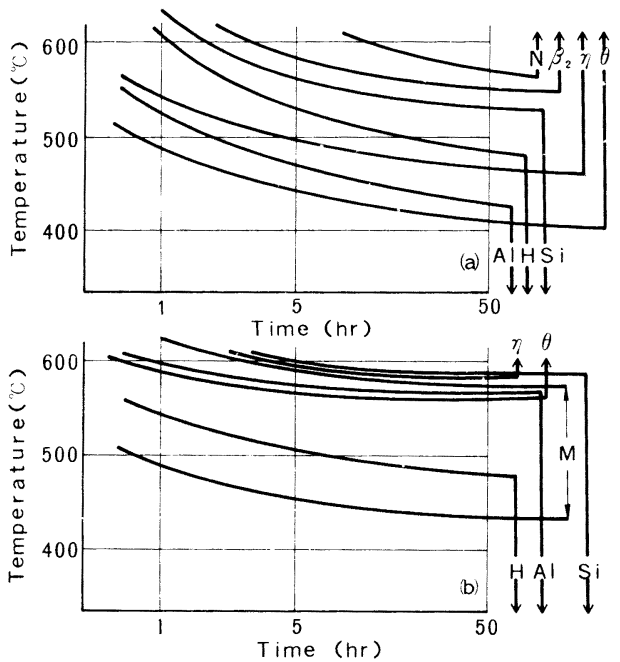

Fig. I TTT diagram of alloyed layer (a) Al-killed steel substrate (b) $\mathrm{N}$-added capped steel substrate

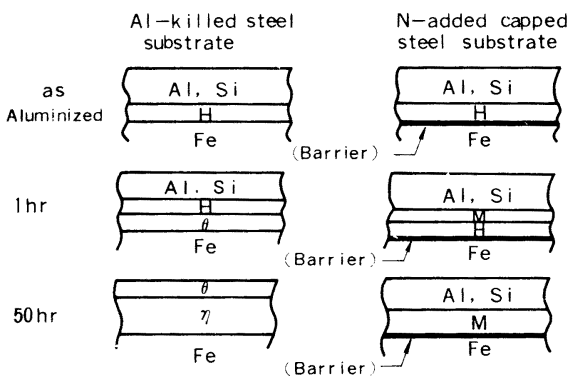

Fig. 2 Schematic representation of Alloying process at $500^{\circ} \mathrm{C}$ 
' $84-\mathrm{S} 476$

（475）＼cjkstart粉末法によるアルミニウム被覆鋼板の製造法と品質

川崎製鉄㧣 技術研究所 久保浩士り小林繁

浜田元春（現本社）原田俊一

市田敏郎入江敏夫

\section{1. 緒言}

粉末法は鋼板に金属粉末を層状に付着させ，压延と熱処理とを施すことを特徵とする鋼板の金属被覆 方法である。この方法ではアルミニゥムの融点末満の温度で熱処理を行なうので, 本来アルミニゥム膜 之鋼板との界面に硬くてもろい合金首が生成し難く, 純アルミニゥムの被覆に適している。亜鉛予備め っきによるアルミニゥム膜密着性向上と二回圧延法による連続製造法の検討 ${ }^{1)}$ に引続き温間一回圧延法 の検討を重ね, 同法による板幅 400 m , 板厚 0.35 0.8m の製品の連続製造法を確立した。

\section{2.一回圧延法による製造法}

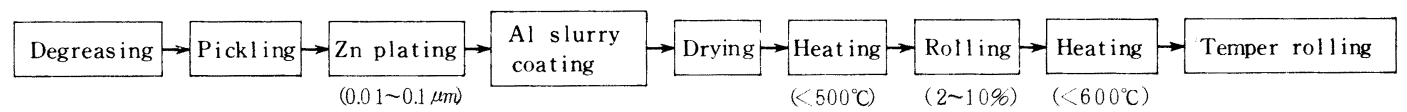

Fig. 1 Production process of aluminum coated steel sheet

\section{3 . パイロットラインによる試作結果}

図 1 の脱脂から圧延, 加熱までの工程を連続して処理できるパイロットラインを用い板幅 $400 \mathrm{~mm}$, 板 厚 $0.35 \sim 0.8$ m の鋼帯の両面にアルミニウムを被覆する連続製造法を確立した。本製造法の特徴は(1)口一 ルコーターでアルミニウムの水スラリーを塗布するので塗布工程が安定しており, 板幅 400 m の全幅に わたり膜厚が均一になる。(2)一回圧延法では加熱（<500 C 後ただちに温間圧延するので粉末アルミニ ウムがち密な膜になりやすい。(3)工程が単純である。

\section{4. パイロットライン試作品の品質}

(1)一回圧延法製品の膜密着性は二回压延法のものと同様に良好であった。 (2)膜厚分布が良好であっ た。(図 2 ) (3)膜の純度がよくち密であるため, ブライトスキンパス材では光沢度がよく, 赤外線反射 率はアルミニゥム板のものとほぼ同じであった。

(表 1)

\section{5 . 用途}

従来のアルミニウムめっき鋼板, アルミニウム 板の用途に加え, 純アルミニウムと鉄とによる新 しい機能材料としての用途等適用範囲が広い。

\section{6.まとめ}

亜鉛予備めっきによりアルミニウム膜密着性を 著しく向上した粉末法アルミニウム被覆鋼板（板 幅 $400 \mathrm{~mm}$ ）を温間一回压延法で連続製造する方法 を確立した。

参考文献

1)鉄と鋼 66 (1980), p.868

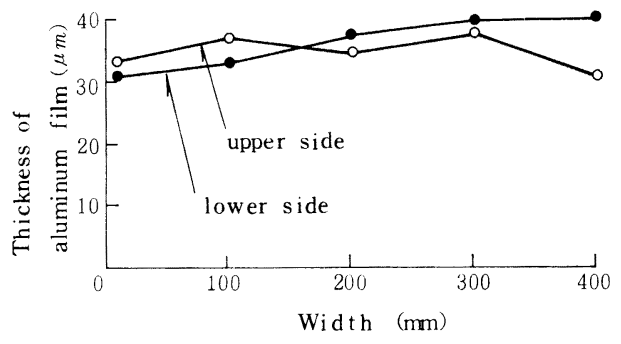

Fig. 2 Variation of aluminum film thickness on steel sheet

Table 1 Reflectivity of inf ra-red ray

\begin{tabular}{|c|r|r|r|r|c|}
\hline Wave length $\left(\mu_{m}\right)$ & \multicolumn{5}{|c|}{ Reflectivity (o) } \\
\hline Al coated steel sheet & 2 & 5 & 10 & 20 & 30 \\
\hline Al sheet & 95 & 96 & 96 & 97 & 98 \\
\hline
\end{tabular}


アルミめつを鋼板の簡易剥離試験方法の検討

(溶融アルミめつき銅板の成形性 V)

\begin{tabular}{|c|c|c|}
\hline 日新製鋼(株) & 査研究所 & ○山田利郎 \\
\hline & 阪神研究所 & 竹添明信 \\
\hline
\end{tabular}

\section{1. 緒 言}

溶融アルミめつき鋼板 ( $\mathrm{A} \ell-\mathrm{Si}$ 系) の加工によるめつき層の剥離は、主として円筒の多段絞りによつて判定さ れてきた。最近各種の表面処理鎘板の加工による表面損傷のシミュレーションテストがいくつか報告されている。 そこでアルミめつき鋼板の剥離を簡単にシミュレートする方法について検討した。

2. 簡易剥離試毚方法の選択

アルミめつき鋼板の剥離は、最初に压絔変形を受けその後引張り変形を受けると発生する゙りのて、ダィス肩部

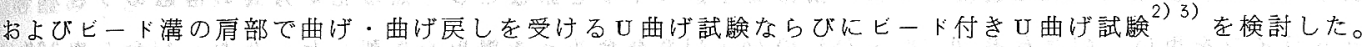

ビート付きU曲げ試験では、ビード溝の肩半径を小さくするとポンチ肩破断が生じ、肩半径を大きくすると䈆 しい加工で発生する剥離を判定するには加工度が不足することが判つた。しかしU曲げ試験（图１）では、ダイ ス肩半徍 $(r d)$ をさくしてもポンチ肩破断は発生せず、さらにタイス角度 $(\theta)$ をさくすることによつて、よ

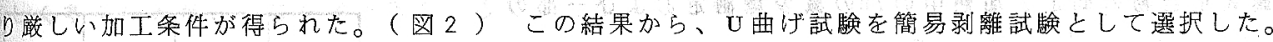

3. U 曲げ試験による簡易剥離試験機の試作

U曲げ武験では、板押え力を $500 \mathrm{kgf}$ から固定式しわ押えによる0 kgf まで変化させても、剥離の状態が変

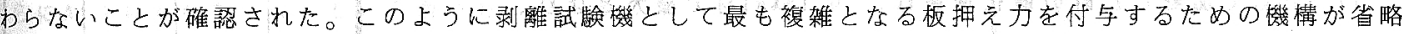
可能となつたので、手動油压ジャッキでポンチを駆動する軽量・小型の簡易剥離試験㙨を試作した。

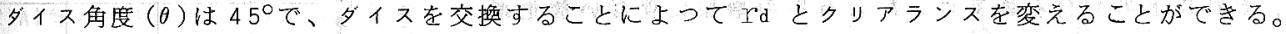

\section{4. 剥離試験結果}

リムド鋼を素材とし、同ーコイルでめつき付着量を片面で 38 ～ $73 \mathrm{~g} / \mathrm{m}^{2}$ と変化させた板厚 $1.0 m m$ の実ライン製造アルミめつき鋼板を、簡易剥離試驗 に供した。 $\mathrm{d}=0.5$ では、付着量が $50 \mathrm{~g} / \mathrm{m}^{2}$ を越えると剥離が発生した。 の結果は、前報 ${ }^{4)}$ の内筒の直接 3 回絞りで発生する剥離と良い対応を示し た。(写真 1) [文献了1)竹添他：日新技報， M6 40 ('79) P.21 2) 林他 ; 鉄と鋼，67('81) S976 3) 本田他; 鉄と鋼 68 ('82) S 1100

4)川瀬他；鉄と鋼 69('83) S 402

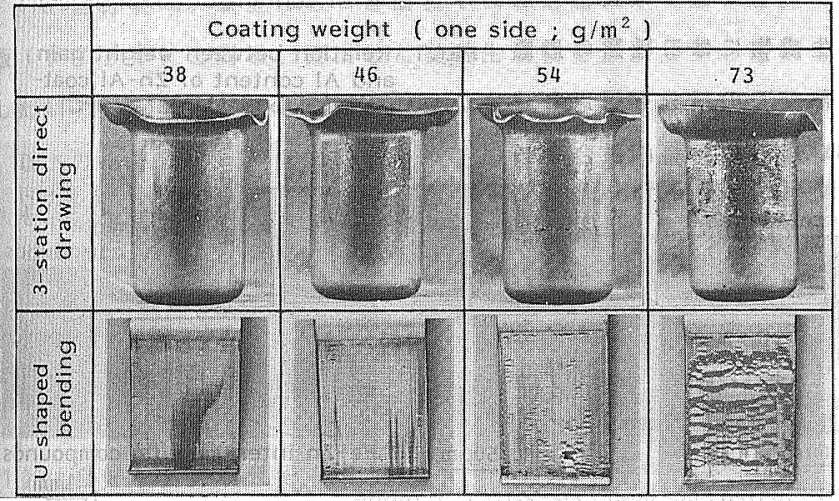

Photo. 1 Comparison of appearance after $\mathbf{U}$-shaped bending test $\left(r_{d}=0.5 \mathrm{~mm}, \theta=45^{\circ}\right)$ and 3 -station direct drawing test ( $\phi 90$ blank $\rightarrow \phi 50$ cup $\rightarrow \phi 39$ cup $\rightarrow \phi 30$ cup )
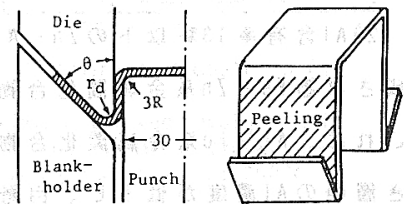

Fig. 1 U-shaped bending test for evaluating the peeling of coated metal

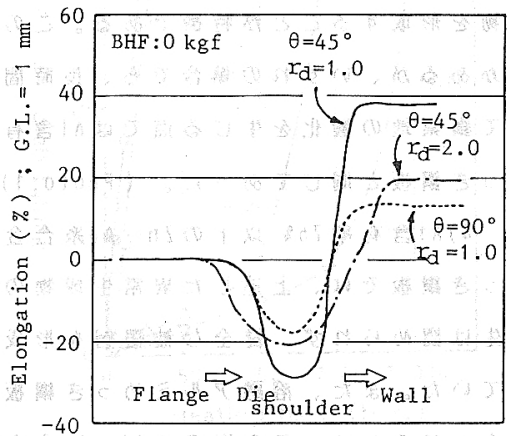

Fig. 2 Strain history in U-shaped bending with different die angle and radius of die shoulder 
（477） $5500^{\circ} \mathrm{C}$ 加熱における $\mathrm{Fe}-\mathrm{Zn}$ 金属間化合物の局部形成

\section{( Zn-AI系合金めっき鋼板の耐熱特性Ｉ）}

日新製( 制) 际神研究所 内田幸夫住谷次郎藤田充

服部保德広濑祐輔

1. 緒言

最近、種々の組成の $Z n-A I$ 系合金めつき銅板が笠品化され始めているが、本報では、Zn一AI系合金めつ

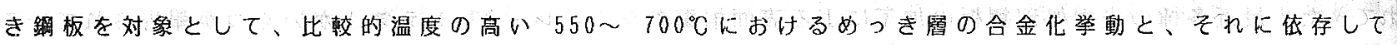
変化する耐熱特性を検討した。

\section{2. 実験方法}

板厚 $0.5 \mathrm{~mm}$ 、板稫 $300 \mathrm{~mm}$ 低炭素リムド鈎冷間圧延コイルを原板とし、無酸化炬方式の溶融めつきパイ ロットラインを用い、A|含有率 $0.18 \sim 75 \%$ の Zn-AI系合金めつき铜板を作製した。なお、Al含有率 $30 \%$ 以上のめつき浴には、合金厦の成长を抑制するため、A含有率の3\%を目整にSiを添加した。得られた供試 材は、 $550^{\circ} \mathrm{C}$ の大気中で加熱試験に供し、それぞれの酸化增量測定、被覆層の断面組織覾繁、被覆層を形 成する金属間化合物の同定、加熱中のZnの減少量测定および一部の 供試材についてはマフラ一材としとての性能を調查した。

\section{3. 実驗結果}

1) $550^{\circ} \mathrm{C}$ で加熟した時の酸化增量は、0.18\%Al材で最大となり、 めうき層中のA 含有事 0.18 から $30 \%$ までの間で念激に減少した。 そして、それ以上のAI含有率では、AI含有率の譄加に伴ない酸化增 量はゆるやかに隇少した。(Fig.1)

2)Al合有率 $13 \%$ 以下の $\mathrm{Zn}-\mathrm{AI}$ 系合金めっき鋼板では、局部的に生 成される $\mathrm{Fe}-\mathrm{Zn}$ 系金属間化合物が䤜素地酸化の起点となっていた。 これは、Al-Fe系金属間化合物の成長に伴ない溶融状態にあるめっ き層中のAl濃度が低下し、自触反応を起こすことによると考えられ る。

1)山口洋。久松敬弘：轶と鋇，63(1977)，P，1160

3) A I含有率30〜55\%のZnーAI系合金めつき銅板の場合には、連続 した $\mathrm{A} \mid-\mathrm{Fe}$ 系金属間化合物層を押し上げるように架出した異常生成 物を形成することが特徵である。この異常生成物には二種類の形熱 があるが、いずれの場合でも、長時間の加熱でこの部分を起点とし

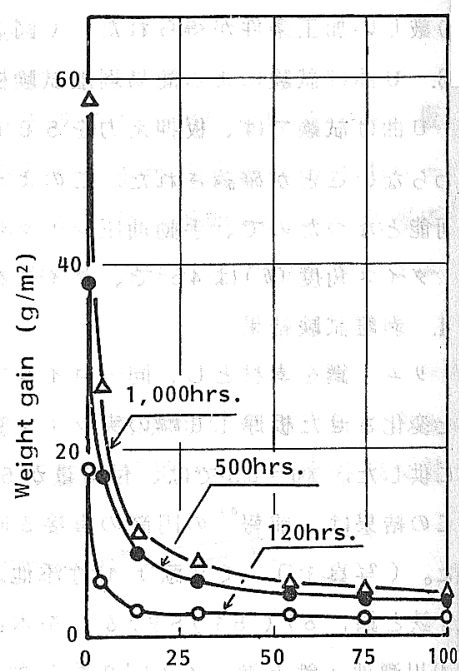

Al content of coatings $(\%)$

Fid. 1 Relation between weight gain and $\mathrm{Al}$ content of $\mathrm{Zn}-\mathrm{Al}$ coatings by oxidation at $550^{\circ} \mathrm{C}$

て鐥素地の酸化を生じる虎ではAI含有率 $13 \%$ 以下のZn-AI系合金め

つき鍋板と同じであった。(Photo１）

4)A I合有率 $75 \%$ 以上のZn-AI系合金め つき銅板では、上述した異常生成物の発

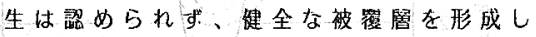
ていた。また、溶融アルミめつき錀板( タイプ）は、この溫度でAI-Fe合金化 反巵を起こさないので、健全な被復層を そのまま保持している。

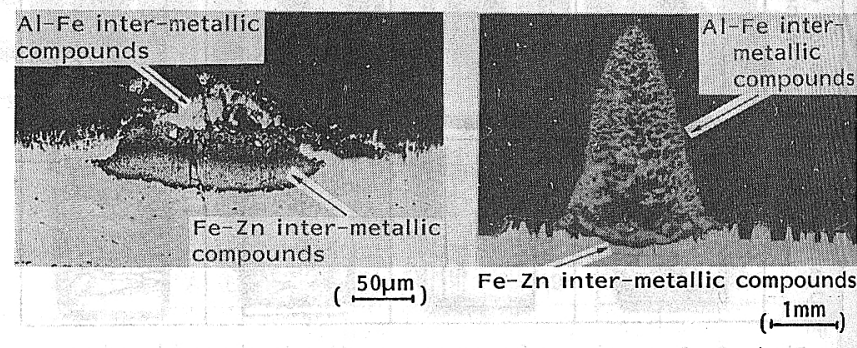

Photo. 1 Cross-sectional microstructures of anomalous corrosion products (55\% Al: $24 \mathrm{hrs}$. at $550^{\circ} \mathrm{C}$ ) 
（478） $7000^{\circ} \mathrm{C}$ 加熱における酸化增量に及ほす被覆首構造の変化

$(2 n-A)$ 系合金めつき鎆板 穴耐熟特性 II )

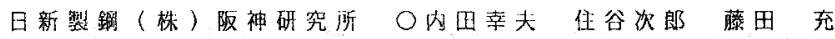

服部保镘広瀨裉輔

1.. 緒 言

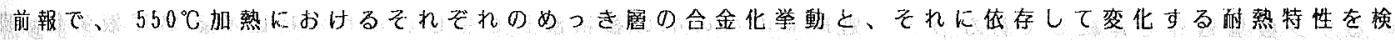
㳔し、局部的に生成される $\mathrm{Fe}-\mathrm{Zn}$ 系金属間化合物が錪素地酸化の起点となることを明らかとした。本報では

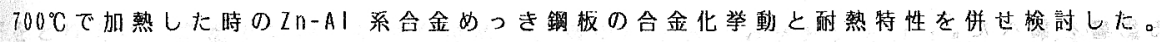

2. 実験方法

浴骶めつきパイロットラインで作製したAI含有率0.18〜75\%の Zn-Al系合金めつき鋼板を用いて $700^{\circ} \mathrm{C}$ の大気中で加熱試験を行ない、前報と闰様の各種測定に供した。

3. 実㩆結果

1)700 $\mathrm{C}$ で加熱した時の酸化增量は、 $550^{\circ} \mathrm{C}$ 加熱の場合より 著しく多くなるが、AI含有率が高くなるにしたがってその增量

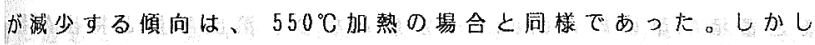
$700^{\circ} \mathrm{C}$ 加熱では、AI含有率50\%前㖟で酸化增军が極小となり、 さらにAI含有率が高くなるとその增婜も若干、多くなるという 特異現象が認められた。(F洒.1)

2)Al含有率13\%以下のめつき鍓板の酸化堌量曲線は、三段に 变化しており、後段の酸化速度は冷延鋼板の酸化速度と同じと なった。そして、第一段呚の酸化増量は、Fe中に固溶したAlの 搪散居の有無巨传存していることが推察された。(Fig，2)

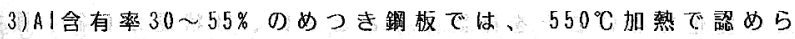
れた架出した異常生成物は讙められないが、较り加工などによ りあらかじめ加鷲前の合金層に徽小割れを生成させると、この 温度でも異常生成物を形成した。(Photo.1)

4)AI含有率 $75 \%$ 以上のめっき鎆板では、溶融アルミめっき銅 板(タイプ1)と同様、乫出した異常生成物を形成せず、連続 したAI-Fe系金属間化合物層が安定して形成されていた。

以上の結果から、AI含有事 $55 \%$ 以下の $Z n-A 1$ 系合金めっき铜 板を550〜 $700^{\circ} \mathrm{C}$ の温度で使用すると、鈎板の保護機能が著 し

く低下するのに対して、Al 合有率 $75 \%$ 以上の $2 \mathrm{n}-\mathrm{A} I$ 系 合金めつき鋼板およひ浴融 アルミめつき銓板（タイフ

1)は良好な耐熱特性を有 していることが明らかとな ot。

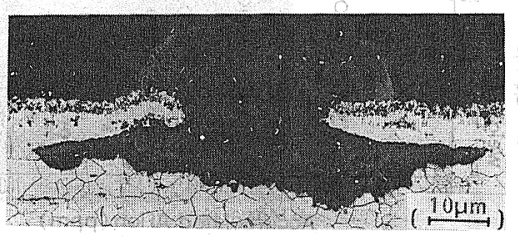

Photo. 1 Cross-sectional microstructure of anomalous corrosion product at cup wall (55\%Al: $1,000 \mathrm{hrs}$. at $700^{\circ} \mathrm{C}$ )

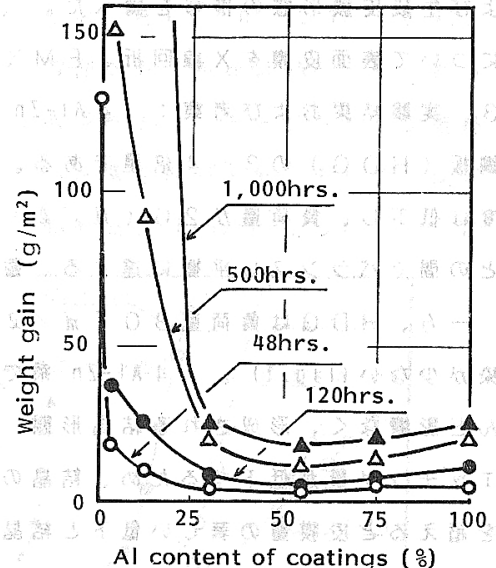

Fig. 1 Relation between weight gain and $\mathrm{Al}$ content of $\mathrm{Zn}-\mathrm{Al}$ coatings by oxidation at $700^{\circ} \mathrm{C}$

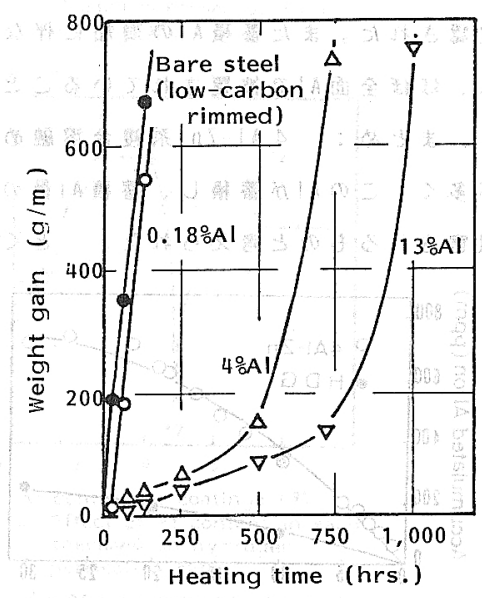

Fig. 2 Weight gain curves of $\mathrm{Zn}-\mathrm{Al}$ coated steel sheets ( $\mathrm{Al} \leqq 13 \%$ ) (heated at $700^{\circ} \mathrm{C}$ ) 
$' 84-\mathrm{S} 480$

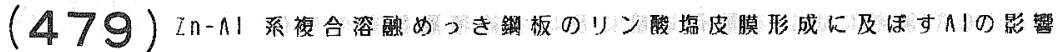

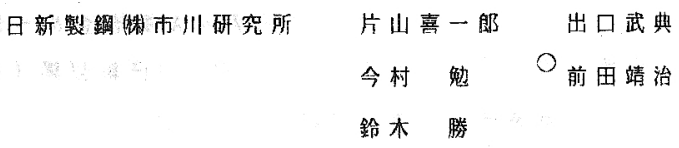

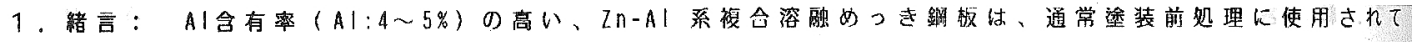

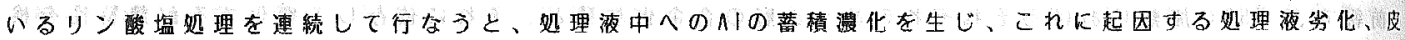

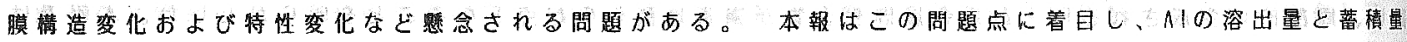
の処理特性に与える影醫を調べた。

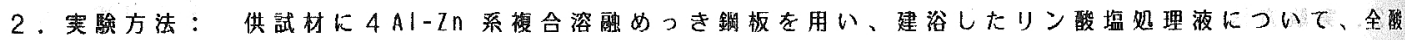

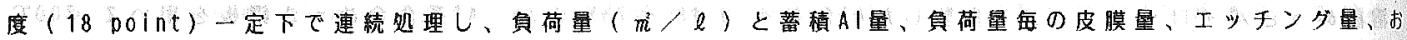
よび生成皮脱形態の推移を調べた。また蕃積したAI量の、皮膜形成反応に与える影䍌を䜕べるため処理板 について表面皮膜をX線回折、EMX、I M 、 、他の分析を行なった。

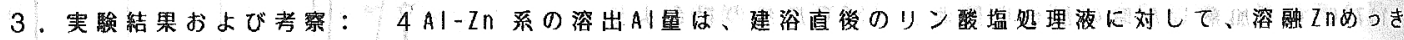

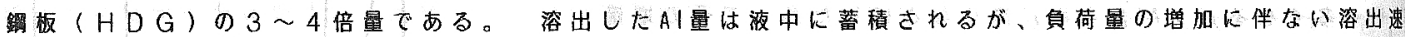

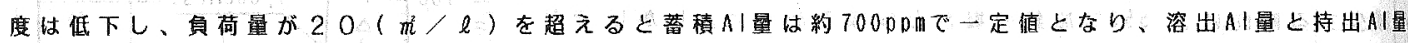
との間でバランスし平衡に達する。蓄㺓AI量の増加に伴ない、皮膜壁、エッチング量は低下の傾向にある。

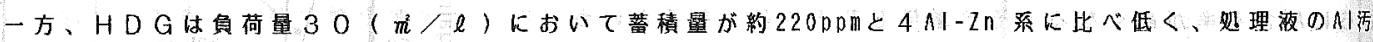

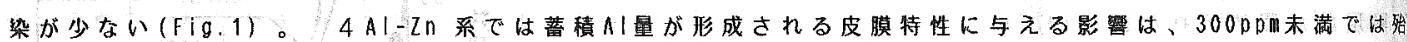

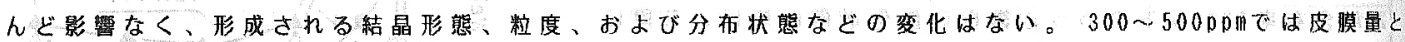
エッチング墨が低下するため、結晶の分布状態に差が生じ、䧶密性が失なわれる慎向にある。さらに50000几 を超えると皮脱鱼の著しい低下と結鼠形態そのものも、リン酸塩独自の針状晶から粒状晶に変化するなと、

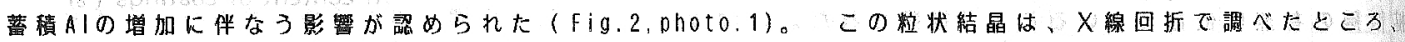

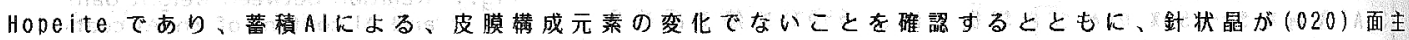
体の結晶配向を呈するのに対し、新たに(111)，(221) 面など混在する結晶配向に変化したものであることか

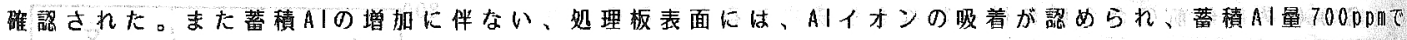
は、ほほ全面Aけで被覆されていることが確認された。

4.まとめ： $4 \mathrm{Al}-\mathrm{Zn}$ 系複合溶融めつき鋼板をりン酸塩処理すると、通常のHDGに比べて溶出するAl量

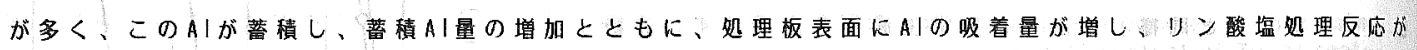
阻害されるものと考えられた。とくに500 D D mを超えるとリン酸塩皮脱形成に与える影䈏が犬きい。

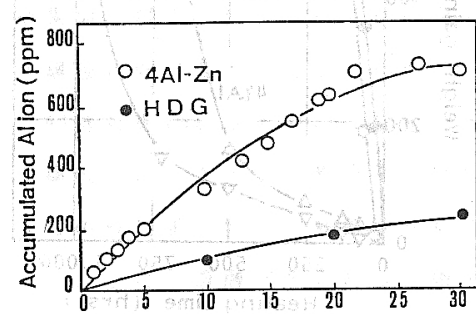

Treated surface area $\left(\mathrm{m}^{2} / \mathrm{l}\right)$

Fig.1. Relationship between the amount of treated surface area and accumulated A! ion.

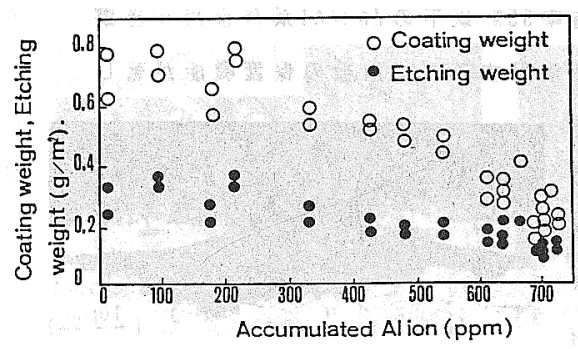

Fig.2. Relationship between accumulated Al ion and zinc-phosphate coating weight, etching weight.

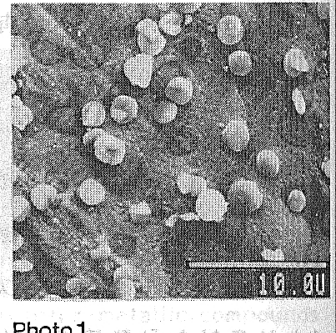

Photo 1 SEM image of $4 \mathrm{Al}-\mathrm{Zn}$ alloy layer phosphated in a zinc-phosphate bath containing $700 \mathrm{ppm}$. Al ion. 
1. 緒 言

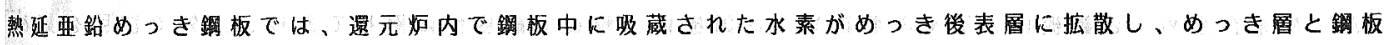
との界面でブリスターを発生することが知られている。本報では、ブスタ一発生に及ほすめっき層侧の因 子をとり上げ、常温でのZnーAl系合金めっき層中の水素透過挙動に及ぼすめっき層組成の影犗について調查 した結果を報告する。

2. 実跧方法

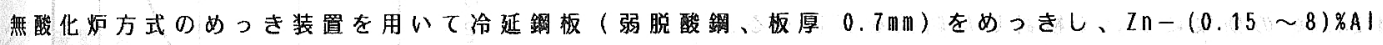

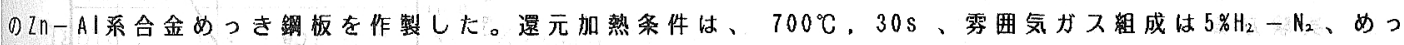
き後の掵却条件は放冷〜水冷とした。めっき層中の水素の透過挙動は、水素電解チャーチーグリセリン置換 法により調查した。すなわち、片側のめつき層を研瘏、除去し、その面から水素を電解チャーチして、反対

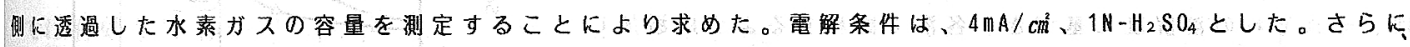
水素吸蔵の指標の一つとして、めっき層中のZnおよびA|の結 晶格子歪みを入線回折法により調查した。

\section{3 . 実験結果}

1)いずれのめつき層鉏成についても、原板およびめつき層 中での水素吸蔵過程に対応する初期状態と水素透過過程に対 店する定常状態にわけられた。(Fig.1)

2)定常状態における水素透過速度は、めつき層中のA）濃度に 依存して変化し、(2〜8)\%AIの籁囲では $5 \%$ で極小となった。 (Fig, 2)

3)X楾回折法によるめつき層中AIと Znの結晶格子歪みの测定 结果およびめつき層のミクロ組織と水素ガス放出サイトの関 䋆(Photo１）をあわせ考えると、水素の透過举動はめっき㞸 のミク口組織に依存しており、初晶 $Z n$ あるいは初晶 $\mathrm{Al}$ と $Z n-$ AI共晶部との境界を優先的に透過していると推定できた。

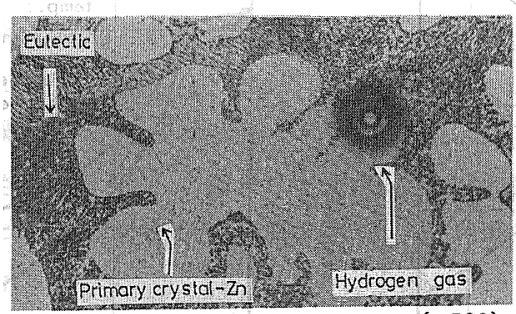

Photo. 1 Initial of portion where hydrogen diffused through the layer of 4 : $\mathrm{AI}-\mathrm{Zn}$ coating

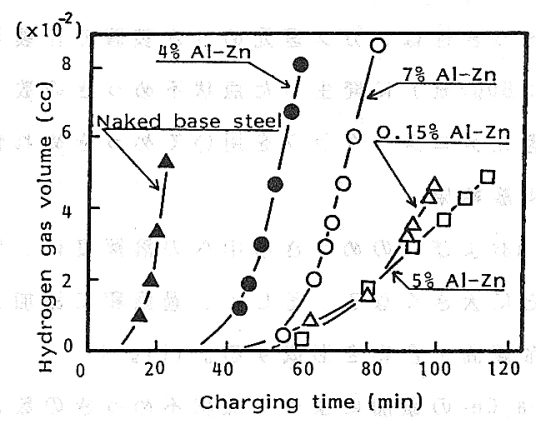

Fig $t$ Bydrogen permeation behavior of each specimen at room

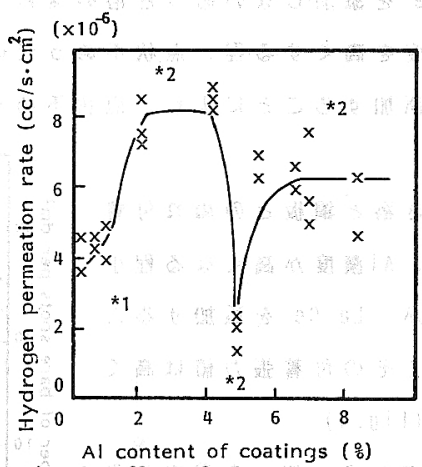

Fig. 2 Effect of Al content in each specimen on hydrogen permeation rate

*1 All of hydrogen gas evolved through the cracks of blisters

*2 Most of hydrogen gas permeated through the phase boundaries 
1. 粕言

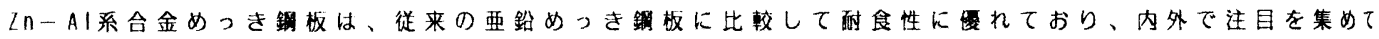
いるが、その製造に当っては、点状不めつきが発生し易いという問題がある。これについては、ミッシュ・ メタルの添加によってめつき性が向上するといわれているが、 その奻果について、定量的に検討された事例はない。本報では 此較的 $\mathrm{A} \mid$ 濃度の低い $Z n-A \mid$ 系合金浴での銅板のめつき性に及ほ すLa，Ceの效果について䄼封した結果を報告する。

\section{2. 実涘方法}

Al濃度 $0.16 \sim 26.0 \%$ の $2 n-A \mid$ 浴KLa，Ceを複合添加してめ っき浴とした。なお、めつき浴温は、点 $+50^{\circ} \mathrm{C}$ とし、La，Ce は、それぞれの溶解度に基づき、各浴で飽和するように添加し た。めつき性は、ガス退元めつき装置で作製しためつき材（付 着量： $60 \mathrm{~g} / \mathrm{m}$ )に発生した点状不めつきの数で評価した。また ガス逗元メニスコグラフを用いてめつきぬれ性を测定した。

\section{3. 実䀫結果}

1)しaおよびCeのめっき浴中への溶解度は、Al浱度が高くなる とともに大きくなる。そして、過飽和に添加されたLa，Ceは L n との金属間化合物を形成する。(十ｉ．１)

2) La，Ceの添加によって点状不めつきの数は減少するが、そ の傾向はA 浪度が高い程顆著となる。(Fig. 2)

3) La，Ce を添加しないめつき浴の場合、めつき前の鍽板の镸 元焼鈍温度を高くする程、点状不めつきの個数は增加するが、 La，Ceを添加することにより、点状不めつきは大幅に隇少した。 (Fig. 3)

4)めつき浴と粄とのぬれ付着 張力值は、AI浱度が高くなる程小 さくなるが、La，Ce を添加するこ とによってその付着張力値は高く なった。(Fig. 4)

以上のこととく、めっき浴中への La, Ceの微量添加は、めつき錆板 の点状不めつきの低減に奻果があ ることが明らかとなった。

Fig. 3 Effect of La, Ce addition and

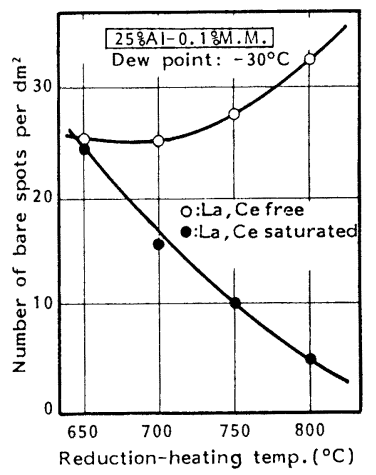

1) 特開昭 $56-501400$

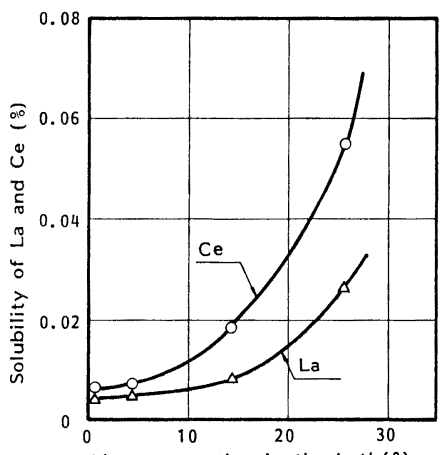

Al concentration in the bath( 8 )

Fig. $1 \mathrm{Al}$ concentration v.s. solubility of $\mathrm{La}$ and $\mathrm{Ce}$

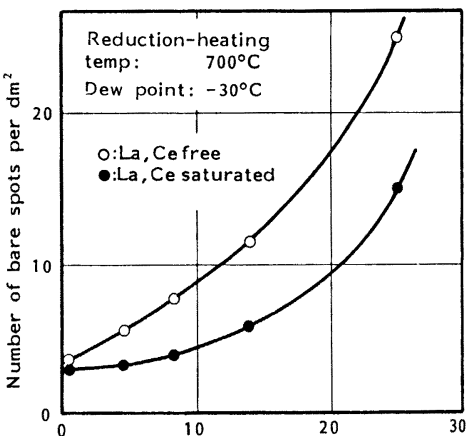

Al concentration in the bath $\left(\frac{q}{b}\right)$

Fig. 2 Effect of $\mathrm{La}, \mathrm{Ce}$ addition and $\mathrm{Al}$ content on bare spots

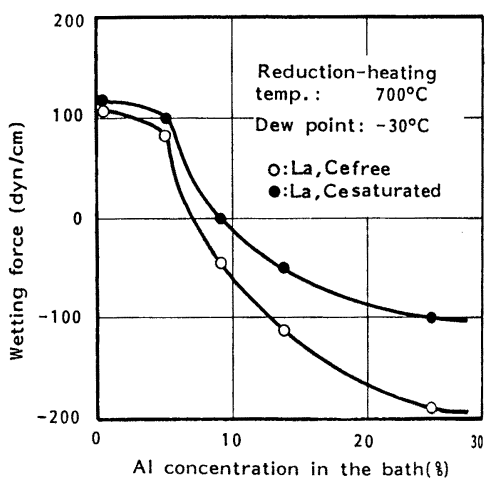

Fig. 4 Effect of La, Ce additon on wettablity 


\section{（482）高强度油井管の破壊勒性}

' $84-$ S 483

日本鋼管株技術研究所島田透稲積透

石沢嘉一 谷村昌幸

\section{1. 舶 言}

前回, ${ }^{1)}$ 冷間加工型のオーステナイト系油井管から全管厚のコンパクトテンション (CT) 試験片を採取し A S T M E 399 ，E８13に従って破壊勒性試験を行った結果を報告した。今回, 数種類の材質の油井 管に対して試験を行ない, 各種油井管の破壊勒性および破壊靭性とシャルピ一試験結果との相関につい て検討したのでその結果を報告する。

\section{2. 実験方法}

Table 1 に示す材質, 強度水準の各種油井管から, 全管 厚のC T試験片を採取し，ASTME３９９，E８１3亿従 ってKc，J IC值を求めた。前報で述べたように，E３９９法 では有効なKc值が得られないものについては，E８１3法に よる J I 值を換算してKc值を求めた。また同一のパイプか ら管周方向の J I S 4号シャルピー試験片を採取し、シャル ピー試験を行った。

\section{3. 実験結果}

(1)E 399 法では, $\mathrm{P}_{\max } / \mathrm{P}_{\mathrm{Q}}$ の值が 1.2 以下になってい る場合に，E８１3 法ではすべての場合に実際の破壊開 始に対応する有効な破壊鞄性值が得られた。

(2) Fig. 1に今回試験した油井管の Kc 值と降伏応力の関係 を示す。同一強度水準で比較した場合，Cr-Mo型の低 合金系油井管が，冷間加工型のオーステナイト系油井 管等と比較して高い破壊勒性を示した。

(3)破壊力学に基いた計算によると, これらの油井管の靫 性は，それぞれの強度水準の油井管として満足すべき ものである。

(4)今回試験した油井管の破壊勒性とシャルピー試験の吸 収エネルギーの間には，Fig.2に示すようにかなり良 い相関関係が認められた。この相関関倸は材質の相違 に影響されない。この結果, 油井管の破壊勒性值は, シャルピー試験の結果から推定することが可能である ことが示された。

1）島田他, 鉄と鋼, $69(1983), \mathrm{S} 1399$

Table. 1 Materials and strength levels of tested $\mathrm{OCTG}$

\begin{tabular}{|ll|}
\hline C-Mn steel & $110 \mathrm{ksi}$ grade \\
Low alloy $(\mathrm{Cr}$ Mo)steel & $90-150 \mathrm{ksi}$ grade \\
$9 \mathrm{Cr}-1 \mathrm{Mo}$ steel & $80 \mathrm{ksi}$ grade \\
$\begin{array}{l}\text { Austenitic alloy } \\
\text { (cold reduced) }\end{array}$ & $110-140 \mathrm{ksi}$ grade \\
\hline
\end{tabular}

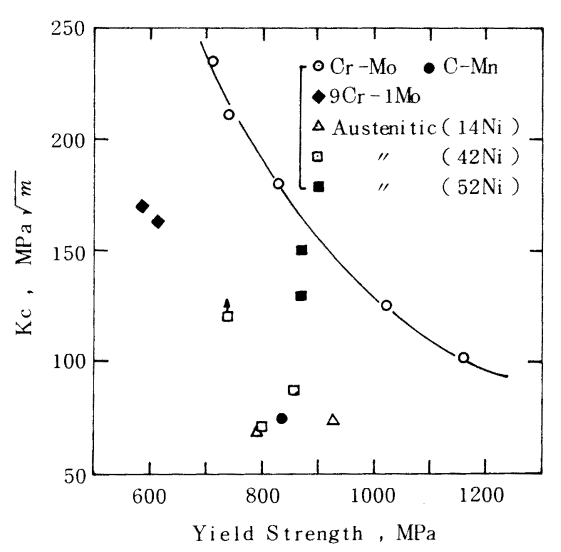

Fig.1 Kc values of tested OCTG.

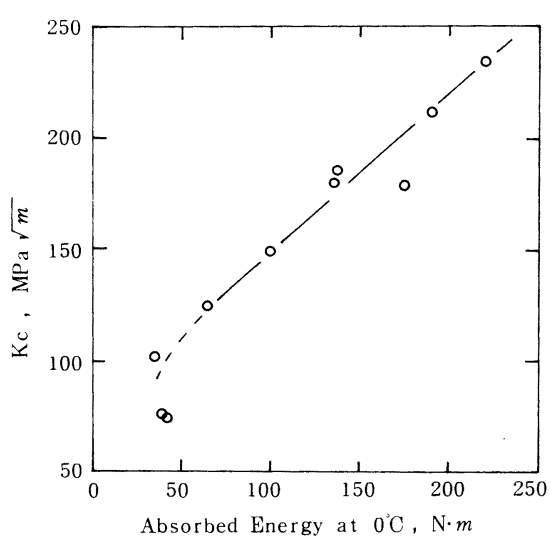

Fig.2 Relationship between the fracture toughness and Charpy data. 


\section{（483）油井管のコラプス強度に及ぼす応カーひずみ曲線の影響}

（油井管のコラプス強度の有限要素法解析 第 3 報）

住友金属工業㑣) 中央技術研究所 時政勝行, ${ }^{\circ}$ 田中健一

\section{1. 緒 言}

油井管のコラプス強度に及ぼす残留応力と管材降伏特性の影響は, 実験的手法による解明が難しく, 筆者らは，F E M解析による検討を進めてきた。前報では完全弾塑性材料の管の塑性コラプス強度に及 ぼす残留忘力の影響を定量的に明らかにした。ことでは, 残留忘力の無い管の塑性コラプス強度に及ぼ す管材料の応力〜ひずみ曲線（ S - S 曲線）の影響について報告する。

\section{2. 解析方法}

2 - 1. $\mathrm{S}-\mathrm{S}$ 曲線形状

Fig. 1 亿示す $2 つ 0 S-S$ 曲線形状 ( 線形硬化則に 従う場合と指数硬化則飞従う場合）について、コラプ ス強度に及ぼす硬化係数 $\mathrm{H} お$ よび硬化指数 $\mathrm{n}$ の影響を 求めた。

$2-2$. 計算結果の一般化

硬化係数 $\mathrm{H}$ および硬化指数 $\mathrm{n}$ のコラプス強度に及ほ

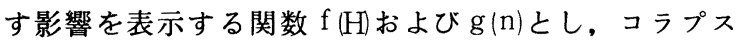
強度 Pcr が
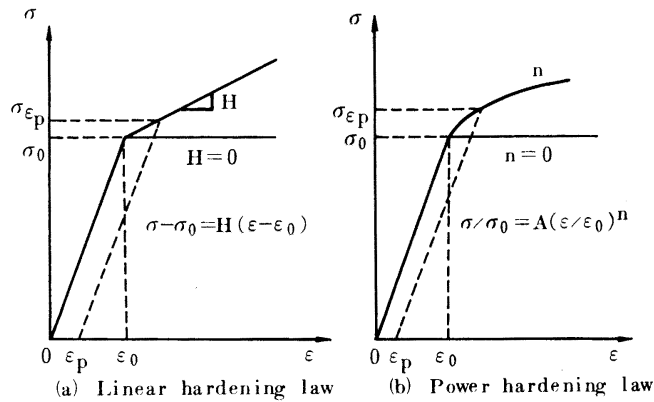

Fig.1 Stress-strain curves used for the FEM analysis

$$
\mathrm{Pcr}=2 \sigma_{0} \frac{\mathrm{D} / \mathrm{t}-1}{\mathrm{D} / \mathrm{t})^{2}} \mathrm{f}(\mathrm{H}) \text { または } \mathrm{Pcr}=2 \sigma_{0} \frac{\mathrm{D} / \mathrm{t}-1}{(\mathrm{D} / \mathrm{t})^{2}} \mathrm{~g}(\mathrm{n})
$$

で表示できると仮定して， $\mathrm{f}(\mathrm{H}), \mathrm{g}(\mathrm{n})$ を求めた（ただし， $\mathrm{H}$ $=0, \mathrm{n}=0$ の完全弾塑性体の場合， $\mathrm{f}(0)=\mathrm{g}(0)=1)$ 。式(1) を $\boldsymbol{\sigma}_{\varepsilon \mathrm{p}}(\varepsilon \mathrm{p}$ オフセット耐力 )を基準として書き直すと次式が 得られる。

$$
\begin{aligned}
& \frac{\mathrm{Pcr}}{\operatorname{Pcr} H=0}=\left[1-\frac{\mathrm{H} \varepsilon_{\mathrm{p}}}{(1-\mathrm{HE}) \boldsymbol{\sigma}_{\varepsilon \mathrm{p}}}\right] \mathrm{f}(\mathrm{H}) \\
& \frac{\mathrm{Pcr}}{\mathrm{Pcr}_{\mathrm{n}=0}}=\left[\frac{\sigma_{\varepsilon \mathrm{p}}}{\left(\mathrm{E} \varepsilon_{\mathrm{p}}+\sigma_{\varepsilon \mathrm{p}}\right)^{\mathrm{n}}}\right]^{\frac{1}{1-\mathrm{n}}} \frac{\mathrm{g}(\mathrm{n})}{\boldsymbol{\sigma}_{\varepsilon \mathrm{p}}}
\end{aligned}
$$
ただし

$$
\operatorname{Pcr}_{\mathrm{H}=0}=\operatorname{Pcr}{ }_{\mathrm{n}=0}=2 \sigma_{\varepsilon} \mathrm{p} \frac{\mathrm{D} / \mathrm{t}-1}{(\mathrm{D} / \mathrm{t})^{2}}
$$

式(2)(3)は， $\mathrm{H}$ あるいは $\mathrm{n}$ の影響を無視し $\sigma_{\varepsilon \mathrm{p}}$ を管材の降伏強度とし て用いて塑性コラプス強度を(4)式で推定したときの差異を示す。

\section{3. 結 果}

(1) $\sigma_{\varepsilon \mathrm{p}}$ として， $0.2 \%$ 耐力 $\sigma_{0.2}$ を用いた場合，硬化係数あるいは硬 化指数が大なるほど塑性コラプス強度は式(4)で求まる值よりも低下 する(Fig.2)。

(2) $\sigma_{\varepsilon \mathrm{p}}$ として、 $\sigma_{0.04}$ を用いれば $\mathrm{S}-\mathrm{S}$ 曲線形状に拘わらずコラプ 又強度は式(4)で近似的に求め得る(Fig。2,Fig.3)。

参考文献 (1) 時政, 田中：鉄と鋼, Vol.69No.13(1983), s 1398

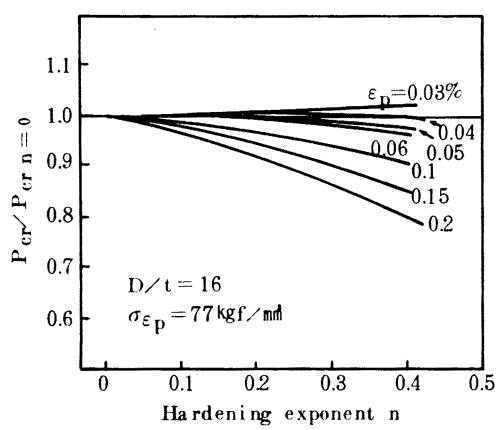

Fig.2 The effect of hardening exponent $n$ on the collapse strength

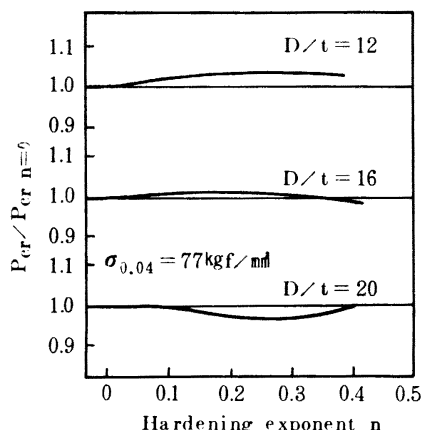

Fig.3 The effect of $\mathrm{D} / \mathrm{t}$ on the estimation of collapse strength with eq.(4) and $\sigma_{0.04}$ 


\title{
(484) 低温靭性に優れた高強度構造物用継目無鋼管の直接焼入れによる製造
}

\author{
川崎製鉄秼技術研究所 ○岩崎義光、小林邦彦 \\ 上野雄夫 \\ 知多製造所 小山康衛
}

1. 緒 言 : 最近の海洋石油開発は深海域や寒冷地にも及び、海洋リグやラインパイプに強䩓性・高 強度継目無鋼管が切望されている。直接焼入れ $(\mathrm{DQ})$ は再加熱焼入れ $(\mathrm{NQ}) に$ に比べ、焼戻し後高強度が期待 できる。HT 60〜80、API 5LX60〜U80級継目無鋼管は、低温鞀性の観点から N Qにより製造されること が多い。ここでは、DQにより製造することを意図した検討結果と円周溶接継手の特性を報告する。

2. 実験方法：供試材は低炭素低合金鋼で (Table 1)、5ト真空溶解炬で溶製後丸ビレットに鍛造し、プ ラグミル方式で外径 7”、肉厚 1"に造管後、直接焼入れ焼戻し処理を施した。焼入れは浸漬型内外面軸流 焼入れ方式 ${ }^{1)}$ である。さらに、低水素系溶接棒を用い、入熱 $17 \mathrm{~kJ} / \mathrm{cm}$ の手溶接にて円周溶接継手を作成し た。母材および継手の確性は、引張試験・シャルピー衝撃試験を主体とした。

3. 実験結果: (1)DQ後 $620^{\circ} \mathrm{C} ・ 15$ min焼戻しにより、HT60〜80、X60〜U 80 相当の強度が得られた (Fig. 1 )。 (2)衝撃勒性は強度の上昇とともに劣化する傾向にあるが (Fig.1) $\mathrm{vE-50} \geqq 18 \mathrm{~kg} ・ \mathrm{~m}$ が確保された。特に、 $B$ 処理鋼の鞄性が良好であった。

(3)継手性能でも、母材と同等の強度が得られた。 L $/ \mathrm{P}$ 用材 （L1〜L4）は $-30^{\circ} \mathrm{C} て ゙ 、 R I G$ 用材は $-50^{\circ} \mathrm{C} て ゙$ 勒性を調べた結果、 $4.8 \mathrm{~kg} \cdot \mathrm{m}$ 以上の吸収エネルギーが確保された (Fig.2)。

(4) B 処理鋼で優れた低温鞄性を実現するには、焼入れ後残 留固溶 $\mathrm{Ti}$ 量 $\triangle \mathrm{Ti}(\equiv \mathrm{Ti}-3.42 \mathrm{~N})$ を、 $-0.007 \% \leqq \triangle \mathrm{Ti} \leqq 0.002 \%$ と なるよう、成分設計するのが望ましい(Fig. 3)。

以上、高強度継目無鋼管が DQから製造可能となった。

Table 1 Chemical compositions(wt \%)

\begin{tabular}{|c|c|c|c|c|c|c|c|c|c|c|c|}
\hline Heat & Alloy & C $\mathrm{Si}$ & $\mathrm{Mn}$ & $\mathrm{Ni}$ & $\mathrm{Cr}$ & Mo & $\mathrm{V}$ & $\mathrm{Ti}$ & $\mathrm{Al}$ & & $\underset{p p m}{N}$ \\
\hline $\mathrm{L}_{1}$ & TiB & 0.090 .25 & 1.29 & - & -- & - & - & 0.009 & 0.040 & 10 & 28 \\
\hline $\mathrm{L} 2$ & MoTiB & 0.090 .25 & 1.28 & - & - & 0.14 & - & 0.009 & 0.042 & 9 & 28 \\
\hline L3 & $\mathrm{CrMoV}$ & $0.10 \quad 0.26$ & 1.28 & - & 0.11 & 0.140 & 0.038 & - & 0.049 & - & 31 \\
\hline $\mathrm{L} 4$ & CrMoVTiB & 0.100 .26 & 1.28 & - & 0.11 & 0.130 & 0.039 & 0.009 & 0.044 & 8 & 29 \\
\hline R1 & NiCrMoVTiB-I & 0.090 .26 & 1.25 & 0.60 & 0.07 & 0.130 & 0.030 & 0.009 & 0.065 & 11 & 45 \\
\hline R2 & NiCrMoVTiB- $\square$ & 0.100 .26 & 0.92 & 1.01 & 0.61 & 0.380 & 0.034 & 0.009 & 0.050 & 11 & 38 \\
\hline
\end{tabular}

i) 滝谷他：鉄と鋼、67,'81-1301.

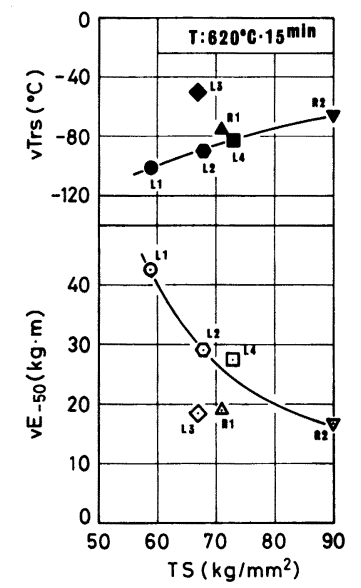

Fig. 1 Relation of $v T r s$ and $v E_{-50}$ in the longitudinal direction with TS after direct quenching and tempering.

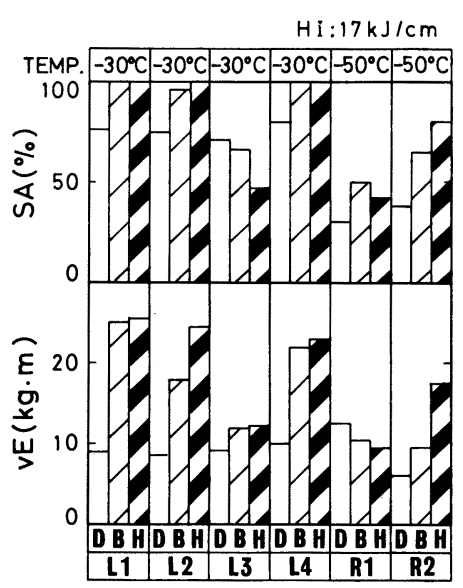

Fig. 2 Impact test results of welded joint (D:Deposited metal, B:Bond, $\mathrm{H}: \mathrm{HAZ}, \mathrm{HI}:$ Heat Input).

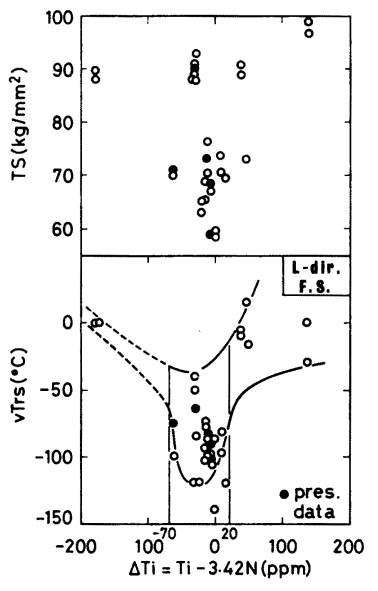

Fig.3 Optimum $\triangle T i$ for realizing high toughess after direct quenching and tempering(F.S.:Full Size). 
' $84-\mathrm{S} 486$

(485) 機械的性質・金相組織に及ぼす焼入れ前組織の影響

低合金鋼の焼入れ処理に伴なう特性変化 (1)

住友金属工業(侏) 中央技術研究所 大谷泰夫, ${ }^{\circ}$ 津村輝隆

\section{1. 緒 言}

鋼材の高張力化，高勒化に対処するために，オーステナイト粒径や変態生成物の組織を微細化するて とが試みられており，高周波誘導加熱等による急速加熱処理はその一例である。しかし乍ら急速加熱処 理では細粒化は達成されても，特に合金元素を多く含む成分系で，鋼が均質化されにくいという欠点が ある。一方高靱細粒化元素として知られているNiを多量添加した場合には，Ac $\mathrm{c}_{1}$ 点が低くなるので高い 焼戻し温度を採用できないしいう問題がある。さて焼入れ特性に関し焼入れ前処理としての加工の影響 については明らかにされている事む多いが，焼入れ前の金相組織的観点からの報告は少ない。そてで本 報では鋼の焼入れ前組織を異なえて，従来加熱法により焼入れ焼戻し処理して特性比較を行った。

2. 実験方法

表 1 亿示す 2 鋼種を熱間压延後，(a)粗大ベイナイト （压延材），(b)微細ベイナ1ト(焼準材)，(c)マルテ ンサイト（焼入れ材）を夫々前組織にして電気炉加熱 によって焼入れ焼戻し処理し,引張り・衝撃性能の調 査とミクロ観察を行った。

\section{3. 実験結果}

(1) 焼入れ前組織の機械的性質に及ぼす影響は鋼 Aについては観察されなか つたが。鋼Bについては図 1 亿示す様な大きな差が認められた。

(2) 鋼 Aでは前組織のオーステナイト粒径に及ぼす差が小さいのに対して, 鋼 Bでは(a)，(b)，(c)の順にオーステナイト粒が細かくなる(写真 1)）。図 1 の 完全焼入れ組織に打ける強度・鞄性の差は,とのオーステナイト粒径に基因す るものである。

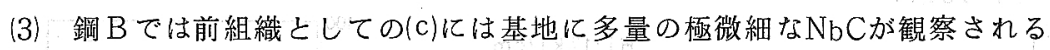
(写真 2 )。一方(b)ではそれが少なく，(a)ではNbCは粗大である。微小NbCに よってマルテンサイトやべイナイトの再結晶が抑制されて, 鋼 $\mathrm{B} て ゙ は ~ A c_{1}$ 点以 上での変態・粒成長に差が生じたものと考えられる。

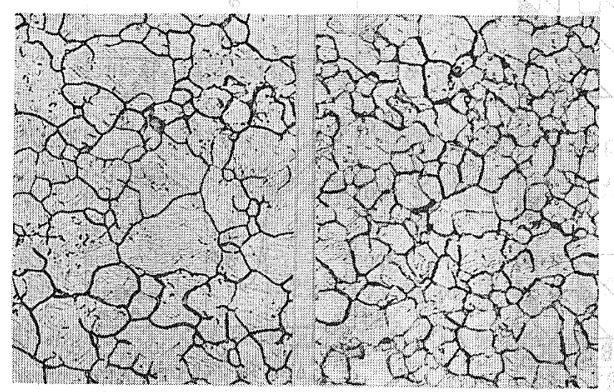

(a) $\# 8$
Photo. 1. Comparison of austenite grains in steel $\mathrm{B}$ after quenching from $920^{\circ} \mathrm{C}$.

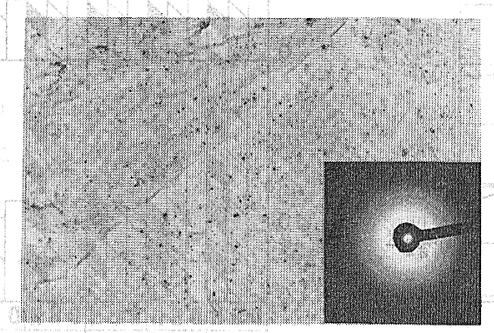

Photo. 2. Fine NbC observed in steel $\mathrm{B}$ after quenching from $920^{\circ} \mathrm{C} .(\times 20000)$
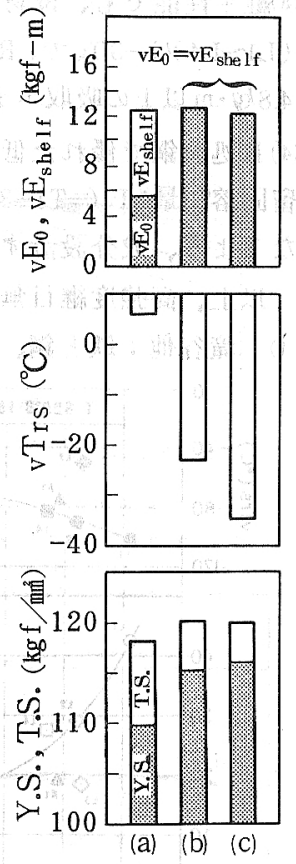

Fig. 1. Effect of initial microstructures on mechanical properties of steel $B$. $\left(920^{\circ} \mathrm{C} \cdot \mathrm{Q}+520^{\circ} \mathrm{C} \cdot \mathrm{T}\right)$ 


\section{（486） Ti-B 鋼の材質特性に及ぼす合金成分と加速冷却の影響 \\ （新厚板製造法による Ti-B系U $0 \mathrm{E}$ 鋼管の開発一第口報）}

川崎製鉄（株）技術研究所 $○$ 天野虔一波戸村太根生

\section{志賀千晃}

1. 緒言: 低 $\mathrm{C}-\mathrm{Nb}-\mathrm{V}$ 鋼において圧延後の加速冷却や, Mo, Mn, Ni, Cuの増量により, 適切な制御 殴延条件のもとでは勒性を損なうととなく強度を上昇させ得ることを報告した ${ }^{12)}{ }^{2)}$ 。最近, Ti - B 系低 Ceq のU O E 鋼管が開発されているが, てれらの鋼に対する合金成分の影響や, 圧延後の加速冷却の効 果は明らかでない。本報では,変態挙動に影響の大きいTi, B , N , A $\ell$ 量 及び加速冷却条件を変えて材質を検討した。

2. 実験方法：供試鋼は 1) 小型真空溶解炉で溶製した成分系が $0.03 /$ $0.08 \mathrm{C}-1.4 / 1.8 \mathrm{Mn}-0 / 0.05 \mathrm{Nb}-0 / 0.03 \mathrm{Ti}-0 / 0.002 \mathrm{~B}-0.02 / 0.08 \mathrm{~A} \ell$ (一部に $02 \mathrm{Cu}, 02 \mathrm{Ni}, 0.05 \mathrm{~V}$ を添加したものも含む) の鋼と，2)転灯溶製の 0.04 C $-1.5 \mathrm{Mn}-0.04 \mathrm{Nb}-\mathrm{Ti}-\mathrm{B}-\mathrm{V}$ 鋼, であり, C, Ti, B, N, A eの効果 を調査した。1)の鋼は $1150^{\circ} \mathrm{C}$ 加熱後 $730^{\circ} \mathrm{C} て ゙$ 仕上げて 16 mの板とし, 強 度と鞄性およびミクロ組織と変態挙動を調査し，2）の鋼はスラブ加熱 温度, 圧延条件および加速冷却条件を詳細に調べた。

3. 実験結果：図 1 は B 量 ( Ti : $0.03 \%, \mathrm{~N}: 0.004 \%$ )の影響を示す。 B量の増加により第 2 相（べイナイトと少量のマルテンサイト）体積率 加增加し，その結果 T S は增加するが, 鞄性はやや劣化する。乙れは第 2 相体積率の増加に伴ってフェライト粒径が細粒化しないためである。Mo, $\mathrm{Mn}, \mathrm{Ni}, \mathrm{Cu}$ の増加や压延後の加速冷却による第 2 相体積率の増加之同 時にフェライトが微細化する挙動とは異なる。N量の減少, $\mathrm{A} \ell$ 量の増加によっても同 様の結果を得た。一方, $\mathrm{Ti}-\mathrm{B}$ 鋼の $\mathrm{Ar}_{3}$ 点はボロンの効果により, 図 2

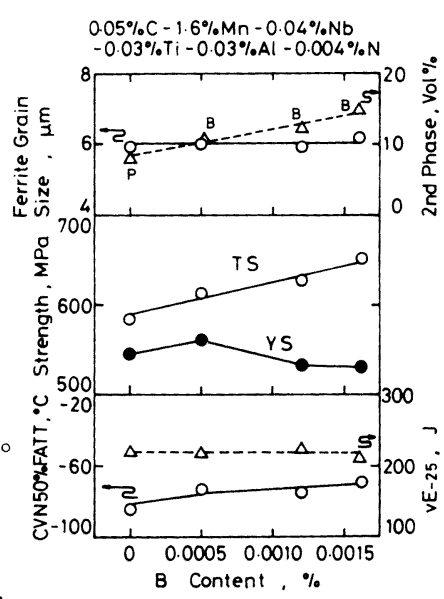

Fig. 1 Effect of boron content on mechanical properties of low C-Ti-B steel に示すように低下する。 $\mathrm{Ti}-\mathrm{B}$ 鋼の $\mathrm{Ar}_{3}$ 点は, 従来鋼の $\mathrm{Ar}_{3}$ 点 $\left(\mathrm{Ar}_{3}{ }^{*}\right)$ を用いて推定可能であり, $\mathrm{Ar}_{3}=2.01 \mathrm{Ar}_{3}{ }^{*}-800\left({ }^{\circ} \mathrm{C}\right)$ となる。ただし $\mathrm{Ar}_{3}^{*}=910-273 \mathrm{C}$ $-74 \mathrm{Mn}-57 \mathrm{Ni}-16 \mathrm{Cr}-9 \mathrm{Mo}-5 \mathrm{Cu}$ $\left({ }^{\circ} \mathrm{C}\right)$ 。

一方, 制御压延後の加速冷却に より, 空冷の場合に比べて高張 力化が可能であり勒性劣化も少 ない（図 3 ）。 $\mathrm{T} i-\mathrm{B}$ 鍴は冷却 停止温度が高くても高強度化が 可能である。

参考文献

1)志賀ら：鉄と鋼 67 (1981) S637, 2)天野ら：同上67 (1981) S1210，3)志賀ら：同上 68 (1982) A227

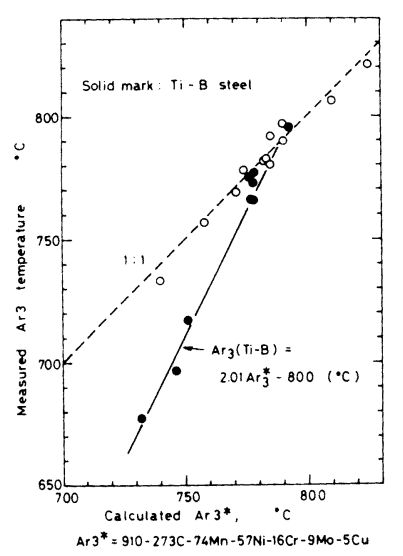

Fig. 2 Comparison of $\mathrm{Ar}_{3}$ temp. between $\mathrm{T} i-\mathrm{B}$ steel and boron free steel

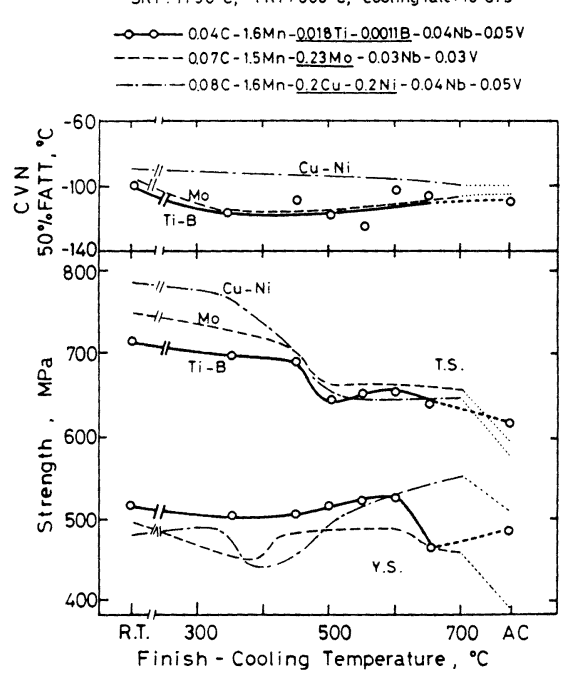

Fig. 3 Effect of finish-cooling temp. on mechanical properties of $\mathrm{Ti}-\mathrm{B}$, $\mathrm{Cu}-\mathrm{Ni}$ and Mo steels 
（487） ラインパイプの円周溶接性評価

（新厚板製造法による $\mathrm{Ti}-\mathrm{B}$ 系 U O E 鋼管の開発一第 2 報）

川崎製鉄技術研究所

○松山隼也西山昇 志賀干晃 波戸村太根生

千葉製鉄所 関沢信中川一郎

\section{1. 緒 言}

$\mathrm{T} i-\mathrm{B}$ 鋼では少量の B 添加で，勒性を阻害するてとなく鋼板の有効な強度上昇が得られるため，低炭 素当量化による溶接性の向上が期待できる。一方，BによるH A Z 硬化性を正しく予測しないと，小入 熱条件の円周溶接等では, 見掛上の 炭素当量低下にもかかわらず，却っ て溶接性の低下することがある。本 報では, (a)新しいTi-B 鋼 H A Z 硬 化性推定式と，乙れに基づき，(b)加 速冷却法（MA C S ) によって開発 した実質的に低炭素当量である $\mathrm{Ti}-$ B 系UOE 鋼管の円周溶接性検討結 果について述べる。

\section{2. 円周溶接 HAZ C硬化性評価}

ラインパイプの円周溶接における H A Z 硬度を厳しく評価するために， 最も低入熱レベル $(5.5 \sim 5.6 \mathrm{~K} \mathrm{~J} / \mathrm{cm})$ で I I W 式最高硬さ試験を行った(Fig.1, Fig. 2 )。(供試鋼板 : 板厚 $=14 \sim 32$ $\mathrm{mm}, \mathrm{C}=0.04 \sim 0.15 \%, \mathrm{Ti}=0 \sim 0.03$ $\%, \mathrm{~B}=0 \sim 0.0022 \%, \mathrm{~N}=0.0014 \sim$ $0.0075 \%)$

CE（I I W）に対し, Рс $\mathrm{M}$ は 十分な精度で H A Z 硬度を評価しう るが，いずれも $\mathrm{T} i-\mathrm{B}$ 䤱の評価に精 度が不十分である。(Hv10)maxと B 量 の詳細な関係(Fig.3)から，Bパラメ 一夕 $\left(\sqrt{\mathrm{B}-3 / 10^{4}}\right)$ を含む Carbon

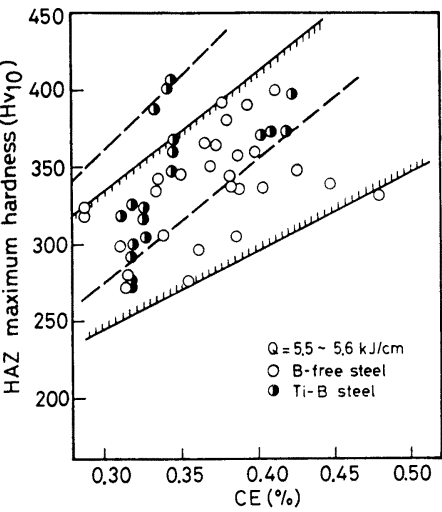

Fig. 1 CE vs. (Hv10) max

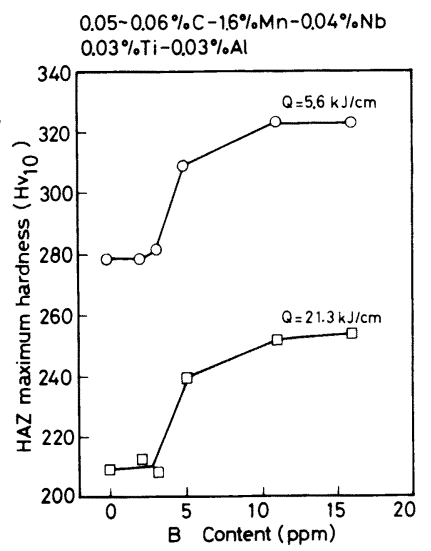

Fig. 3 Effects of B content on $\left(\mathrm{Hv}_{10} \mathrm{O}\right) \max$

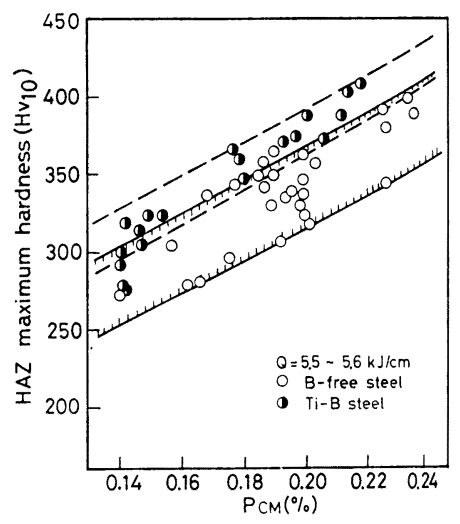

Fig.2 PсM vs. (Hvı) $\max$

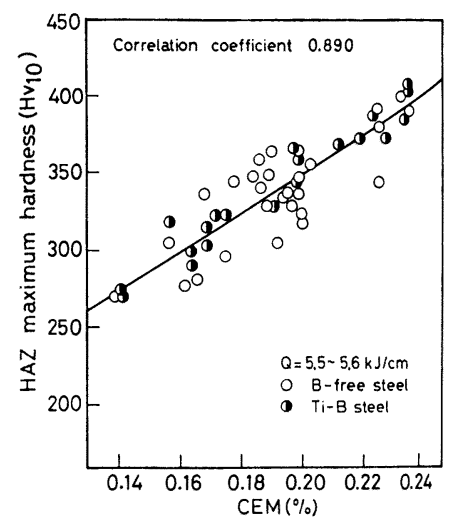

Fig. 4 CEM vs. (Hv10) max Equivalent Modif ied を提案した。

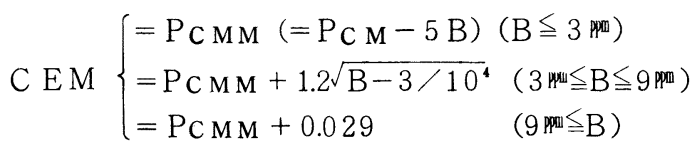

\section{MACSによるTi-B系UOE 鋼管の円周溶接性}

C E M と (Hv10)maxに十分艮い相関があり(Fig.4), C E M 概念 に基づいてMAC S 法による低炭素当量 $\mathrm{Ti}-\mathrm{B}$ 系U O E 鋼管を開

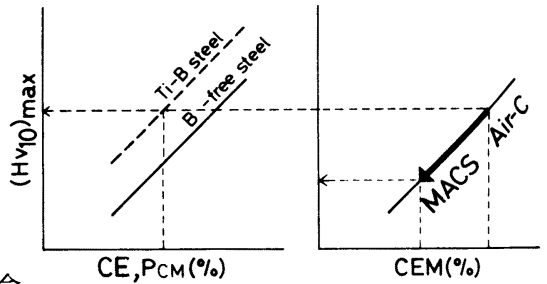

Fig. 5 Lowering of HAZ Hardness by MACS 発した。本鋼管は継手硬度試験,インプラント試験等において優れた溶接性を示した。 
（488）高強度ラィンパィプ用鋼管の機械的性質と耐水素誘起割れ特性 （新厚板製造法による $\mathrm{T} i-\mathrm{B}$ 系 U O E 鋼管の開発一第 3 報 ）

川崎製鉄林葉製鉄所

技術研究所
○中川一郎、白石昌司、上田依孝

戸塚信夫、木村光男

1. 緒言

近年のラインパイプ材には、その厳しい使用環境に応じて厚肉・高強度・高勒性化だけでなく耐 $\mathrm{H} I$ C ( 水素誘起われ) 特性向上・現地溶接性向上が要求される。今回、新制御冷却法（ＭＡＣＳ）の低 C 一 $\mathrm{Ti}-\mathrm{B}$ 系鋼への適用により、従来の制御圧延法（ＣＲ）適用の $\mathrm{Nb}-\mathrm{V}$ 系鋼飞比較して機械的性質术よ び耐 H I C 特性にすぐれた高強度ラインパイプ用鋼管を開発したので報告する。

2. 実験方法

C : $0.04 \sim 0.05 \%, \mathrm{Mn}: 1.40 \sim 1.60 \%, \mathrm{Nb}: 0.03 \sim 0.04 \%$ 成分系で、その他合金成分として $\mathrm{Ti}$, $\mathrm{B}, \mathrm{Al}$ 適宜添加した鋼を 150 ton転炉で溶製し、M A C S 適用鋼板とC R 適用鋼板の機械的性質およ ひ酎 H I C 特性を調查した。また比較として、従来の Nb-V系鋼の M A C S 適用鋼板とC $\mathrm{R}$ 適用鋼板の

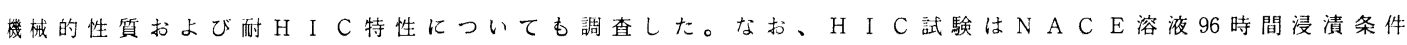
で標準試験片を用いて実施した。

3. 実験結果

1) M A C S 適用による強度上舁効果は、 $\mathrm{Nb}-\mathrm{V}$ 系鋼の方が低 C $-\mathrm{Ti}-\mathrm{B}$ 系鋼に比較して著しく、強 度 ・鞎性の制御冷却条件依存性は $\mathrm{Nb}-\mathrm{V}$ 系鋼の方が顕著である。低 $\mathrm{C}-\mathrm{T}$ - $-\mathrm{B}$ 系鋼の M A C S 適用鋼 板は均質で微細なべィナィト組織を有する鋼板となる。M A C S 適用鋼板はC R 適用鋼板に比較して セパレーション発生が減少するため、D D T T 特性の $85 \%$ S A T T はや高温側へ移る。

2) 低 $\mathrm{C}-\mathrm{Ti}-\mathrm{B}$ 系鋼の M A C S 適用鋼板は、低 C 化と制御圧延条件の緩和によって、従来の $\mathrm{Nb}-\mathrm{V}$ 系鋼の C R 適用鋼板に比較して、われ伝播に奇与する異常組織の減少、中心偏析部硬度低下を可能と し、耐 HIC特性にすぐれた鋼板となる。

3) M A S 適用鋼板のパイプ寸法形状は従来の C R 適用鋼板と同等レベルであり良好であった。

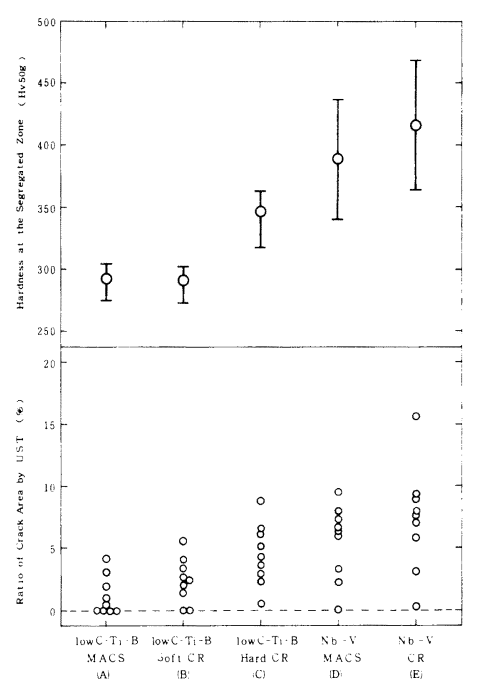

Fig 1 Results af itle Test

Table 1. Chemical Composition of Stcels Investigated
\begin{tabular}{|c|c|c|c|c|c|c|c|c|c|c|c|c|c|c|}
\hline Ste e I & C & $\mathrm{S}_{1}$ & Mn & P & S & Nb & V & A I & T & B & N & Others & Ceg & PCM \\
\hline A, B, C & 0.04 & 0.25 & 1.58 & 0.011 & 0.0009 & 0.038 & - & 0.050 & 0.017 & 0.0008 & 0.0042 & Ca & 0.31 & 0.13 \\
\hline D & 0.08 & 0.27 & 1.53 & 0.013 & 0.0008 & 0.031 & 0.047 & 0.034 & - & - & 0.0044 & Ca & 0.35 & 0.17 \\
\hline E & 0.08 & 0.28 & 1.54 & 0.008 & 0.0010 & 0.037 & 0.063 & 0.030 & 0.009 & - & 0.0045 & $\mathrm{Cu}, \mathrm{N}, \mathrm{Ca}$ & 0.37 & 0.18 \\
\hline
\end{tabular}

\begin{tabular}{|c|c|c|c|c|c|c|c|c|}
\hline \multirow[b]{2}{*}{ Stee 1} & \multirow[b]{2}{*}{ Process } & \multirow[b]{2}{*}{$\begin{array}{l}\text { Finish- } \\
\text { Rolling } \\
\text { Temp } \\
\text { ('C) }\end{array}$} & \multirow[b]{2}{*}{$\begin{array}{c}\mathrm{YS} \\
\text { (MPa) }\end{array}$} & \multirow[b]{2}{*}{$\begin{array}{c}\text { TS } \\
\text { (MPa) }\end{array}$} & \multirow[b]{2}{*}{$\begin{array}{l}E_{1} \\
\text { (96) }\end{array}$} & \multirow[b]{2}{*}{$\begin{array}{l}\text { YR } \\
\text { (\%) }\end{array}$} & \multicolumn{2}{|c|}{ Charpy Test } \\
\hline & & & & & & & $\begin{array}{c}v E-20 C \\
(J)\end{array}$ & $\begin{array}{l}50 \% \\
\text { FATT } \\
(C)\end{array}$ \\
\hline A & $\mathrm{MACS}^{*}$ & 765 & 481 & 580 & 52 & 83 & 338 & -104 \\
\hline B & Soft $C R$ & 680 & 487 & 552 & 52 & 88 & 323 & -100 \\
\hline C & Hard C R & 670 & 535 & 595 & 50 & 90 & 366 & -85 \\
\hline D & $\mathrm{MACS}^{*}$ & 780 & 491 & 632 & 41 & 78 & 308 & $-y_{1}$ \\
\hline E & $C R$ & 690 & 531 & 582 & 48 & 91 & 347 & -105 \\
\hline
\end{tabular}

(Plate Thickness $25.4 \mathrm{~mm}$ * Cooling Rate $10 \mathrm{C} / \mathrm{S}$ ) 
（489）継目無鋼管の水素誘起割れおよびブリスタ一特性に対する - 考察

川崎製鉄怢）知多製造所 ○鈴木和男 寺田利坦 西 博

技術研究所中井揚一 戸塚信夫 木村光男

\section{1. 緒 言}

一般的に継目無銅管の水素誘起割れ（ＨＩＣ）感受性は低いとされ て打り、従来あまり問題視されなかったが、の場合主にB P 試験条 件に対しての結果である。ところがN A C E 溶液のような低 $\mathrm{p} \mathrm{H}$ 領域 の厳しい環境下では耐H I C 対策鋼といえどもブリスターが発生して いる。そこでブリスターレス鋼管の開発を目的としてこのブリスター の発生原因を調査した。

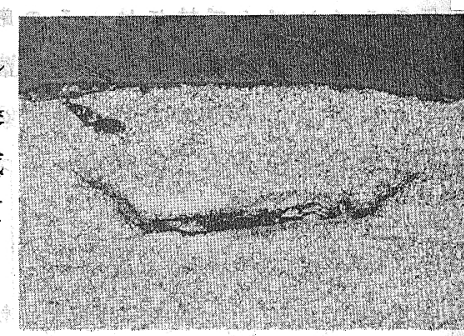

Photo. 1 Observation of Blister

(Transverse section $(X 100))$

転炬出鎆－R H 処理一連続鋳造に上り Table 1 に示す化学 成分範囲のブルームを製造し、マンネスマンプラグミル方式 にて継目無鋼管とした。試験はＢＰ試験片をN A C E 溶液に 96 時間浸漬する方法で行った。試験後、耐 H I C 評価は、 U S Tによる割れ面積率、耐ブリスタ一性は表面観察による ブリスター個数で評価した。

Table 1. Chemical composition of steels (wt. $\%$ )

\begin{tabular}{|c|c|c|c|c|c|c|c|c|c|}
\hline $\mathrm{C}$ & $\mathrm{Si}$ & $\mathrm{Mn}$ & $\mathrm{P}$ & $\mathrm{S}$ & $\mathrm{Cu}$ & $\mathrm{Ni}$ & $\mathrm{A} 1$ & $\mathrm{Ca}$ & $\mathrm{O}$ \\
\hline 0.07 & 0.20 & 0.90 & & 0.0007 & & & 0.025 & & \\
2 & 2 & $?$ & $\leqq 0.015$ & 2 & $\leqq 0.02$ & $\leqq 0.02$ & 2 & $\leqq 0.080$ & $\leqq 0.0025$ \\
0.15 & 0.30 & 1.40 & & 0.0100 & & & 0.035 & & \\
\hline
\end{tabular}

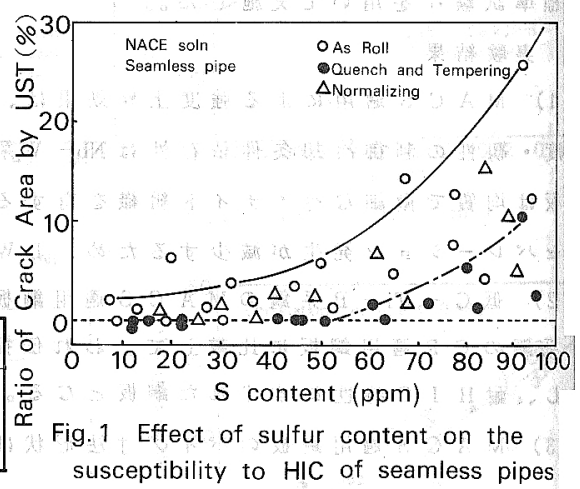

\section{3. 調査結果}

(1)継目無鋼管の場合、厚板あるいは hot 材に比べH I C は 低くQ T 材では低硫化のみで耐 H I C 鋼の製造が可能 （Fig. 1) 。ただし、As Roll 管では低硫化と共にCaの 適量添加 $(20 \sim 50 \mathrm{ppm})$ が必要である( Fig. 2$)$ 。

(2)ブリスターの原因は鋼表面下の大型介在物であり、 $\mathrm{S}$ 量 にかかわらず発生するが、 $\mathrm{Ca}$ の適量添加は大型介在物 の減少に効果がある。

(3)介在物低隇対策による鋼中非金属介在物の隇少により、 ブリスターレス鋼管の製造が可能であるが、As Roll材 では Q T 材に比べより厳しい介在物対策が必要となる。

4. 参考文献

1）寺崎他：住友金属技報、Vol 30 N. 1（1978）

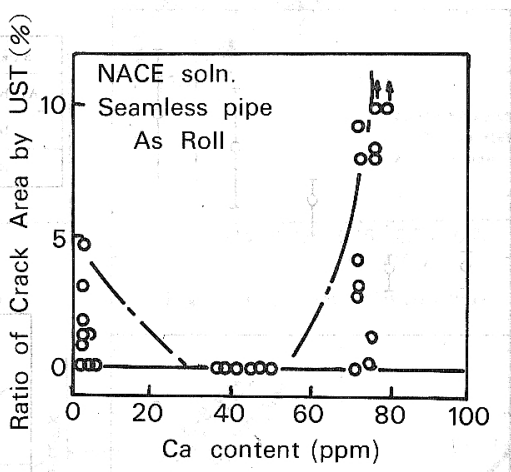

Fig. 2 Effect of calcium content on the susceptibility to HIC of Seamless pipes. 
(490) c リング試験による油井用電縫鋼管溶接部の硫化物応力腐食割れ特性評価の試み 新日鐵名古屋技術研究部。山田勝利 新日鐵名古屋製鐵所村山博

1. はじめに

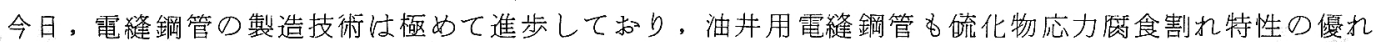
たものが，容易に製造出来るようになってをている。

本報ては, 電縫鋼管の流化物応力腐食割れ特性評他法の検討の一壊として, 電縫溶接部の特性評佂の 観点からCリング試験法につりて検討し，さらに調質型油井用電縫鋼管の溶接部と母材部の比較を敊と なった結果を報告する。

2. 試験方法および供試材

Cリング試験方法は，Vノッチを有する 試験片に一定の応力を負荷して腐食液中に 浸漬し破断するまでの時間を検出する方法 に上った。腐食液は, $5 \% \mathrm{NaC} 1$ 水溶液に

$\mathrm{CH} \mathrm{C}_{3} \mathrm{COOH}$ を添加して $\mathrm{pH}$ を 3 とし

Table.1 Chemical composition of steels and ERW pipe size

\begin{tabular}{|c|c|c|c|c|c|c|c|c|c|c|c|}
\hline \multirow{2}{*}{ Steel s } & \multicolumn{11}{|c|}{ ladle analys is (wt. $\%$ ) } \\
\hline & C & $\mathrm{Si}$ & $\mathrm{Mn}$ & $P$ & $\mathrm{~s}$ & $\mathrm{Ti}$ & B & T.A & $T \cdot N$ & $\mathrm{Cu}$ & REM \\
\hline $\mathrm{Cu}-\mathrm{Ti}-\mathrm{B}$ & 0.26 & 0.195 & 1.19 & 0.017 & 0.003 & 0.025 & 0.0013 & 0.022 & 0.0041 & 0.28 & - \\
\hline $\begin{array}{l}\mathrm{Cu}-\mathrm{Rem-}- \\
-\mathrm{Ti}_{\mathrm{i}}-\mathrm{B}\end{array}$ & 0.26 & 0.195 & 1.19 & 0.017 & 0.003 & 0.025 & 0.0013 & 0.022 & 0.0041 & 0.28 & 0.012 \\
\hline
\end{tabular}

(EFW pipe size $51 / 2 " \not \times 0.361^{\prime \prime}$ )

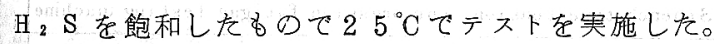

供試材は, 表 1 亿示す化学組成を有し種々の温度て焼戻して種々の硬さを有する 調質型油井用電縫鋼管である。

\section{3. 試験結果および考察}

図 1 亿示すよらな割れ発生を検出する手法を考案し、Cリング試験を行孛った。 $\mathrm{T}$ i - B 系の調質型油井用電縫鋼管の破面

観察の結果，

(1)、破断は脆性的てはなく、凹凸が激しい。

(2). しかし, 純粋な H I Cの上5反介在物 を伝わった割れではなく，HＩCと H Eの 混在状態とみられる。(3)・旧オーステナ イト粒界割れと粒内割れの両方が混在して みられる，ととが明らかとなった。

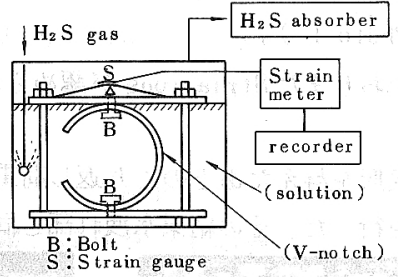

Fig.1 C-ring SCC test method.

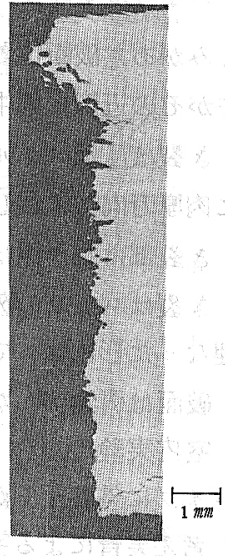

Photo.1 A section of SCC failure. (weld notched)

さらに, 表 1 にしめす調質型油井用電縫鋼管につい て，溶接部と母材部とにそれぞれVノッチをつけたC リング試験片によりテストを実施しを結果，

(1)・破断するまでの㭙間でみると，溶接部と母材部と の差壮みられない。

(2)、また，介在物形状制御の効果は鋼の強度が比較的 低々 A P I N - 800低目側飞和いて顕著にあらわれ る：ととが判明した。

4. まとめ

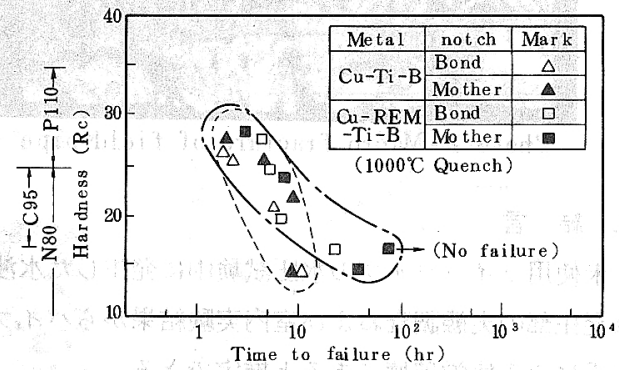

Fig.2 C-ring SOC test results.

C リング試験法により，調質型油井用電縫鋼管の溶接部と母材部の比較を和乙なった結果，溶接部々 昷材部の硫化物忍力腐食割れ特性に差異は見られず，優れた品質水準であるととが明らかとなった。 参考文献 1) C. M. Hudgins, R. L. MeGlasson, Corrosion, Vol.22, Aug. 238，(1966) 
$' 84-\mathrm{S} 492$

(491) 未使用ラインパイプの損傷解析

新日本製鐵（株）八幡技術研究部

○八 明 西田新一

東山博吉 浦島親行

八幡製鐵所技術部 岡田英樹 梶木悦治

\section{1. 緒 言}

北米アラスカに施設したパイプラインの使用開始前のフィールド水圧試験中に水洩礼事故が発生した。水洩れ 発生部（ 5 筍所）には打ち傷あるいはき裂が認め引れその実態調査を行った結果, さ裂は製管, 出荷以降の輸送 中に発生した疑いがもたれた。そてでき裂部の調査解析に加光輸送中のパイプ破壊の可能性および破壊発生，层 播のメカニズムを考察するための室内実験を行った。

2. 調查, 実験方法

（1）水洩れ発生部の調査；現地から返送された水洩れ発生部の外観調査るよび破面，断面ミクロ観察を主に実施。

（2）室内実験；同一鋼種のパイプを使用し実験条件の一例をTable 1 亿示す。

3. 結 果

（1）水洩れ発生部

(1) パイプ外表面に打ち傷あるいは へとみがあり破断位置およびき裂の 発生がその近傍に集中している。

(2)き裂は圧延メタルフローと無関

Table 1. An example of fatigue test condition

係に肉厚方向に進展し粒内破壊もみられ枝分れしたものもある。

(3)き裂部に眖炭層はない（すなわち熱間ワレではない）。

(4)き裂はパイプの外表面, 内表面から別々に発生し，しかも破面はなめらかで段状になっており肉厚中心付近 で連なった形になっている(Photo 1 )。

(5) 破面は瓷食がかなり進んでおりまたtriationsが認められる。

(2) 室内実験

パイプに外表面側から塑性変形を与えたあとのくり返し荷重を想定すると残留応力が重畳して部分片張りとな ると考光実管による室内実験を行った。その結果水洩れ部と同樣な破壊現象が確認された（Fig 1，Photo２）。

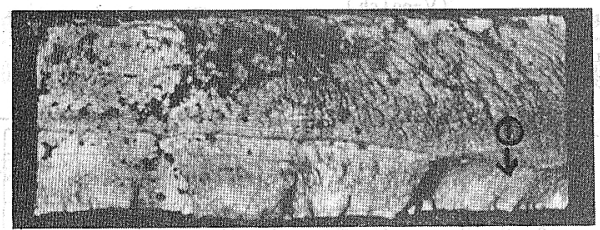

Photo 1. Macro fracture of field pipe

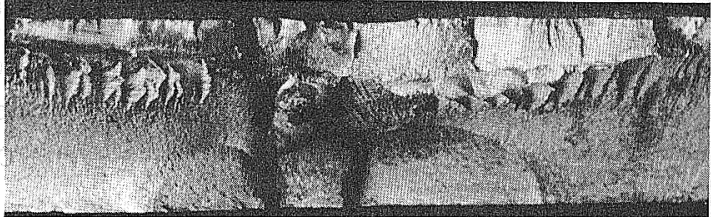

Photo 2. Macro fracture of test pipe

\section{4. 結 言}

未使用ラインパイプの水圧試験中に発生した水洩机事故原因は水洩 れ発生部の実態調査および室内実験結果からパイプ輸送中のくり返し 荷重による疲労破壊であると推定できる。

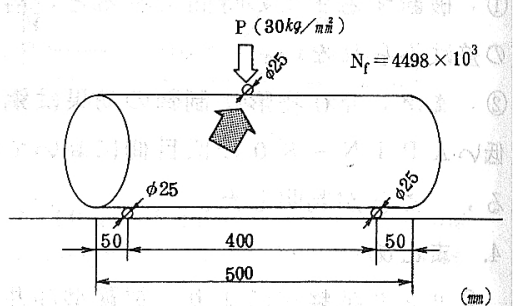

Fig 1. Cracked position of test pipe 


\title{
(492) Cuの析出硬化を利用したラインパイプ用厚鋼板の開発
}

\author{
新日本製鐵(制)君津技術研究部门村田正彦為広 博
}

山田直臣南雲道彦

1. 緒言

Gu析出硬化鋼については古くより研究され，多数の研究が発表されているが，熟間圧延時の Cu一 $ク ラ ッ ク$ 等の問題から耐食鋼等極めて限定された用途にしか実用化されていない。しかし，含 持つ高強度はラインパイプにとつて䰠力であり，また，極低温加熱圧延技術，高純度鋼溶製技術の開発 により，製造上の問題点も解決される方向にある。本報告では含 C u ラインパイプ用厚鋼板の実験室検 討の結果について述べる。

\section{2. 実 験 方 法}

実験室溶解圧延により，高純度鎝（低 $\mathrm{P}, \mathrm{S}, \mathrm{N}$ ) を基本に材質，割れ性等に対する $\mathrm{Cu}$ 添加量， $\mathrm{N}$ ， 微量 $\mathrm{Nb}$ の影響について調查した。加熱温度は $\mathrm{Cu}$ 酸化物の融点（約 $1083{ }^{\circ} \mathrm{C}$ ）以下の低温加熱(950 $\sim 1050 \mathrm{C})$ と ，制御王延後，焼戻処理（550 C × 10 分空冷）を実施した。板厚はすべて $20 \mathrm{~mm}$ で る。

\section{3. 実験 結 果}

1) $\mathrm{Cu}$ 添加量が $1 \%$ になると析出硬化が顕著となり，焼戻処理 によって T S が約 $10 \mathrm{~kg} / \mathrm{mm}^{2}$ 増加する。vTrS は劣化するがレべ ルは良好である(Fig.1)。

2) $1 \% \mathrm{Cu}$ 銅のミク口組織は低温加熱一制御圧延によって非常 に細粒 $\left(\mathrm{N}_{0} \approx 11.0\right)$ であり，電顕観察によるとフェライト地中に Cuと思われる多数の微細析出物が観察される(Photo. 1, 2)。

3） $\mathrm{HAZ}$ 勒性は $0 \sim 1 \% \mathrm{Ou}$ の範囲で， $\mathrm{Cu}$ 添加量に依らず著し く良好である。

4) 低温加熱にす扎ば，加熱生旇中の $\mathrm{O} u$-クラック防止のため に, N i 添加は不要である。また $1 \%$ ～u 銅では材質上も必要 としない。

5）Ｎｂ低温加熱においてもミク口組織の細粒化に有効である が，量的には $0.01 \%$ 程度で十分である。

以上より， $\mathrm{N}$ 添加しなくても $1 \% \mathrm{Cu}$ 鋼の母材，溶接部の強靱 化は可能で, $-60{ }^{\circ} \mathrm{C}$ 程度の低温使用高強度ラインパイプ用厚鋼板と して有望である(Fig. 2 )。

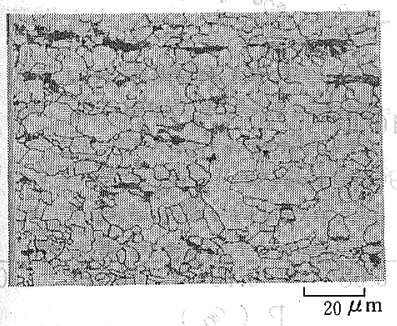

Photo 1 Microstructure of $1 \% \mathrm{Cu}$ stee.

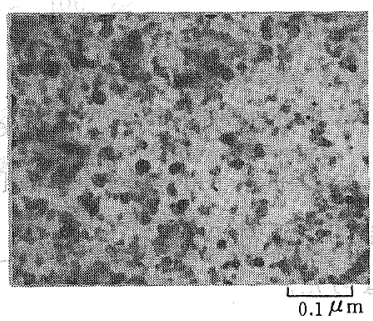

Photo 2 Transmission electron micrograph of $\mathrm{Cu}$ precipitates.

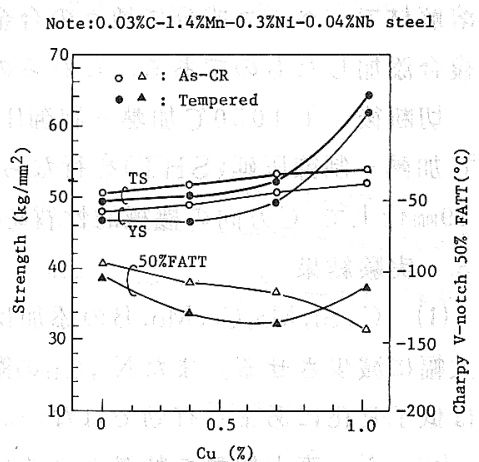

Fig. 1 Effect of $\mathrm{Cu}$ content on the mechanical properties.

Nòte: (1) $\mathrm{x} 70,0.05 \% \mathrm{C}-1.5 \% \mathrm{Mn}-1 \% \mathrm{Cu}-0.01 \% \mathrm{Ti}$

(2) Test position

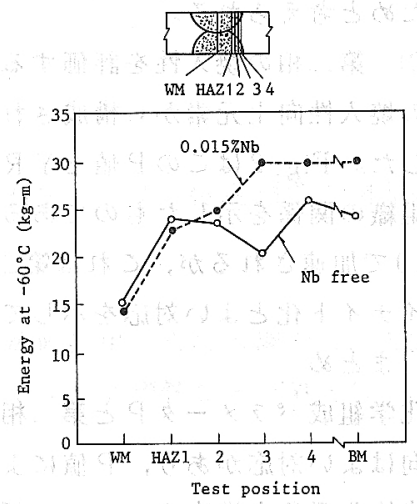

Fig. 2 Charpy V-notch energy of double submerged arc weld joint at different test positions. 
1. 緒言

近年, 厚鋼板における高張力化は目ざましいものがあるが, 構造物の安全性や冷間加工性改善の観点 からか, 降伏比（以下 Y R ）の低い高張力厚鋼板の需要が高まってきている。しかしながら, 厚鋼板の 低 Y R 化技術に対しては, Mo 等合金元素の調整や压延後の水冷処理によって対処されている屯のの, 合 金元素や加熱圧延（水冷）条件とYRの関係は十分に解明されているとは言えず，材質設計上，系統的 な研究が望まれている。本報では，制御压延材の低 $\mathrm{Y} R$ 化の基礎検討として，Y R 亿及ぼす合金元素の 影響を第二相のミクロ組織に注目して調查し,さらに Table I Chemical composition (wt \%) 低Y R 鋼の材質予測に対して若干の検討を加えた。 (a) Basal steels

\section{2. 実験方法}

供試鋼の化学組成をTable I に示す。いずれも真空 溶解材で, ベース成分に種々の合金元素を単独または 複合添加したものである。これらのインゴットを鍛造 一切断後, (1) $1050^{\circ} \mathrm{C}$ 加熱一制御圧延 (CR), (2) 900 ${ }^{\circ} \mathrm{C}$ 加熱一制御压延 (SHT)を行なった。ともに $700^{\circ} \mathrm{C}$ $19 \mathrm{~mm}$ 仕上で, C方向の機械的性質を調查した。

\section{3. 実験結果}

(1) $\mathrm{C}, \mathrm{Si}, \mathrm{Mn}, \mathrm{Cr}, \mathrm{Mo}, \mathrm{B}$ の添加は $\mathrm{Y} \mathrm{R}$ を 大幅に減少させる。また $\mathrm{Ni}, \mathrm{Cu}$ の微量添加 は低Y R 化にあまり有効ではない。(Fig. 1)

(2) Ac 3 直上加熱を特徴とする S H T 圧 延は低Y R 化を促進する。(Fig. 1) 乙れは オーステナイトの微細化によりフェライト 変態が促進され，第二相の合金濃度が高ま るためと考えられる。

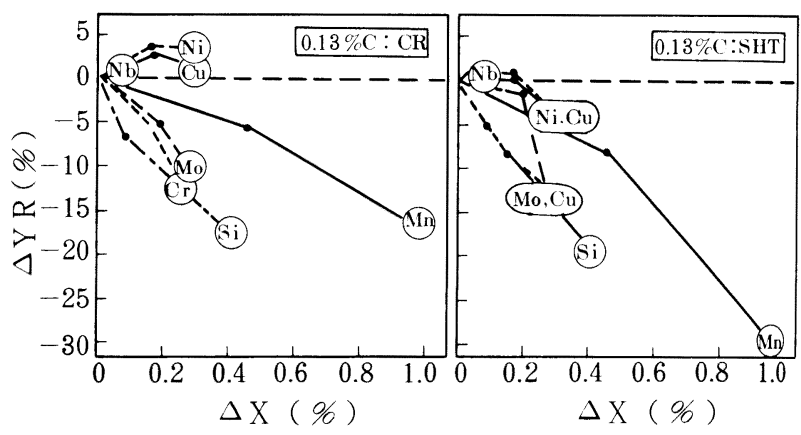

Fig. 1 Effect of alloying elements on yield ratio.

（3）第二相の焼入性を評価する手段として，炭素以 外の焼入性向上元素から構成されるパラメータ $\mathrm{P}$ を導 入した。Fig. 2 はこのP 值とYRおよび第二相のミク 口組織の関係を示したものである。低 $\mathrm{Y} R$ 化は $\mathrm{P} \geq$ 0.10 で加速されるが，乙れは第二相のマルテンサイト， ベイナイト化とよい対応を示している。

4. まとめ

化学組成パラメータ $\mathrm{P}$ と第二相のマルテンサイト化 傾向はよい対応があり，P值によって制御压延材の低 降伏比化現象を推定するととが可能となった。

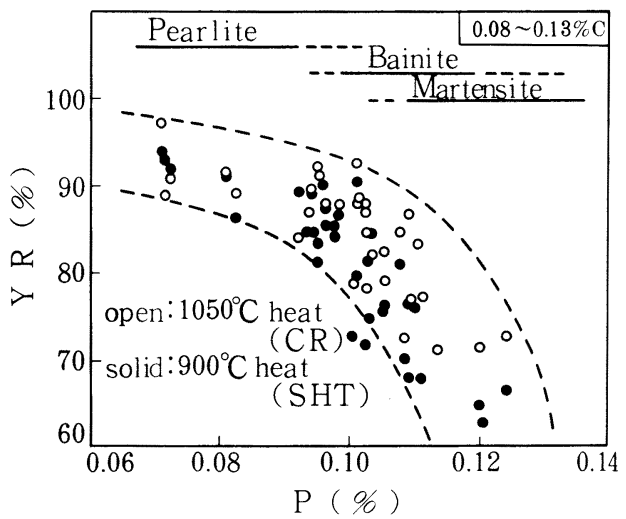

Fig. 2 Relation between $\mathrm{P}$ value and yield ratio. $(\mathrm{P}=\mathrm{Si} / 30+\mathrm{Mn} / 20+\mathrm{Cu} / 20+\mathrm{Ni} / 60+\mathrm{Cr} / 20+\mathrm{Mo} / 15+5 \mathrm{~B}(0 /)$ 


\section{(494) スラリー輸送鋼管の損耗機構に関する実験的考察}

新日本製鐵 中央研究本部

鋼管研究センター

井上史 朗

\section{1. 緒 言}

スラリー輸送鋼管は、直管の底部および曲管の側壁に, 溶液による腐食損耗に比べ, はるかに激しい 損耗がおこる。この原因を水平配管に硅砂スラリーを流す方式の試験を行なって調査した。その結果に もとづいて, 直管および曲管の損耗機構を考察した。

\section{2. 試䣯条件}

スラリー; 水道水士J I S 10 号硅砂, スラリ一重量濃度 $40 \%$ 流速 ; $2.4 \mathrm{~m} / \mathrm{sec}$

試験時間； $500 \mathrm{hr}$

試験片寸法； $30 \times 100 \times 3$

\section{3. 試験結果}

$3-1$ 直管の場合

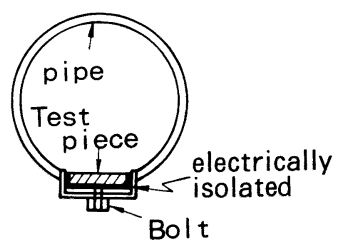

i ) 試験片の損耗量とかたさとはよい相関がない。

ii）しかし, 試験片を腐食形態別に分けると, 試験 片かたさと損耗量はよい相関性をもつ。（Fig.2） iii）損耗量はスラリーの温度の影響を大きく受ける。 $3-2$ 曲管の場合

i ）損耗は流れの外側にあたる管壁の 1 ケ所に集中 しておこる。

ii）損耗面はS U S 304 鋼管の場合, 超仕上面に なる。

iii）損耗開口部周辺は箔になる。

iv）損耗速度は直管に比べ極めて大きい。

Fig.l Test piece setup

\section{4. 損耗機構の推察}

直管は主として，スラリーにより加速された腐食に

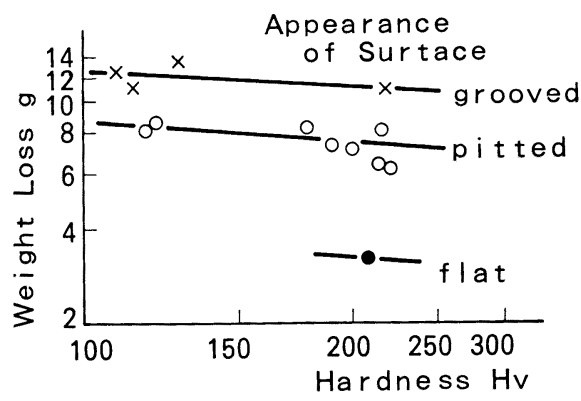

Fig. 2 Relatjon between Weight hossand Hardness by a Sand SIurry Test よって損耗をおこす。曲管はスラリーによる研削によ って損耗をおてす。したがって、スラリ一鋼管は，直管 あ曲管もかたさを重要視するのは間違いであると考える。

なお，直管の損耗が加速腐食によることは，3年間使用した実用の石炭スラリー輸送鋼管の調査結果 でも確認できた。

\section{5. スラリー用鋼管の条件}

直管は耐食性を考慮した鋼管であるものが望ましい。曲管および乱流域に用いられる鋼管は, 表面に 弾力性を持たすことが肝要であると考える。例えば，ポリウレタンライニング鋼管などが望ましい。 
' $84-\mathrm{S} 496$

（495）径方向变泣計による高マンがン鋼の極低温引張变形学動の観察

金材研筑波 ○長井寿，由利哲美，中曾根祐司，石川圭介

1. 緒言極低温利用技術の発展に伴って，極低温用洅造 材料の機械的性筫の正確な評価が求められている。しかし、 液体へリウム温度付近における变位・歪の剆定などの基本 技衍においても碓たる即定方法は未確立である。さらに極 低温下においてはセレーション变形が生じ，变位・歪の正 磪な測定をより困難にしている。光こで、本研究では歪ゲ 一ジ式径方向变位計(浸清型)を用いて，高マンがン铜の 極低温下における一軸引張による変形拳動について調べ， 極低温での变位測定についての基本的知見を得ることを目 的にした。

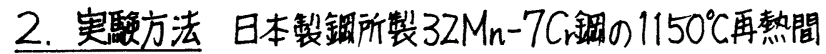
压延材を用い，全長 $80 \mathrm{~mm}$ ，平行部 $30 \mathrm{~mm}$ ，平行部往3.5 $6.5 \mathrm{~mm}$ の丸棒引張試騟片を作製した。经方向变位計は平行 部のほぼ中央に装着し、光の点における径方向变位のみを 測定するようにした。引張試㛐機はインストロン型で、ク ロスヘッド速度は主として $1 \mathrm{~mm} / \mathrm{min} て ゙$ 行った。荷重・变位 の計測には、精度の良い自動測定とディジタル処理を可能 にするために，16ビットマイコンによる自動計测装置を試 作して用いた。

3. 実験結果 (1)歪ゲージ式变位計は。ゼロドリフト，出 力の温度依存性があるが、極低温においても直線性は良好 で，出力を補正することにより極低温での变位の測定が十 分可能である。(2)得られた応力一经方向䄳曲線(四1)は。特有の性状 を示している。ヒレーション発生時には，セレーション变形域外は弹性 的に橵張し，セレーション变形域では最大 $2 \%$ 前後の急激な収縮力激察 される。測定点がセレーション变形域に含まれる確率は15 20\%である （四2）。(3)液体へリウム温度での强さ，伸びは径の大きさにほとんど 依存しないが,セレーション变形開始变位は大きく变化する(国ろ)。 4. 結言 歪ゲージ式变位計による杨低温の变位測定自体は比較的容易 である。しかし，セレーションを伴う場合，变位のモニタとしての径方 向变位計の使用には、十分な留意が必要である。

なお，本研究は科学枝街仃の昭和57年度科学枝術振興調整費による 超電尊・極低温基盤技術の開発に関する研究」の一環として行われたも のの成果の一部である。

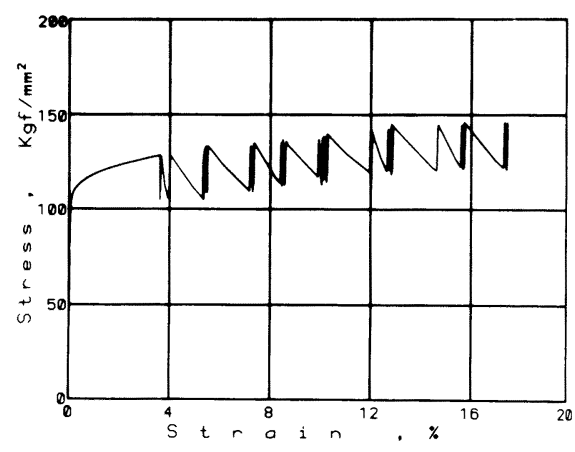

Fig.1 Stress-radial strain curve for $4.5 \phi$ specimen at $4 \mathrm{~K}$.

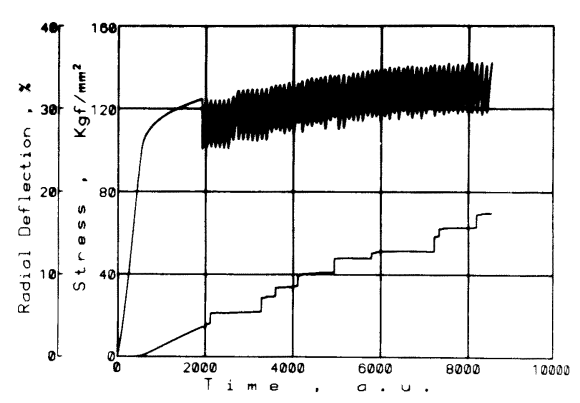

Fig.2 Changes of stress(upper) and radial deflection(lower) for $4.5 \phi$ specimen at $4 \mathrm{~K}$.

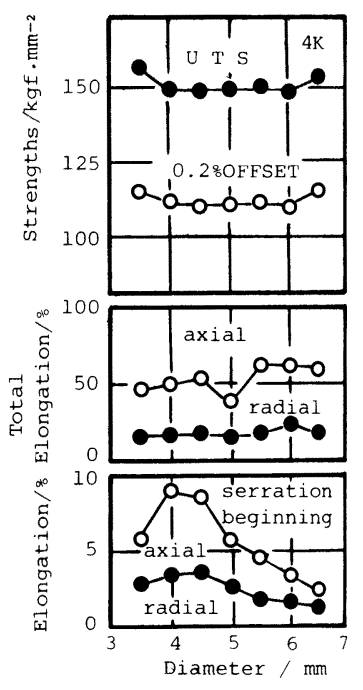

Fig. 3 Tensile properties as a function of gage diameter 
' $84-\mathrm{S} 497$

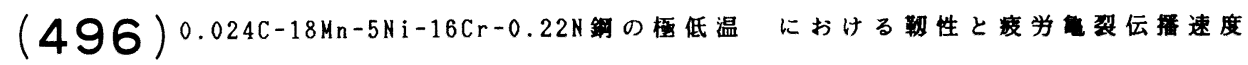

秼神戸製鍮所浅田研究所。小川陸郎

LBL, Univ. of California, Berkeley J.W.Morris, Jr.

\section{1. 緒 言}

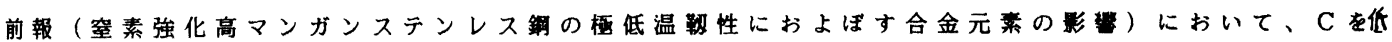

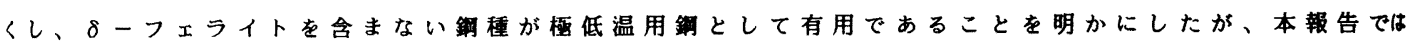

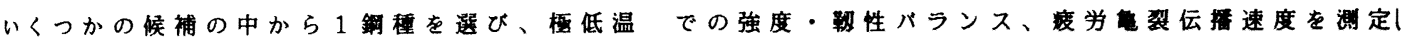
婳低温用鈮としての評価を行ったのでその結果を報告する。

2.試料および実験方法

$18 \mathrm{Mn}-5 \mathrm{Ni}-16 \mathrm{Cr}$ 銅を $300 \mathrm{~kg}$ 真空溶製した。化学成分は C $: 0.024 \%, \mathrm{Mn}: 17.98 \%, \mathrm{Ni}: 4.96 x, \mathrm{Cr}: 16.26 \%$, $\mathrm{Si}: 0.53 \%, \mathrm{~N}: 0.216 \%, \mathrm{P}: 0.004 \%, \mathrm{~S}: 0.01 \%$ である。インコットは80na厚さに熱間鐉造の後、過熱温度 を変えた 3 条件 $\left(1250^{\circ} \mathrm{C} 、 1200^{\circ} \mathrm{C} 、 1150^{\circ} \mathrm{C}\right)$ で、30 m mに熱間压延した。压延まま、溶体化处理 $\left(1050^{\circ} \mathrm{C} \times 30^{\circ}\right.$ 分 水冷)、30\%の冷間加工を加えた板の 3 種の板より、引張り試験片、C $\mathrm{T}$ 試験片を切り出し、77K,4Kで 引張り試験、除荷コンプライヤンス法J゙の測定、疲学裂伝播速度の渭定を実施した。

\section{3. 実験結果および考察}

Fig. 1 に $4 \mathrm{~K}$ でのK।C (J)と降伏強さの関係を示す。図中には、304N,304LN鋼について報告されている

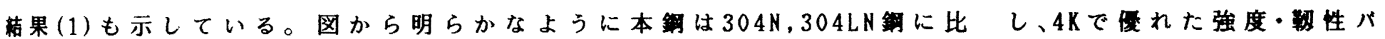
ランスを示している。压延温度を下けると強度が上昇するが、踙性の低下が大きい。組糡钼察の結果 强度上昇は細粒化效果に上ることがわかったが、細粒化により勒性は低下する。冷間加工は強度を著 しく上昇させるが、鞄性の低下は少なく、高強度化をはかるには有奻な方法である。

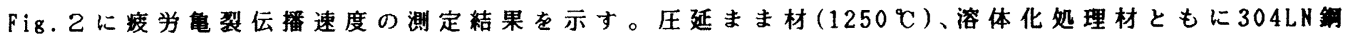

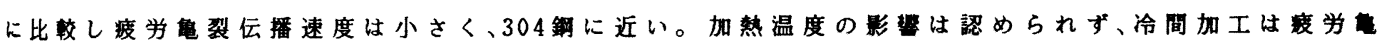

裂伝播速度を若干低下させる。

(1)D.T.Reed and R.P.Reed:Materials Studies for Magnetic Fusion Energy Applications

at Low Temp. -1

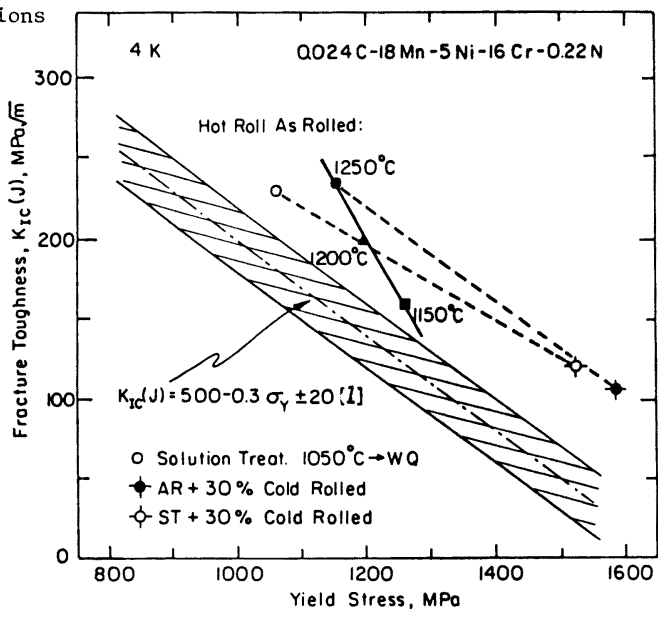

Fig. I Strength and toughness combination at $4 \mathrm{~K}$

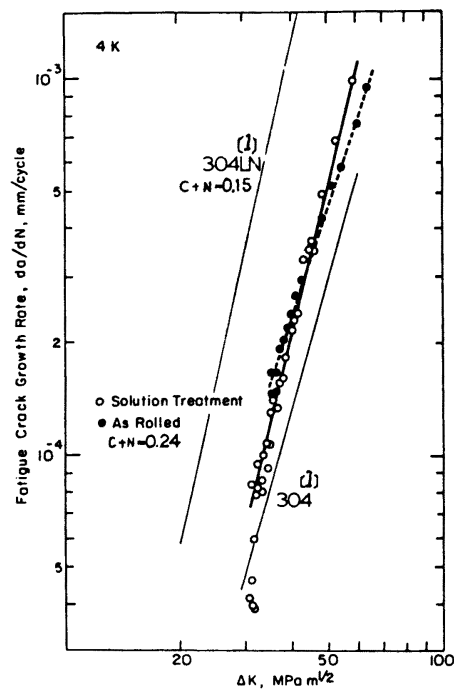

Fig.2 Fatigue crack growth rates 


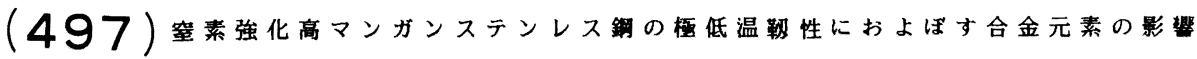

踭神戸製銅所浅田研究所口小川陸郎

LBL, Univ. of California, Berkeley J.W.Morris, Jr.

1. 緒言

最近の超伝導応用技術の発達はめざましく、とくに核融合研究の分野で大型の超電導コイルが建設さ れはとめており、発生する大きな電磁力を支える粠造用龬もコイルの大型化にともなって、極低温で， 高強度、高靱性の材料が必要になっている。本報告では新しい極低温用鎆として窒素強化高マンガ ステンレス鋼を採りあけ、広い範囲の成分について、極低温勒性におよぼす合金元素の影響を調べ,樰 低温用銅としての問題点の抽出を行った。

2.試料およひ実験方法

$0.03 \mathrm{C}-18 \mathrm{Mn}-5 \mathrm{Ni}-16 \mathrm{Cr}-0.25 \mathrm{~N}$ 鎆をbaseに、 $\mathrm{Mn}, \mathrm{Ni}, \mathrm{Cr}$, およひ C，Nの影整を調べる目的で、Mn (15 28\%)，Ni(1 7x) $\mathrm{Cr}(12 \sim 18 \%)$ と変化させた試料およひ、 C+N は $0.28 \%$ と一定で Cを0.03 0.16\%と変えた試料を真空溶製した。各インコット

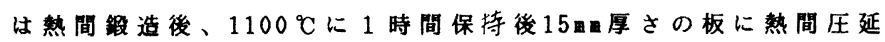
した。压延まま $(A R)$, 溶体化処理 $\left(1050^{\circ} \mathrm{C} \times 30\right.$ 分 $\rightarrow$ 水冷： ST) 溶体化後時奻 $\left(660^{\circ} \mathrm{C} \times 45\right.$ 分 $\rightarrow$ 空冷： ST+ANN)の3条件の板上り引 張りおょびシャルピ一試験片を切り出し、77Kで引張りおょび シャルピー試験、4Kで引張り試験を実施した。

\section{3 . 実験結果おょび考察}

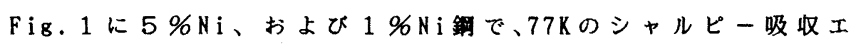
ネルギーにおよぼす林の量の影響を示す。 $5 \%$ Ni龬では28

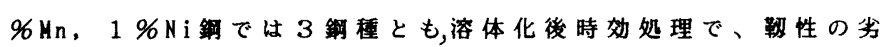
化が認められる。また $1 \% \mathrm{Ni}$ 銅では $5 \% \mathrm{Ni}$ 鋼に比較し、全体 として靱性が低い。このような靶性の劣化は $18 \% \mathrm{Cr}(-5 \% \mathrm{Ni})$ 鎆 にも認められた。組轼観察、透磁率の貺定からこれからの龬 には 8 ーフェライトが含まれることがわかった(Fig.2)。 8 フェライトは $660^{\circ} \mathrm{C} \times 45$ 分の時效です心゙て 6 相に変態することを $\mathrm{X}$ 線、透過霞顕钼察より確認した。 性を劣化させるが、脆い6相に変態することにより著しく脆化 させる。

溶体化後時効処理による勒性の劣化はCを增加させた鋼に おいても钼察された。この揚合明境な粒界破捿が認められ 粒界破面上のAuger電子分光、透過露影钼察上り粒界上の $\mathrm{M}_{23} \mathrm{C}_{6}$ 炭化物による脆化であることがわかった。

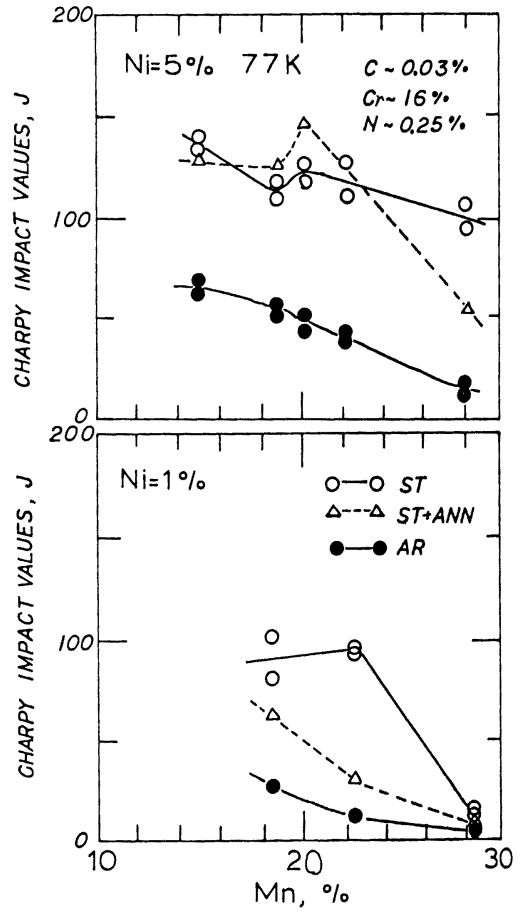

Fig. I Effect of $\mathrm{Mn}$ and $\mathrm{Ni}$ on the Charpy Impact values

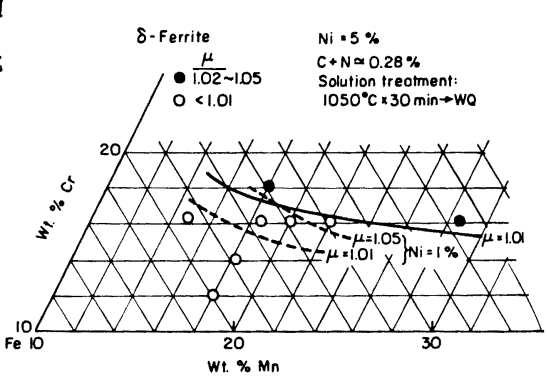

Fig. 2 Measurement of permeability 
(498)時効观理した柯低温用高Mn鋼の鞄性に及ぼす加熱，压延後の冷却条件の影暨

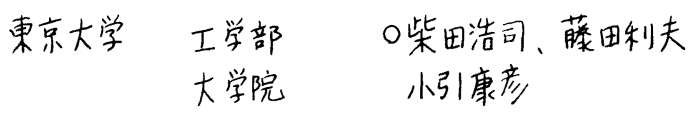

緹言愹体化处理温度から冷却途中、 ちる温度筙囲で保持すると、含C、V

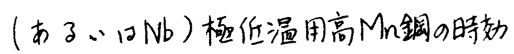
杖の䩓性が向上することをすでに報告 した。本報告では、この現象をさらに

Table 1. Chemical composition of the steel in wt\%.

\begin{tabular}{|c|c|c|c|c|c|c|c|c|c|}
\hline $\mathrm{C}$ & $\mathrm{Si}$ & $\mathrm{Mn}$ & $\mathrm{P}$ & $\mathrm{S}$ & $\mathrm{Ni}$ & $\mathrm{Cr}$ & $\mathrm{V}$ & $\mathrm{Al}$ & $\mathrm{N}$ \\
\hline 0.095 & 0.55 & 32.4 & 0.002 & 0.011 & 0.22 & 6.97 & 0.10 & 0.030 & 0.21 \\
\hline
\end{tabular}

詳しく調べること、鳌间压延後の冷却条件を制御して、時効 材の勒性をさらに上げる可能性を調べること、を目的に行っ た实験結果について述べる。

害酸方法供試材の化学成分をTable 1 下示可。真空愹 解により溶製し、錹造・死延して得た $13 \times 13 \mathrm{~mm}$ の角棒を

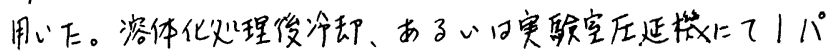
220\%热间压延してから冷却した武料を、時勍观理(973 $K \times 48 h)$ 後 $2 \mathrm{mmV}$ )ッチ標㛙茾イズのシャルピー試联

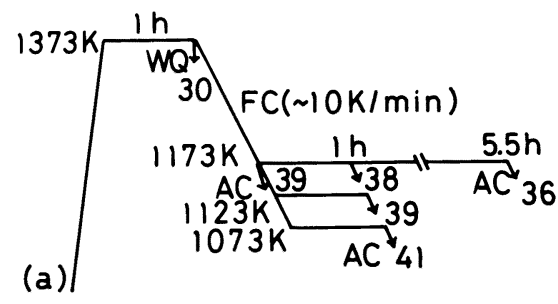
片に工作した。シャルピー試致は77Kで行った。破面, 組 珹をSEM、TEM Eて観察LE。

結果（1)溶体化父理捘、1度冷却してから1073K〜1323

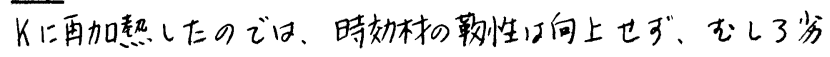
化する。

(2)容体化父理後、徐汿しても時効材の䩓性が向上する。

(3)邻中上部温度轮团で等温保持することによって䩓性が向 上した時効材でほ、結晶粒界析出物が非保持材、例之ば疼体 化观理後水冷したものと軛して少ない。

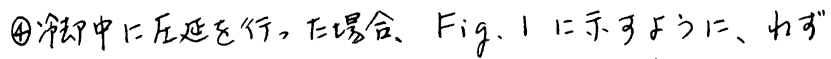
かでリあるが䩓性の向上るる条件のあるここがわかった。

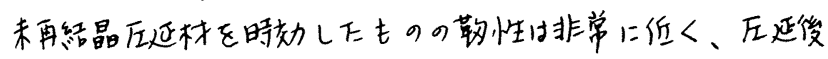
等温保持するなどして再結晶させると䩓性同上する。しゅ し長時间保持しるぎると䩓性曰再げ低下し、非后延材よりも 劣化する。

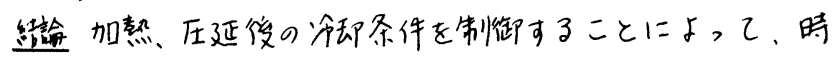
奻材の䩓性を改善することガ出来ることを示施喟を得た。 条件、最通化、成分の調整により、压延まま時効材の低温䩓 性をさらに向上出来るものと考えられる。

文解 1) K. Shibata et al. : Advances in Cryo(b)

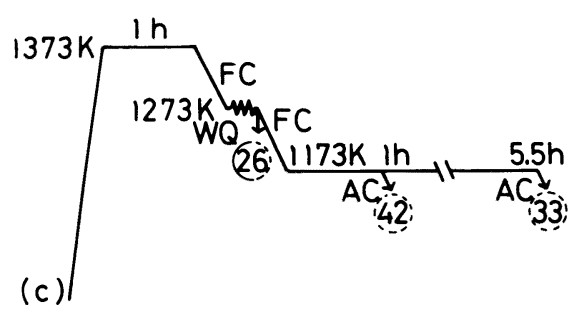

Fig. 1. Effect of cooling condition on Charpy impact energy at $77 \mathrm{~K}$ of the steel aged at $973 \mathrm{~K}$ for $48 \mathrm{~h}$. The impact energy is shown in $\mathrm{J}$. Solid and dotted circles represent non-recrystallized and recrystallized conditions, respectively.

genic Engineering, vol.30, Prenum Pub. Corp. (印刷中), 鉄と铜, 69(1983), S 1481 
' $84-\mathrm{S} 500$

(499)

$30 \% \mathrm{Mn}$ 非磁性 $\mathrm{H}$ 形鋼の製造

川崎製鉄侏) 水島製鉄所

○栗山則行 片山 進

西村 隆

吉田雅一 山下政志 (技研)佐々木晃史

1. 緒言 現在, エネルギ一資源の代替の一環として，世界主要国で核融合炉の開発が推進されている。 その装置部材として非磁性鋼が求められており，その構造部材については非磁性 $\mathrm{H}$ 形鋼の需要が見込ま れている。

今回, 加工性，透磁率の安定化および耐溶接割れ性などの改善をはかった低 C $-30 \% \mathrm{Mn} \mathrm{H}$ 形鋼の製造 を行なったので，以下に報告する。

2. 製造工程今回，製造を行なった H

$350 \times 350$ および $\mathrm{H} 200 \times 200$ サイズの

製造工程を Fig.1亿示す。

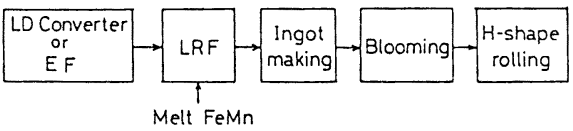

Fig.1 Manufacturing process

3. 製造条件

3.1 化学成分 従来の高 C 系の高 $\mathrm{M} \mathrm{n}$ （ $13 \mathrm{Mn} \sim 25 \mathrm{Mn}$ ) 非磁性鋼は, 難削性あるいは透磁率の安定性不 足などの問題があり， 室内実験を行ない,こ れらの品質改善をはか った $0.25 \mathrm{C}-30 \mathrm{Mn}$ 鎆 とした。

(Fig. 2, 3,4)

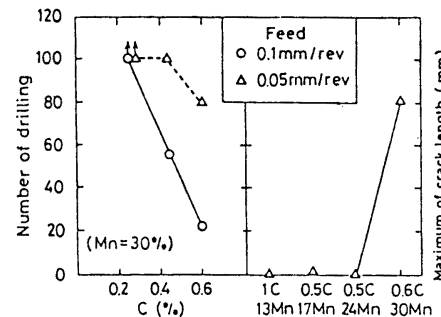

Fig. 2 Result of drill test by high-speed stee

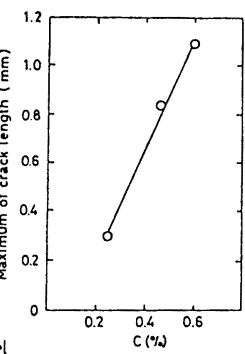

Fig. 3 Result of Trans -

Varestraint testing

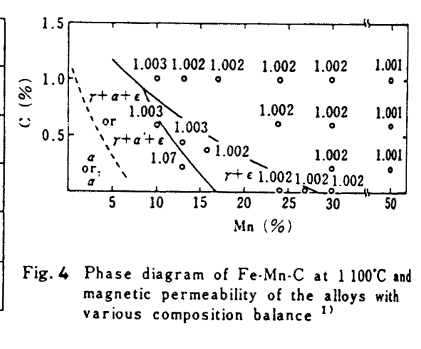
magnetic permeability of the alloys with
various composition balance

\section{2 溶製条件}

(1) M n の酸化防止 $\mathrm{Mn}$ 酸化防止のため, MnO濃度の高いスラグを利用し, Mn歩止は約 $98 \%$ を得た。

(2)耐火物の選定 $\mathrm{Mn}$ による耐火物の浸食を防止するため， $\mathrm{SiO}_{2}$ 濃度の低い耐火物を利用した。

\section{3 分塊および $\mathrm{H}$ 形鋼圧延}

(1)加熱条件 加熱時のバーニング現象防止および透磁 率上昇防止のため，抽出温度 $1150{ }^{\circ} \mathrm{C}$ の低温加熱を行な った。

(2)圧延条件 Fig.5に示す高Mn鋼の変形抵抗を考虑して 多パス压延を採用した。

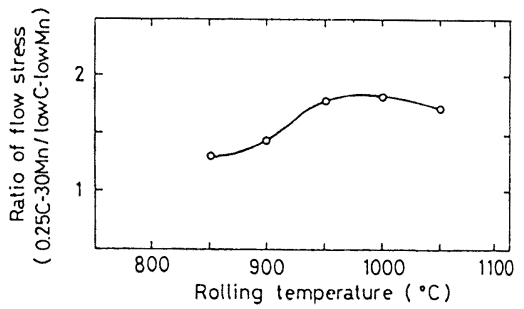

Fig. 5 Flow stress

\section{4. 製造結果}

上記条件にて製造した結果，従来の高 Mn非磁性鋼の品質改善をはかることができ，ステンレス鋼 SUS 304 以上の品質特性が得られた。

5. 結言 上記製造条件において，核融合炉等に使用される材料として，要求品質を十分満足できる $30 \% \mathrm{M} \mathrm{n}$ 非磁性 $\mathrm{H}$ 形鋼の 製造が可能となった。

参考文献

1)佐々机ら：川崎製鉄技報，13（1981）\%.3，381 
I 緒 言高 Mn 非磁性鋼は, 透磁率が低くかつ一般のオーステナイトステンレス鋼に比し安価で あるなどにより，非磁性材料として使用されることが多い。しかしてれらのオーステナイト鋼は一般 に固溶化ままでは耐力が低いため，冷間加工して強化される場合がある。冷間加工する場合透磁率の 変動が懸念され，本研究では $\mathrm{Mn} \cdot \mathrm{Cr} \cdot \mathrm{N}$ 系オーステナイト鋼を用い，制御圧延により压延ままでの強 化をはかった。同時に透磁率等も調査し，若干の知見を得たので報告する。

II 実験方法

Table 1 亿供試鋼の化学成分を示す。いずれも $\mathrm{Mn}$. Table 1. Chemical Composition (wt\%) $\mathrm{Cr} \cdot \mathrm{N}$ 系ベースの高 $\mathrm{Mn}$ 非磁性鋼であり, $200 \mathrm{~kg}$ 高周波 溶解炉を用いて溶製後，50t の板厚に鍛伸した。压延 は 7 パスにより $15 \mathrm{t}$ の板厚に仕上げた。加熱温度は1200 ${ }^{\circ} \mathrm{C}$ であり，パス間の時間待ちにより仕上温度を 800

\begin{tabular}{|c|c|c|c|c|c|c|c|c|}
\hline Stee 1 & C & Si & Mn & Cr & Ni & Mo & Nb & N \\
\hline K 1 & 0.19 & 0.25 & 16.17 & 17.04 & 1.76 & - & - & 0.356 \\
\hline K 2 & 0.05 & 0.22 & 15.25 & 16.63 & 1.56 & - & - & 0.333 \\
\hline K 3 & 0.19 & 0.18 & 15.46 & 16.81 & 1.54 & - & - & 0.124 \\
\hline K 4 & 0.20 & 0.23 & 15.51 & 16.58 & 1.52 & - & 0.24 & 0.117 \\
\hline K 5 & 0.19 & 0.24 & 15.30 & 16.66 & 1.52 & 0.49 & - & 0.120 \\
\hline
\end{tabular}
$1100^{\circ} \mathrm{C}$ に調整した。この压延材より試験片を採取し, 機械的性質, 透磁率, ミクロ組織等を調査した。

III 実 験 結果

(1) 低温仕上により, 耐力の向上がはかれ， $\mathrm{K} 1$ 鋼では $1000^{\circ} \mathrm{C}$ 仕 上により $75 \mathrm{~kg} \mathrm{f} / \mathrm{mnn}$ 級の耐力を得た (Fig. 1 )。但し圧延後の冷 却速度が遅くなると, 勒性の劣化が著しい。

(2) 耐力の向上には， Nの効果が大きく，本供試鋼レベルの Nb・ Moでは, その効果は軽微である(Fig. 1, 2)。

(3) $1200^{\circ} \mathrm{C}$ 溶体化処理材では, 耐力は $50 \mathrm{~kg} \mathrm{f} / \mathrm{mm}$ にも満たず，低 温仕上による強化は，著しく大きい(Fig. 2)。

(4) $\mathrm{Nb} \cdot \mathrm{M}_{0}$ の添加は, 仕上温度により透磁率の変動をきたし， 低透磁率の観点からは好ましくない（Fig. 3)。

(5) $\mathrm{Mn} \cdot \mathrm{Cr} \cdot \mathrm{N}$ 系非磁性鋼は， $\mu<1.01$ の非常に安定した非磁性 を示した。

(6) さらに, $\mathrm{Mn} \cdot \mathrm{Cr} \cdot \mathrm{N}$ 系非磁性鋼は, 冷間加 エをしてもその透磁率 の変動はほとんどない。 NV まとめ

高 $\mathrm{Mn}$ 非磁性鋼の耐力 向上のために，冷間・温 間加工せずとも，その圧 延条件と成分調整により， $70 \mathrm{~kg} f / \mathrm{mm}$ 級の耐力を得 るととが判明した。

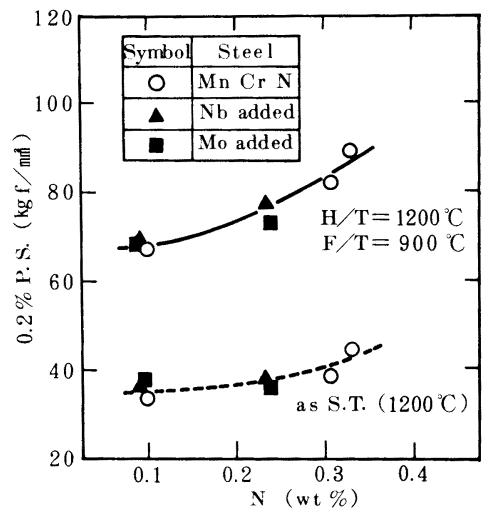

Fig. 2 Effect of $\mathrm{N}$ content on $0.2 \%$ Proof Stress.

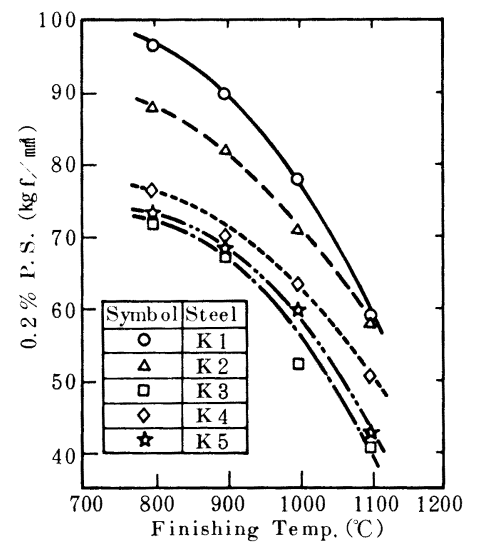

Fig. 1 Relation between $0.2 \%$ Proof Stress and Finishing Temperature.

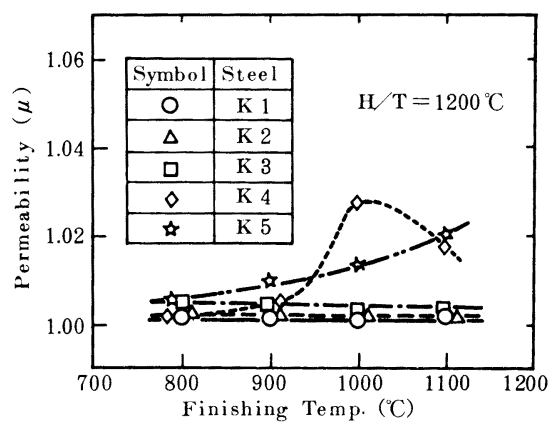

Fig. 3 Relation between Permeability and Finishing Temperature. 